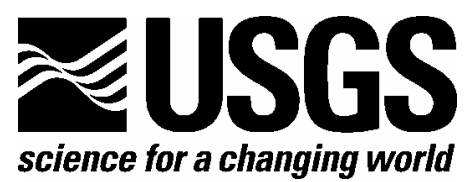

\title{
Science and Management in the Hanalei Watershed: A Trans-Disciplinary Approach
}

Proceedings from the Hanalei Watershed Workshop

February 21-22, 2007

Princeville, $\mathrm{HI}$

Edited by Michael E. Field, Carl J. Berg, and Susan A. Cochran

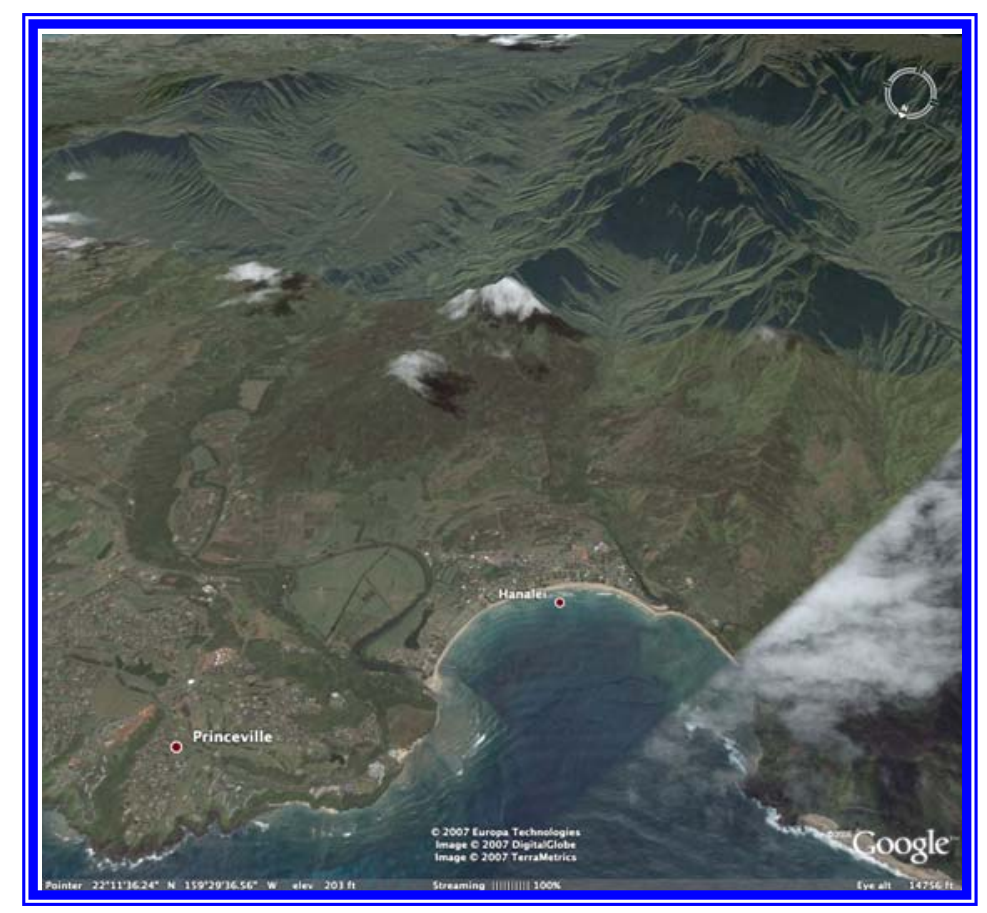

Open-File Report 2007-1219

U.S. Department of the Interior

U.S. Geological Survey 


\section{U.S. Department of the Interior DIRK KEMPTHORNE, Secretary}

\section{U.S. Geological Survey \\ Mark D. Myers, Director}

U.S. Geological Survey, Reston, Virginia 2007

Revised and reprinted: 2007

For product and ordering information:

World Wide Web: http://www.usgs.gov/pubprod

Telephone: 1-888-ASK-USGS

For more information on the USGS - the Federal source for science about the Earth, its natural and living resources, natural hazards, and the environment:

World Wide Web: http://www.usgs.gov

Telephone: 1-888-ASK-USGS

Suggested citation:

Field, M.E., Berg, C.J., and Cochran, S.A. (eds.), 2007, Science and Management in the Hanalei Watershed: A Trans-Disciplinary Approach; Proceedings from the Hanalei Watershed Workshop: USGS Open-File Report 2007-1219, 87 p.

Any use of trade, product, or firm names is for descriptive purposes only and does not imply endorsement by the U.S. Government.

Although this report is in the public domain, permission must be secured from the individual copyright owners to reproduce any copyrighted material contained within this report. 


\section{Contents}

Acknowledgements ……............................................................................................................

Introduction ......................................................................................................................................vii

Mike Field and Carl Berg, Workshop Conveners

Coral Disease in Hanalei Bay ......................................................................................................... Greta Aeby

History of Water Quality Studies in the Hanalei Bay Watershed ....................................................2 Carl Berg

Tracing Mobile Sediments in the Hanalei Watershed and Bay System: A Geochemical

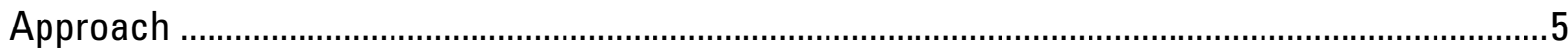

Michael Bothner, Sandra Baldwin, Michael Casso, Amy Draut, Richard Rendigs, Richard

Reynolds, and Renee Takesue

Spatio-Temporal Patterns in Coral Cover and Coral Settlement on an Exposed Shoreline in

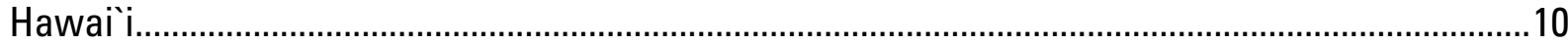

Eric Brown and Alan Friedlander

Sediment Porewater Toxicity Study in Hanalei Bay, Kaua i 13 Scott Carr and Marion Nipper

Investigating the Use of Remote Sensing for Watershed Landscape Analyses with Applications to Water Erosion Vulnerability and Sedimentation in Hawai i: Hanalei, Kaua $\mathrm{i}$ 16

Pat Chavez, Jo-Ann Isbrecht, Rian Bogle, and Miguel Velasco

Distribution of mud in Hanalei Bay, Kaua i: June vs. September 2006. 18 Susan Cochran, Mike Field, and Curt Storlazzi

Seasonal Flood Deposits in Hanalei Bay, Kaua 'i, $\mathrm{HI}$ .22 Amy Draut, Mike Field, Mike Bothner, Susan Cochran, Michael Casso, Sandy Baldwin, Richard Reynolds, Josh Logan, and Curt Storlazzi

Riparian Composition and Function in a Small Watershed in Hanalei, Hawai i . .28 Carl Evensen and Guy Ragosta

Evaluation of a Non-Point Source Pollution Model, AnnAGNPS, in Hanalei Watershed, Kaua ì.

Ali Fares 
Photographic Time Series of Sedimentation Near the Wall, Hanalei Bay, Kaua i, Summers of 2005 and 2006

Mike Field, Hank Chezar, and Curt Storlazzi

Resistance and Resilience of a Hawaiian Coral Reef Fish Assemblage to Dynamic Natural Conditions: Hanalei Bay, Kaua 'i - 1993 to 2005.

Alan Friedlander and Eric Brown

Developing Tools for Assessing Land Based-Contamination Impacts in Corals. Laetitia Hédouin and Ruth Gates

Hydrodynamic Modeling of Hanalei Bay

Ron Hoeke and Curt Storlazzi

Mapping Plant Species and Communities in the Hanalei Watershed Jim Jacobi and Stephen Ambagis

Impact of Sediment, Storm Waves and Storm Floods on Hawaiian Reef Communities .45 Paul Jokiel

Submarine Groundwater Discharge in Hanalei Bay: Impacts on Coastal Water Quality .46 Karen Knee, Blythe Layton, Alexandria Boehm, Joseph Street, Carl Berg, and Adina Paytan

Hanalei Bioassessment Survey Linda Koch

USDA Natural Resources Conservation Service Assistance to Hanalei .50 Dudley Kubo

Options for the Disposal of Wastewater Effluent in Hanalei, Hawai i . .52 West Marrin

Climate Data Input to Modeling the Hanalei Watershed .54 Daniel Moore

Survey of Chemical Contaminants in the Hanalei River, Kaua 'i, Hawai i, 2001 .57 Carl Orazio, Thomas May, Robert Gale, John Meadows, William Brumbaugh, Kathy Echols, William Steiner, and Carl Berg

Soil Sampling for Cesium-137 and Observations of Streambank Erosion in the Hanalei River Watershed . .59 Paul Pedone 
Water Quality Regulation in the Hanalei Bay Watershed

David Penn, Amy King, Andrew Parker, John Craig, and Sen Bai

Magnetic Study of Sediment in Hanalei Bay and the Hanalei River Watershed: Contribution to Understanding Sources and Transport of Terrigenous Sediment 64 Richard Reynolds, Michael Bothner, Carl Berg, Amy Draut, and Harland Goldstein

Geomorphic Assessment of the Hanalei Stream Network Including Preliminary Hydraulic Geometry Analysis Results Matt Rosener

Applying the Science: Taking Steps to Improve Water Quality and Coral Reef Communities.....71 Hudson Slay, Dave Penn, Katherine Chaston, Wendy Wiltse, and Audrey Shileikis

Summary of the 2006 Update to the Soil Survey for Hanalei Watershed .74 Chris Smith and Katina Hanson

In Situ Measurements of Coastal Circulation and Sediment Dynamics in Hanalei Bay, Kaua ì. .77

Curt Storlazzi, Kathy Presto, Josh Logan, and Mike Field

Streamflow and Suspended Sediment Load in the Hanalei River . .80 Gordon Tribble and Barry Hill

Appendix 1. Agenda for the Hanalei Watershed Workshop .83

Appendix 2. List of Workshop Contributors .85 


\section{Acknowledgements}

The communities of Hanalei Bay and northern Kaua`i have been overwhelmingly supportive of our research studies in the watershed and the bay, and we very much appreciate and thank them for their support. Many of our studies could not have been conducted without their assistance. In particular, we wish to acknowledge the members of the Hanalei Watershed Hui for their major contribution of bringing together scientists and managers from a diversity of backgrounds and disciplines; it was indeed the precise approach that was needed to understand the complex Hanalei system. We thank the Princeville Resort for making it possible to host this workshop in their hotel on the doorstep of Hanalei Bay, a remarkable venue for a remarkable watershed. The success of the workshop results from the efforts of many, and we wish to acknowledge in particular the masterful organizational skills of Kathleen Donahue. The abstracts in this volume benefited from the careful and knowledgeable reviews of David Rubin of the U.S. Geological Survey in Santa Cruz, CA, and Katherine Chaston of the University of Hawai i at Manoa, and we thanks them for their time and thoughts. A significant portion of this workshop, along with publication of this abstract volume, was made possible by the Coastal and Marine Geology Program of the U.S. Geological Survey. 


\section{Introduction}

\section{Mike Field and Carl Berg, Workshop Conveners}

The results of recent studies in the Hanalei watershed are impressive, both in content and breadth. Funded, directed, and/or conducted by investigators from many disciplines from local organizations (the Hanalei Watershed Hui), the University of Hawai i, the State of Hawai i (Department of Health, Department of Land and Natural Resources), and Federal organizations (U.S. Department of Agriculture, U.S. Geological Survey, Environmental Protection Agency, National Oceanic and Atmospheric Agency), their sum total have contributed markedly to our understanding of processes in the watershed. There has been an overwhelming amount of information that has been collected in the Hanalei Bay Watershed-from Mt. Waialeale to the far reefs-in just the past 5 years. This workshop was initiated to document our collective understanding, better integrate our results, and identify the salient issues that remain to be studied.

To better understand the processes and impacts to the terrestrial and marine ecosystems, we fashioned a series of questions that sought to focus the knowledge and expertise of the workshop participants on providing understanding of the interplay of processes in the watershed. The topics and daughter questions that the group undertook are as follows:

\section{- How sediment is generated in the watershed}

- What is the importance and relative contributions of landslides and stream banks as sediment sources, and are the amounts changing in frequency?

- Do invasive plants and feral ungulates (such as pigs) play a role in the amount of sediment released by landslides or overland flow?

- Is sediment in storage in the valley an important historic source?

- Where is most of the sediment coming from in the watershed?

- How sediment is transported in the watershed

- What rainfall or streamflow thresholds generate large sediment fluxes?

- What transport processes dominate in the valley, and where (debris flows vs. channelized flows vs. overland flow)?

- What are representative bank erosion rates, and what material is entrained? 
- Deposition of sediment in the lower watershed

- Have historical (and possibly archaeological) alterations to the banks of the Hanalei River reduced overbank flow and fine sediment deposition during floods?

- What are historic deposition rates, and are they comparable to Holocene and Pleistocene rates?

- Has the delta location varied over the Holocene, and how might this affect the reef system?

- Deposition of sediment in the bay and beyond

- What are the pathways of sediment through and within the bay?

- What is the residence time of flood sediment in the bay?

- What are the major controls on transport and residence time within the bay?

- Flow of nutrients and pathogens via groundwater and surface flow

- Is groundwater an important source of nutrients to the bay? Of pathogens?

- Are there particular "hot spots" of groundwater discharge along the shoreline and/or within the bay?

- Are there particular "hot spots" of nutrients/pollutants, and do we know the source?

- What are the circulation patterns and residence times of pathogens, pollutants and nutrients in the bay?

- How terrestrial and aquatic ecosystems have been affected

- What is the relative health of the Hanalei River ecosystem?

- What is the relative health of the Hanalei Bay coral and fish populations?

- Have coral recruitment rates changed in recent years, and if so, do we know the cause?

- What management actions are needed to improve water quality and reduce pollution threats to corals?

- How can we document our present state of knowledge for application to management?

- What science questions need to be addressed for improved decision-making and resource management?

The participants in this workshop were directed to address possible sources of these and other pollutants, their effects on the environment, and possible management actions to reduce levels of pollution and pollutant loads. As this collection of abstracts illustrates, they did an amazing job. The goal is now to determine what further research and collaborations are necessary to meet information needs, and how to use this information in making policy decisions for water quality improvements for the watershed. 


\title{
Coral Disease in Hanalei Bay
}

\author{
Greta Aeby'
}

Coral disease has contributed to the serious decline of reefs in the Western Atlantic and is also emerging as a problem in the Indo-Pacific. In 2004, baseline coral disease surveys were initiated in the main Hawaiian Islands and as part of this effort, coral disease assessment was added to the Coral Reef Assessment and Monitoring Program (CRAMP) protocol at 3 sites within Hanalei Bay. Corals were examined for signs of disease along established belt transects for a total of $250 \mathrm{~m}^{2}$ of reef surveyed. Corals with lesions were described, photographed and samples taken for follow-up histopathological analysis. Signs of disease were found at all three sites with an average of 0.027 diseased colonies $/ \mathrm{m}^{2}$ found. Montipora was the dominant coral on the reefs and two montiporid diseases were documented including Montipora white syndrome and an unusual Montipora banded tissue loss disease, which has not been found elsewhere in the Hawaiian archipelago. Heavy sediment stress was evident on the reefs, which might explain the occurrence of the unusual disease. Future studies are planned to more fully investigate disease within Hanalei Bay.

\footnotetext{
${ }^{1}$ Hawai i Institute of Marine Biology, PO Box 1346, Kane`ohe, HI 96744
} 


\title{
History of Water Quality Studies in the Hanalei Bay Watershed
}

\author{
Carl Berg
}

In 1998 the Hanalei community came together through the designation of the Hanalei River as an American Heritage River, and formed the Hanalei Heritage River Hui. The Hui held a series of community meetings and developed a Watershed Action Plan. A prime component of that plan was the concern of the community that the waters of Hanalei River and Hanalei Bay were polluted and that something should be done to make the waters clean (fishable and swimmable under the Clean Water Act). Actions were taken to begin volunteer monitoring of the streams, river and bay, and, under the auspices of the American Heritage Rivers Initiative, to bring Federal partners together to assess pollution in these waters, its causes, and its effect on the stream, estuarine, and coral reef biological communities. The U.S. Department of Agriculture's Natural Resources Conservation Service (NRCS) undertook the development of the Agricultural Non-Point Source (AGNPS) computer model of erosion and sedimentation in the upper watershed. The Hanalei Heritage River Hui incorporated as the non-profit Hanalei Watershed Hui (HWH), applied for, and was awarded in 2003 one of the U.S. Environmental Protection Agency's (EPA's) first Targeted Watershed Initiative grants. With this, and additional funding, the HWH partnered with various Federal and University scientists in research and mitigation programs.

Earlier studies of Hanalei Watershed waters by the Hawaii State Department of Health (DOH) had shown the waters to be water-quality limited (polluted). The DOH data were supplemented by data collected by volunteers and staff of the $\mathrm{HWH}$ and incorporated in the DOH 2004 303(d) list of impaired waters. Hanalei Bay and Hanalei, Wai oli, Waipa, and Waikoko estuaries were all variously listed as impaired for turbidity and/or Enterococcus bacteria, an indicator of fecal contamination. The estuaries were given a high priority rating and a Total Maximum Daily Load (TMDL) study was recommended for the Hanalei Estuary. This study was undertaken with funding from the EPA, is nearly completed.

As part of the Hanalei Targeted Watershed Initiative, the HWH staff undertook a study of the quality of the waters of Hanalei Bay Watershed and presented these data to the DOH for the next round of water quality limited designations and for the TMDL study. Briefly, HWH believes that the waters do not meet DOH standards for nutrients. Values in red in table 1 exceed either geometric mean criteria, or criteria that samples exceeded a threshold level greater than $5 \%$ or $10 \%$ of the time. The U.S. Geological Survey (USGS) and Ducks Unlimited (DU) Pond sites are in the freshwater, middle reach of the Hanalei River, while the others are in the estuaries of the river or streams. All of

${ }^{2}$ Hanalei Watershed Hui, PO Box 1285, Hanalei, HI 96714 
the estuaries exceed DOH standards for turbidity (table 2) and the USGS and DU riverine sites exceed standards in the dry season (table 3). Enterococcus geometric mean values for Hanalei Bay estuaries and water at the Hanalei Pier exceed DOH and EPA standards (tables 4). Values for beach waters at Hanalei Pavilion and Pinetrees exceed DOH standards (7 cfu/100 ml) but not EPA standards (34 cfu/100 ml).

Table 1. Comparison of nutrient data from 2003 to 2005. Values indicate the geometric mean (ug/L, or micrograms per liter) of 24 monthly samples (TN = total nitrogen; $\mathrm{NH}_{4}=$ ammonium nitrogen; $\mathrm{NO}_{3}+\mathrm{NO}_{2}=$ nitrate and nitrite nitrogen; $\mathrm{TP}=$ total phosphorous; and $\mathrm{PO}_{4}=$ orthophosphate phosphorous).

\begin{tabular}{|c|r|r|r|r|r|r|r|}
\hline & \multicolumn{1}{|c|}{ USGS } & \multicolumn{1}{c|}{ DU } & \multicolumn{1}{c|}{ Hanalei } & \multicolumn{1}{c|}{ Waioli } & \multicolumn{1}{c|}{ Waipa } & Waikoko & Criteria \\
\hline TN & 79.7 & 110.5 & 143.6 & 139.2 & 116.3 & 275.8 & 200 \\
\hline $\mathbf{N H}_{4}$ & 3.8 & 8.4 & 24.3 & 24.3 & 16.9 & 105.4 & 6 \\
\hline $\mathbf{N O}_{3}+\mathbf{N O}_{2}$ & 3.4 & 3.6 & 18.3 & 36.7 & 8.3 & 45.5 & 8 \\
\hline TP & 20.6 & 26.2 & 32.3 & 29.8 & 25.3 & 51.4 & 25 \\
\hline P04 & 3.1 & 4.8 & 7.3 & 7.9 & 3.3 & 13.4 & na \\
\hline
\end{tabular}

Table 2. Sediment data from 2003 to 2005 for various Hanalei estuaries. Values indicate the geometric mean of 18 monthly samples. All of the estuaries entering Hanalei Bay exceed DOH water quality criteria for NTU (NTU = nephelometric turbidity units; TSS = total suspended solids).

\begin{tabular}{|c|c|c|c|c|c|}
\hline & Hanalei & Waioli & Waipa & Waikoko & Criteria \\
\hline NTU & 10.3 & 6.5 & 8.2 & 19.3 & 1.5 \\
\hline TSS (mg/L) & 12.7 & 6.9 & 8.8 & 18.0 & na \\
\hline
\end{tabular}

Table 3. Sediment data from 2003 to 2005 for Hanalei River locations. Values indicate the geometric mean of 18 monthly samples. Hanalei River at USGS and DU sites exceed DOH water quality criteria for NTU for dry seasons. (NTU are nephelometric turbidity units, and TSS refers to total suspended solids.)

\begin{tabular}{|c|r|r|r|r|}
\hline & \multicolumn{1}{|c|}{ USGS } & \multicolumn{1}{c|}{ DU } & \multicolumn{1}{c|}{ Mouth } & \% increase \\
\hline NTU & 4.7 & 8.5 & 10.3 & $119.1 \%$ \\
& & & & \\
\hline TSS (mg/L) & 5.4 & 8.0 & 12.7 & $135.2 \%$ \\
\hline
\end{tabular}


Table 4. Comparison of Enterococcus values in mpn/100 ml (most probable number per 100 milliliters) from 2003 to 2005.

\begin{tabular}{|c|c|c|c|c|c|c|c|c|c|c|c|c|c|c|}
\hline Location & \multirow{2}{*}{\multicolumn{2}{|c|}{$\begin{array}{l}\text { H. Pier } \\
\text { Beach }\end{array}$}} & \multirow{2}{*}{\multicolumn{2}{|c|}{$\begin{array}{l}\text { H. Pavilion } \\
\text { Beach }\end{array}$}} & \multirow{2}{*}{\multicolumn{2}{|c|}{$\begin{array}{c}\text { Pinetrees } \\
\text { Beach } \\
\end{array}$}} & \multirow{2}{*}{\multicolumn{2}{|c|}{$\begin{array}{l}\text { Weke } \\
\text { Estuary }\end{array}$}} & \multirow{2}{*}{\multicolumn{2}{|c|}{$\begin{array}{l}\text { Waioli } \\
\text { Estuary }\end{array}$}} & \multirow{2}{*}{\multicolumn{2}{|c|}{$\begin{array}{l}\text { Waipa } \\
\text { Estuary }\end{array}$}} & \multirow{2}{*}{\multicolumn{2}{|c|}{$\begin{array}{l}\text { Waikoko } \\
\text { Estuary }\end{array}$}} \\
\hline Type & & & & & & & & & & & & & & \\
\hline Total Yearly & Enterococcus & $0 / 00$ & Enterococcus & $0 / 00$ & Enterococcus & $0 / 00$ & Enterococcus & $0 / 00$ & Enterococcus & 0 & Enterococcus & \begin{tabular}{|l|l|}
$0 / 00$ \\
\end{tabular} & Enterococcus & $0 / 00$ \\
\hline Count & 90 & 99 & 90 & 99 & 90 & 99 & 89 & 100 & 90 & 101 & 89 & 100 & 89 & 100 \\
\hline & & & & & & & & & & & & & & \\
\hline Geometric Mear & 77.2 & & 22.0 & & 21.5 & & 182.2 & & 389.9 & & 373.1 & & 89.0 & \\
\hline Max & 15,531 & & 2,489 & & 2,359 & & 7,270 & & 24,196 & & 24,196 & & 695 & \\
\hline Min & $<10$ & & $<10$ & & $<10$ & & $<10$ & & 41 & & 20 & & 24196 & \\
\hline 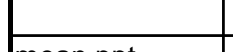 & & & & & & & & & & & & & & \\
\hline mean ppt & & 28 & & |33.3 & & 33.5 & & \begin{tabular}{|l|}
3.7 \\
\end{tabular} & & 1.63 & & 3.09 & & 5.28 \\
\hline
\end{tabular}




\title{
Tracing Mobile Sediments in the Hanalei Watershed and Bay System:
}

\section{A Geochemical Approach}

\author{
Michael Bothner', Sandra Baldwin', Michael Casso', Amy Draut ${ }^{2}$, Richard Rendigs' ${ }^{1}$, Richard \\ Reynolds ${ }^{3}$, and Renee Takesue ${ }^{2}$
}

Knowledge of the source, composition, and fate of sediments transported from the Hanalei Watershed to the bay and beyond are necessary to predict impacts on coastal ecology. This information is required to evaluate the need for preventative or restorative measures.

In order to identify tracers of sediments transported from the watershed to Hanalei Bay, we have measured three geochemical parameters: radioactive isotope activities, metal concentrations, and magnetic properties. The radioactive isotopes ${ }^{7} \mathrm{Be}$ (53-day half-life) and ${ }^{137} \mathrm{Cs}$ (30- year half-life) are present in the system largely from atmospheric deposition on land that imprints surface sediment in the watershed. Suspended sediment in the river mobilized by floodwaters carries an isotopic signature that is observed in suspended matter and in flood deposits in the bay. The isotopes also provide information about the timing of past flood events recorded in sediment cores. ${ }^{210} \mathrm{~Pb}_{\mathrm{ex}}{ }^{4}$ (22-year half- life) has both atmospheric and marine sources and contributes supporting information about these processes.

Metal concentrations and concentration ratios are being determined by multi-element ICP-MS techniques to characterize the chemical composition of sediments in different components of the system, and to identify common chemical relationships between sediment sources and sinks. The metal analyses also evaluate present concentrations of potentially toxic metals and provide a baseline for future change. The third geochemical parameter consists of magnetic properties of sediments throughout this system. These properties, summarized in the abstract by Reynolds and others (this vol., p. 63), show promise in characterizing sediment from different upland regions of the watershed, as well as providing a traceable signature from river suspended matter to sediments in the bay.

Samples of suspended sediment offshore of the Hanalei River were collected with a time series sediment trap (fig. 1) deployed $400 \mathrm{~m}$ west of the river mouth (Trap W, $1.3 \mathrm{~m}$ above bottom at $10 \mathrm{~m}$ water depth) from June to September 2006. Figure 2 shows that the time-series sediment trap collected material typically at the rate of about $50 \mathrm{~g} / \mathrm{m}^{2} /$ day during 4day intervals until the flood of August 7, 2006, when the trap collection rate increased to more

\footnotetext{
${ }^{1}$ USGS Woods Hole Science Center, 384 Woods Hole Road, Woods Hole, MA 02543

${ }^{2}$ USGS Pacific Science Center, 400 Natural Bridges Drive, Santa Cruz, CA 95060

${ }^{3}$ USGS, PO Box 25046, Denver Federal Center, MS980, Denver, CO 80225

${ }^{4}$ Excess lead-210 $\left({ }^{210} \mathrm{~Pb}_{\mathrm{ex}}\right)$ is the total ${ }^{210} \mathrm{~Pb}$ activity level minus the level supported by parent isotopes in the uranium decay series.
} 
than $520 \mathrm{~g} / \mathrm{m}^{2} /$ day, plugging the trap funnel. An identical trap at the South Central site (Trap $\mathrm{SC}), 800 \mathrm{~m}$ southwest of the river mouth, did not show an increase in collection rate at the time of this flood event, indicating that the flood-derived plume did not markedly increase the sediment collection rate at this location. Measurements of bottom stress and turbidity by Storlazzi and others (this vol., p. 76) indicate that the high collection rates at the $\mathrm{W}$ site are related to river discharge and the rates at the SC site are linked to bottom stress from waveinduced currents. Trap collection rates are not a measure of net sediment accumulation on the sea floor.

The activity of radioisotopes (fig. 3) in samples from Trap W near the river mouth show minor changes with time until the flood of August 7. Material collected as the flood entered the bay had higher ${ }^{7} \mathrm{Be}$ and ${ }^{137} \mathrm{Cs}$ and lower ${ }^{210} \mathrm{~Pb}_{\text {ex }}$ activities than in samples prior to the flood. The activities in the trapped flood material were similar to activities in a single sample of suspended sediment from the river collected on September 6, and provide evidence of the direct linkage from the river to the sediment trap at site $\mathrm{W}$. The elevated ${ }^{7} \mathrm{Be}$ and ${ }^{137} \mathrm{Cs}$ activities in surface sediments of cores collected from the "Black Hole" near site W extend the linkage from the river to the major depositional area in the bay. This conclusion assumes that the river sample collected during moderate flow (about $7 \mathrm{~m}^{3} / \mathrm{s}$ ) on September 6 reflects the isotopic signature during the greater flood of August $7\left(46 \mathrm{~m}^{3} / \mathrm{s}\right)$.

It is of interest to note that the ${ }^{210} \mathrm{~Pb}_{\mathrm{ex}}$ activities in flood deposits of the Black Hole are significantly higher than in the river suspended matter or in trapped flood material. The higher values are attributed to scavenging of dissolved ${ }^{210} \mathrm{~Pb}_{\text {ex }}$ that is produced from decay of ${ }^{226} \mathrm{Ra}$ dissolved in coastal seawater. The scavenging process illustrated by ${ }^{210} \mathrm{~Pb}_{\mathrm{ex}}$ could be expected to operate on sediment-reactive contaminants that are added to the coastal ocean from accidental spills from ships, runoff, or from the atmosphere. It outlines a mechanism by which dissolved contaminants could be introduced to depositional areas of Hanalei Bay.

The scavenging process is also illustrated by the distributions of radioactive isotopes in time series trap samples (fig. 4) from the site $800 \mathrm{~m}$ south west of the river mouth. Samples in this trap had the highest ${ }^{210} \mathrm{~Pb}_{\mathrm{ex}}$ among all the samples analyzed in this program. The activities of ${ }^{7} \mathrm{Be}$ and ${ }^{137} \mathrm{Cs}$ generally increase during the deployment with higher and variable activities after the August 7 flood. The highest activities of all three isotopes occur during the late August - early September time frame when bottom stress and trap collection rates were low. Material collected then might have much smaller grain size (higher surface area) and/or higher organic carbon that could account for higher scavenging of all the isotopes. Sediment texture and organic carbon content of trapped sediment have not yet been determined.

A preliminary analysis of the metal data indicates that the $\mathrm{Ba} / \mathrm{Al}$ ratio is a good tracer of terrigenous sediment. This ratio is constant in both time-series trap sediments until the flood of August 7 (fig. 5). Near the river mouth, flood samples have 50\% higher Ba/Al than preflood samples. At the South Central site, the flood and post-flood samples have $19 \%$ higher $\mathrm{Ba} / \mathrm{Al}$ ratio than pre-flood values, interpreted to suggest a slight influence from flood-derived sediment at this location. Differences in $\mathrm{Ba} / \mathrm{Al}$ ratio between the river suspended sample collected in September and trapped bay sediments (before and during the August flood) suggest different sediment provenance during floods of different intensity in the watershed. 
The magnetic properties provide additional tracking information in samples of suspended river sediment, in sediment trap samples from the August flood period, and in samples from flood layers recovered in cores. The parameters showing similarities among sediments in these transitional settings include the absolute and relative abundance of magnetite and hematite, and the magnetic grain size.

These geochemical tools are contributing to the understanding of linkages and timing of sediment events on land, in the river, and in the bay. More samples are needed to characterize the potential sediment sources in this watershed, and a sampling scheme should be in place to collect river suspended matter during major floods.

A
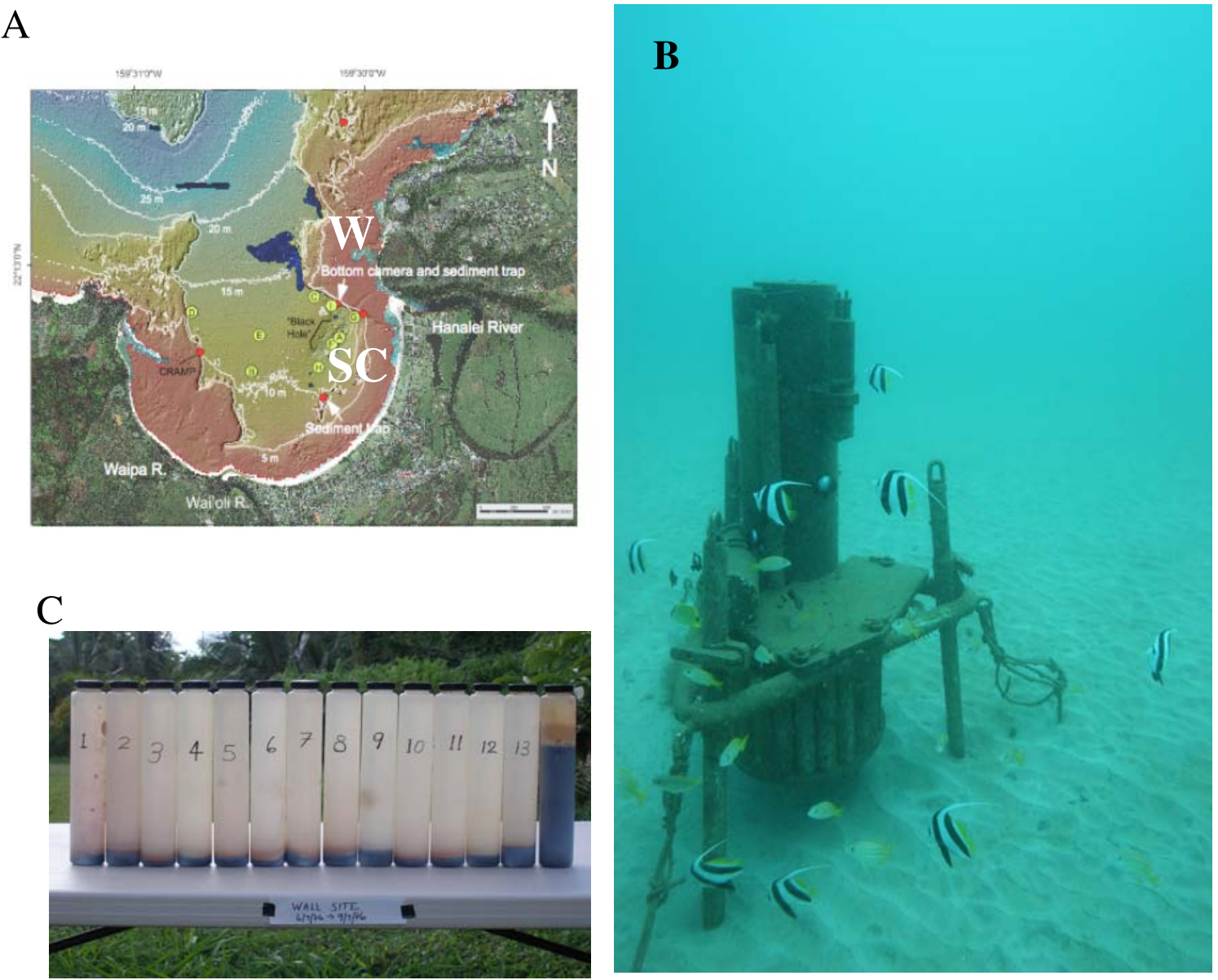

Figure 1. (A) Location of time series sediment traps W and SC in Hanalei Bay. $(B)$ Image of the deployed time series trap at site SC. Trap opening is $20 \mathrm{~cm}$ and is positioned $1.3 \mathrm{~m}$ above bottom. (C) Image of 14 of 21 sampling bottles from site $\mathrm{W}$ that contain trapped sediment from June 6, 2006 until the flood of August 7, 2006 plugged the trap while bottle 14 was in place. 


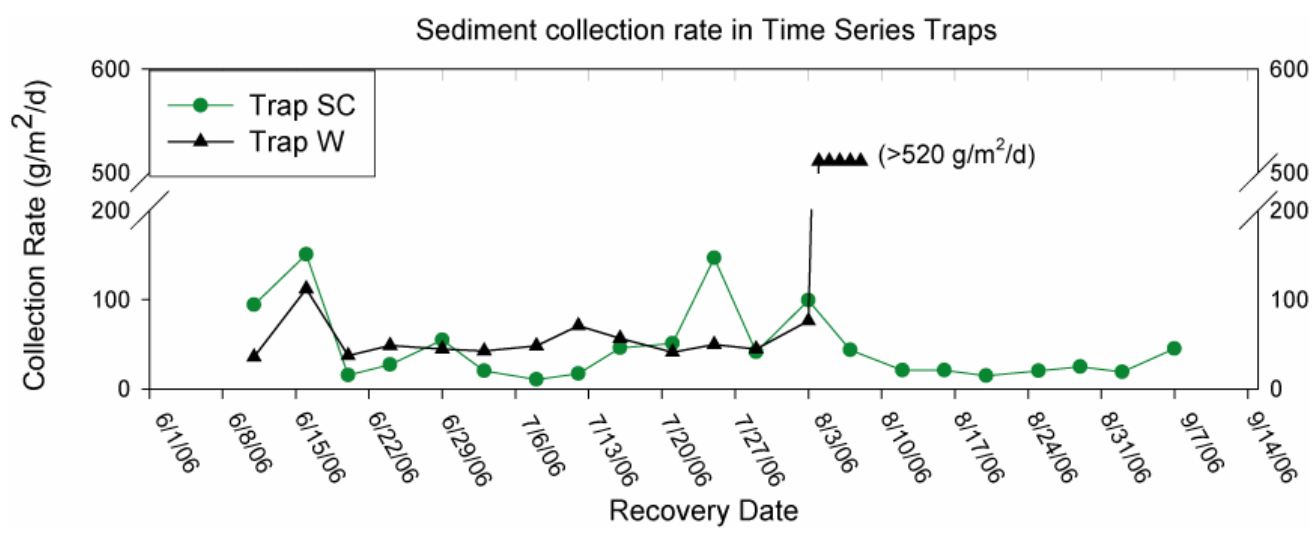

Figure 2. Sediment collection rate in time series sediment traps. Trap W is about $400 \mathrm{~m}$ west of the Hanalei River mouth. Trap SC is $800 \mathrm{~m}$ southwest of the river mouth. Trap W plugged during the flood of August 7, 2006.

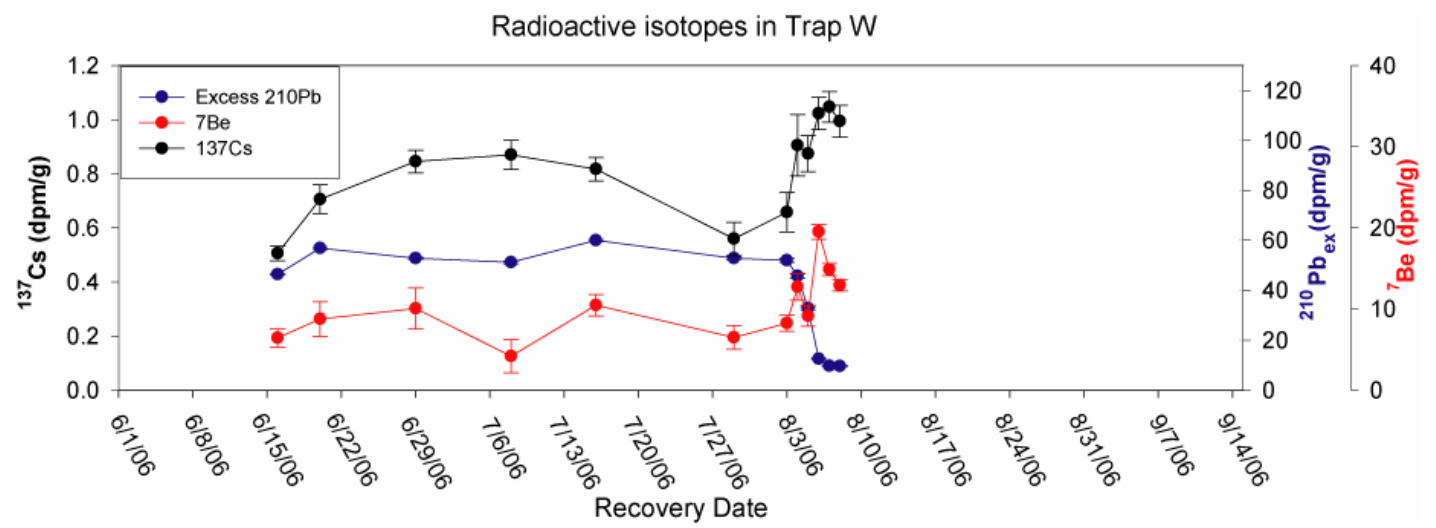

Figure 3. Activity of isotopes in time series Trap W. Activities in a sample of TSS and colloidal material from the Hanalei River (9.6.06) were: ${ }^{137} \mathrm{Cs}: 1.7$ and $3.2 \mathrm{dpm} / \mathrm{g} ;{ }^{7} \mathrm{Be}: 24$ and $36 \mathrm{dpm} / \mathrm{g} ;{ }^{210} \mathrm{~Pb}_{\mathrm{ex}}: 10$ and $19 \mathrm{dpm} / \mathrm{g}$ (where $\mathrm{dpm}=$ radiation counts in disintegrations per minute).

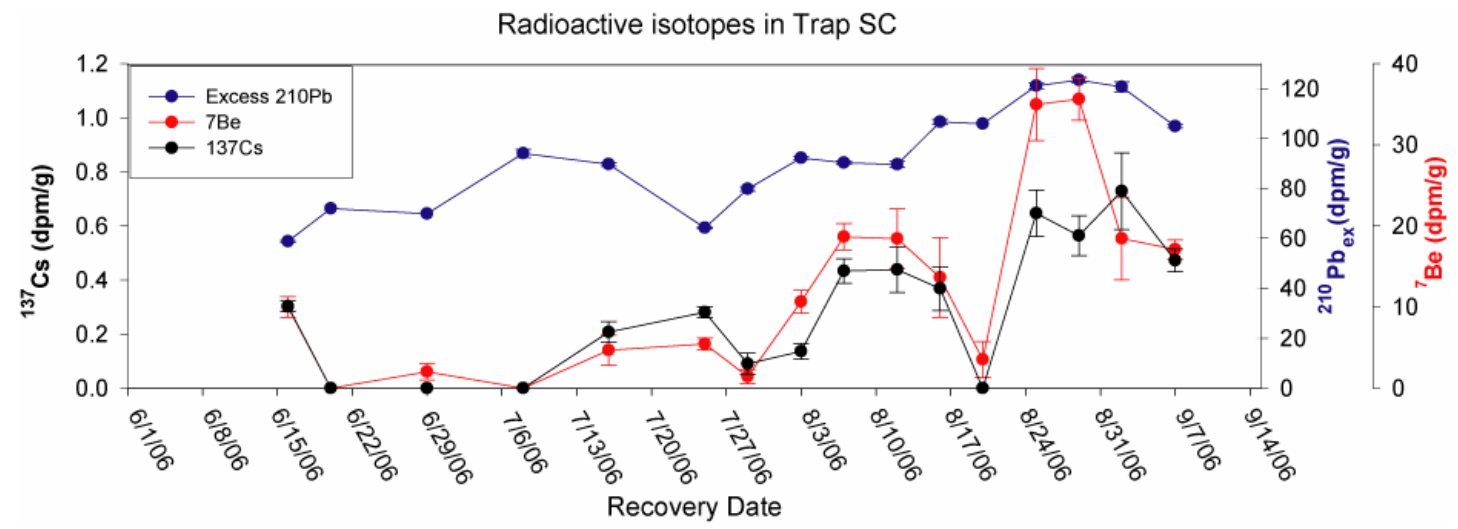

Figure 4. Activity of radioactive isotopes in time series Trap SC. 


\section{Ba/Al Ratio in Time Series Trap Samples}

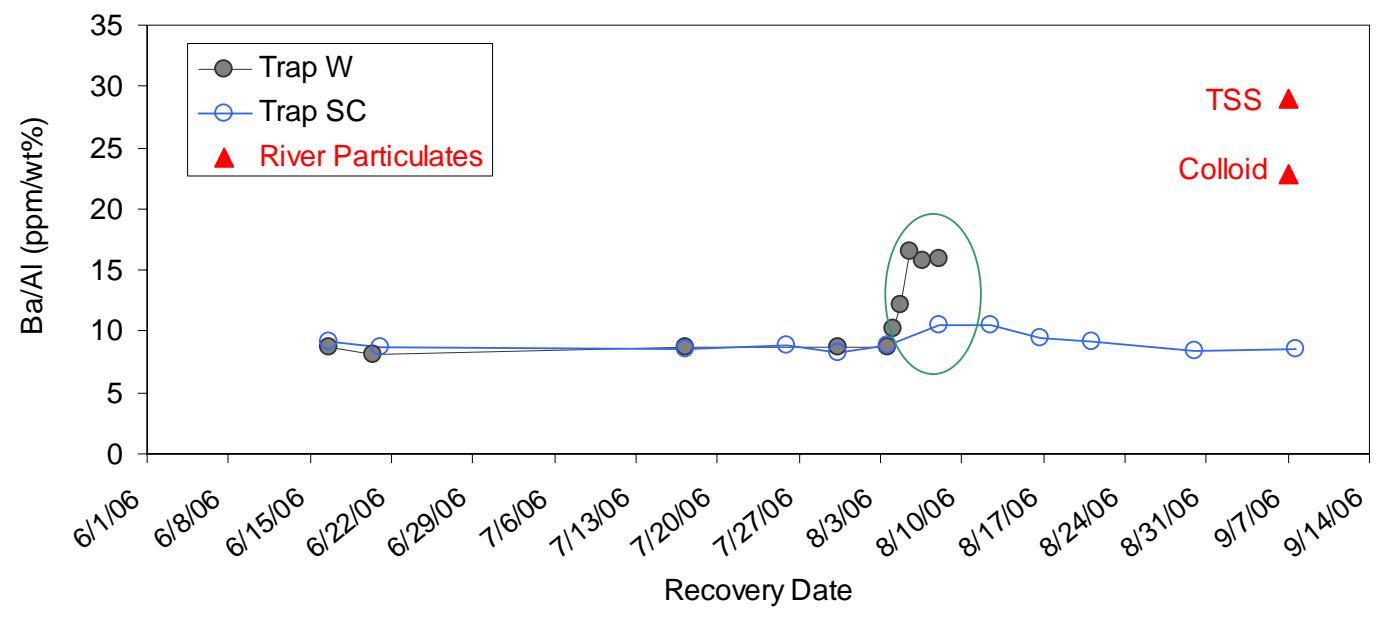

Figure 5. Variation of the barium to aluminum ratio in time-series trap samples from Hanalei Bay. Ba/Al ratios in river suspended matter (TSS) and the "colloidal" fraction are shown as red triangles. The green oval contains samples collected during the August flood period, which show a different composition than samples collected during June and July. 


\title{
Spatio-Temporal Patterns in Coral Cover and Coral Settlement on an
}

\section{Exposed Shoreline in Hawai i}

\author{
Eric Brown' and Alan Friedlander ${ }^{2,3}$
}

Hanalei Bay, Kaua $i$ is situated in a dynamic and relatively harsh environment that at times includes high wave energy, heavy fresh water influx, and high turbidity. Coral cover along 20 permanent transects was assessed using photoquadrats (1993), digital video transects (1999), and digital still photographs (2004, 2005). Random points were projected on the images to generate percent cover of substrate types. Around Hanalei Bay, overall coral cover was low (ca. 14\%) and dominated by encrusting forms adapted to high wave energy. Shallow sites with greater wave exposure had the lowest coral cover. Sites along edge habitats with greater protection from large surf had higher coral cover. The five most abundant coral species in 1993 were Montipora patula (7\%), M. capitata (2\%), Porites lobata (2\%), P. compressa (1\%), and Pocillopora meandrina (1\%). Average percent coral cover increased non-linearly in Hanalei Bay. Between 1993 and 1999 there was an increase of 5\% absolute (34\% relative) from $14 \%$ to $19 \%$. From 1999 to 2005 coral cover remained relatively stable. Much of the initial increase was attributed to Montipora patula, which increased in percent cover from $7 \%$ in 1993 to $11 \%$ in 2005. Species composition patterns remained similar during that time period.

Settlement plates were deployed and retrieved from 2003 to 2005 to estimate settlement of coral larvae during the annual spawning events. Coral settlement was higher in the outer bay than in the inner bay. Coral recruits were dominated by the genus Montipora that typically has high recruitment rates but low survival compared to other coral genera. Temporal patterns in coral settlement corresponded negatively to Hanalei river flow and wave activity. A similar larval settlement study conducted concurrently on a wave-exposed, north shore reef community at Moloka i had significantly lower larval settlement than what was documented at Hanalei Bay. Larval settlement around Hanalei Bay was also higher compared to other regions around the world and may help explain the increase in coral cover observed over the past decade. Temporal variability, artificial substrate type used, or observer biases, however, could all affect documented settlement patterns, therefore these patterns may not directly influence increases in coral cover.

\footnotetext{
${ }^{1}$ NPS, Kalaupapa National Historical Park, PO Box 222, Kalaupapa, HI 96742

${ }^{2}$ NOAA, National Ocean Service, National Centers for Coastal and Ocean Science, Biogeography Team

${ }^{3}$ The Oceanic Institute, 41-202 Kalanianaole Highway, Waimanalo, HI 96795
} 
Hanalei Bay is one of the few areas in Hawai $i$ that has shown an increase in live coral cover over the past decade. Natural factors such as large wave events are thought to be more important in structuring the coral reef community of Hanalei Bay than anthropogenic factors, and this may help to explain the trends observed in this study.

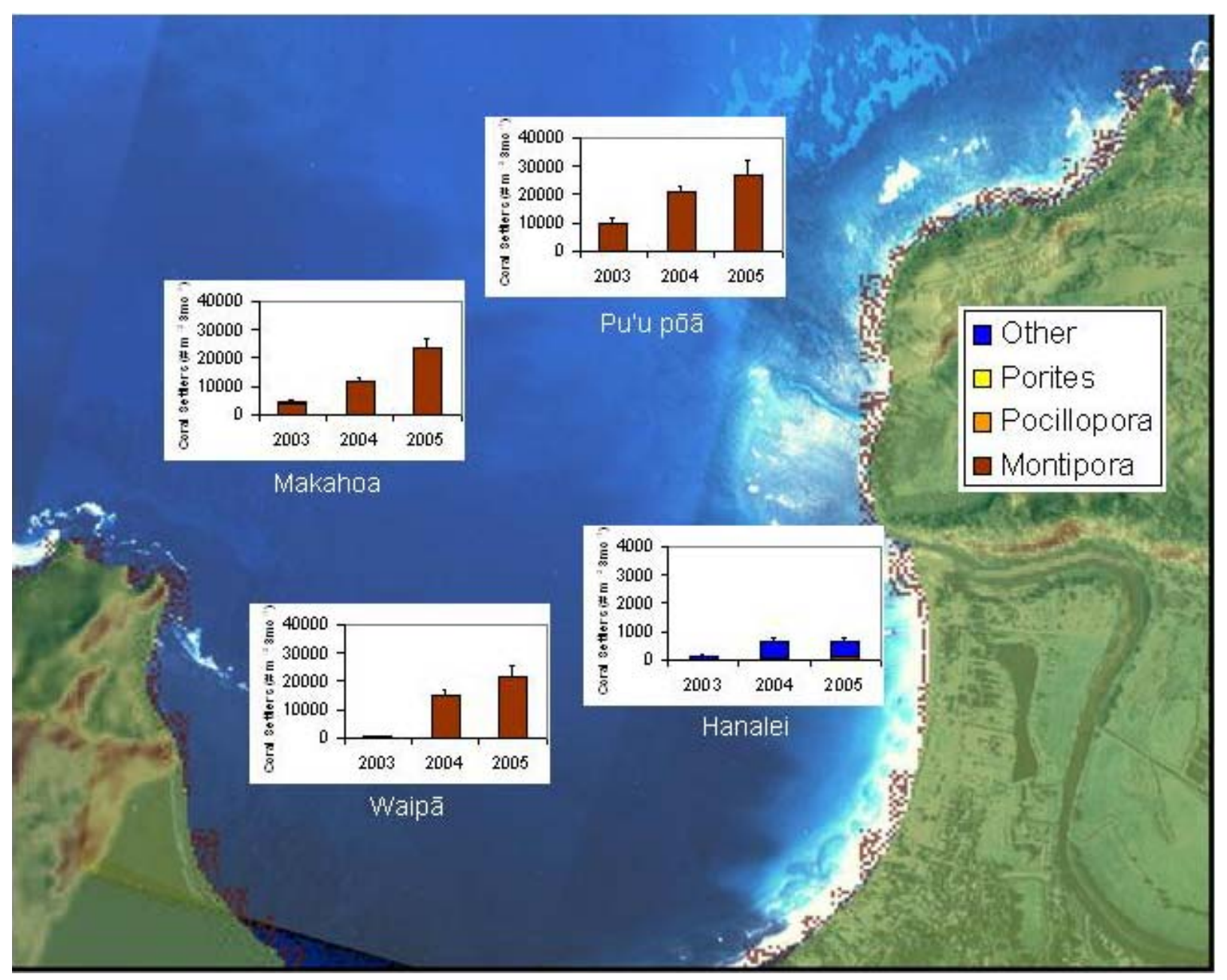

Figure 1. Average coral settlement rates (No. $\mathrm{m}^{-2} 3$ months ${ }^{-1}$ ) at each of the sites from 2003 to 2005. Nearly $99 \%$ of the settlement was composed of Montipora spp. Note the different Y-axis for the Hanalei site chart. Error bars are $\pm 1 \mathrm{SE}$. 


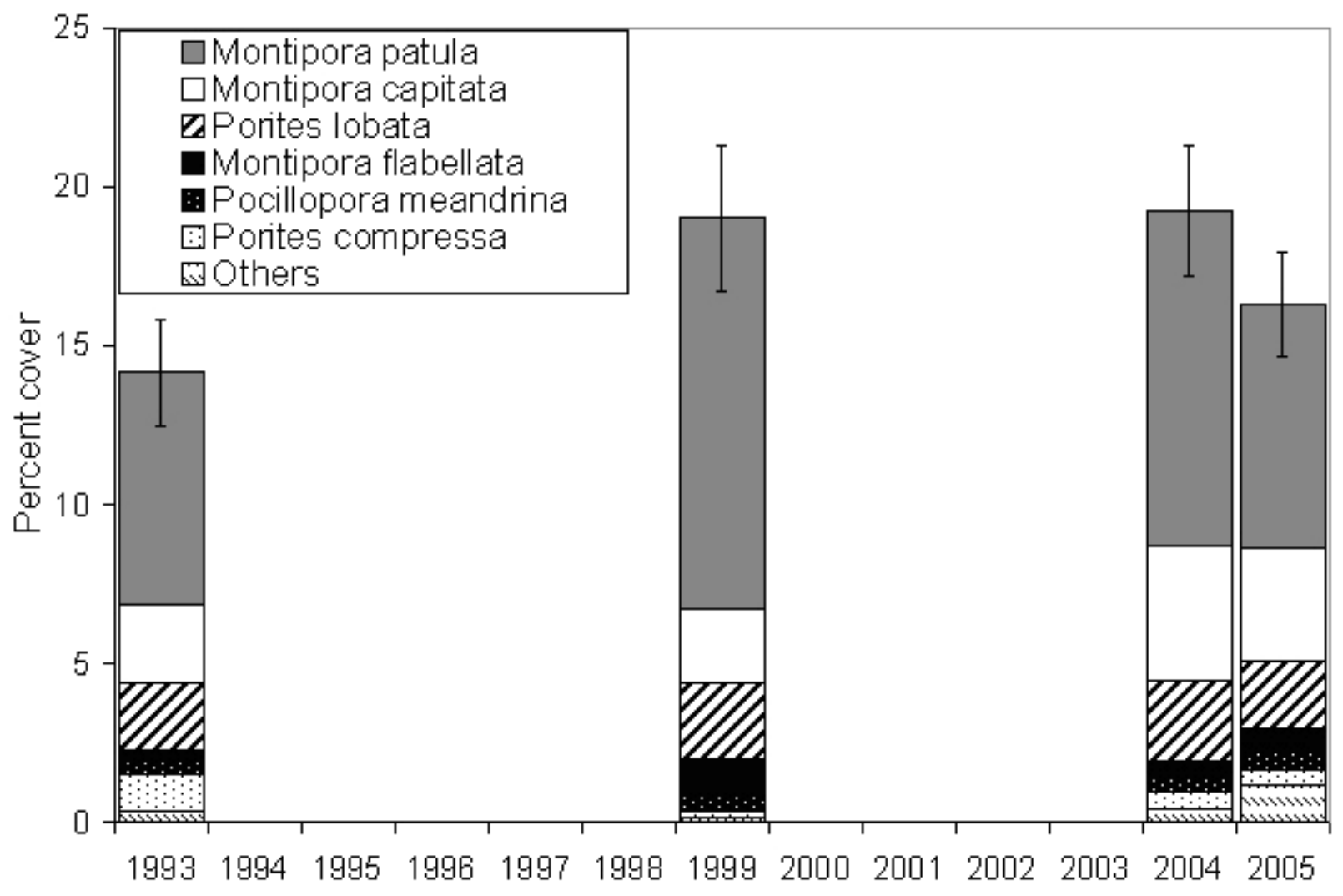

Figure 2. Change in percent coral cover by species in Hanalei Bay, during the different sampling periods. Error bars are $\pm 1 \mathrm{SE}$. 


\title{
Sediment Porewater Toxicity Study in Hanalei Bay, Kaua`i
}

\author{
Scott Carr' and Marion Nipper ${ }^{2}$
}

Toxicity tests are commonly conducted as a measure of the bioavailability of toxic chemicals to biota in an environment. Chemical analyses alone are insufficient to determine whether contaminants pose a threat to biota (Carr and Nipper, 2003). Porewater toxicity tests can provide ecologically relevant data on sensitive life stages of a variety of species to a broad range of contaminants (Carr and Nipper, 2003). The inclusion of porewater toxicity testing as an additional indicator of sediment quality provides a more comprehensive picture of contaminant effects in sensitive habitats. In this study purple-spined sea-urchin (Arbacia punctulata) fertilization and embryological development porewater-toxicity tests were used to evaluate the sediments from the coastal environment around Hanalei Bay, Kaua i, Hawaìi. These tests have been used previously to assess the bioavailability of contaminants associated with sediments in the vicinity of coral reefs (Carr and Nipper, 1998; Carr and others, 2001; Nipper and Carr, 2000, 2001).

As part of the Hanalei Bay Watershed study, sediment porewater samples were collected in situ at 11 sites in the Bay and at a reference site at Ke'e Beach (station 6) during the last week of August, 2005. Six of the samples were collected near shore in a water depth of approximately $2 \mathrm{~m}$, whereas the other six samples were collected at depths ranging from 5 to $15 \mathrm{~m}$. The porewater samples were collected using a diver-deployed syringe connected to a filtering medium, with $\sim 500 \mathrm{ml}$ of pore water collected per site. The porewater samples were kept at $4^{\circ} \mathrm{C}$ until they were transported back to the USGS Marine Ecotoxicology Research Station in Corpus Christi, Texas, where they were centrifuged for removal of particles and used in toxicity tests. The porewater samples were tested in a dilution series design using 20 $\mathrm{ml}$ glass scintillation vials as exposure chambers. Both the sea-urchin fertilization and embryological development tests were performed as these tests often show different responses to various contaminants with different mechanisms of toxicity. The results from the Hanalei Bay pore water were compared with pore water from the reference site in Kaua i (station 6, fig. 1) and from a reference site in Aransas Bay, Texas. Significant toxicity was observed at three stations $(8,10$ and 12) with the fertilization endpoint but no samples were toxic in the embryological development test (fig. 1). The concentration of ammonia and sulfide in the porewater samples was below the concentrations known to cause an effect in these tests. Toxicity identification evaluation (TIE) studies (Burgess and others, 1996) are recommended to determine what substances or classes of compounds are responsible for the observed toxicity. With the information obtained from a TIE study it may be possible to identify the

\footnotetext{
${ }^{1}$ USGS Marine Ecotoxicology Research Station, 6300 Ocean Dr., Ste. 3200, Corpus Christi, TX 78412

${ }^{2}$ Texas A\&M University, Center for Coastal Studies, 6300 Ocean Dr., Ste. 3200, Corpus

Christi, TX
} 
source of the primary contaminants of concern and reduce the inputs of these toxicants into this ecosystem.

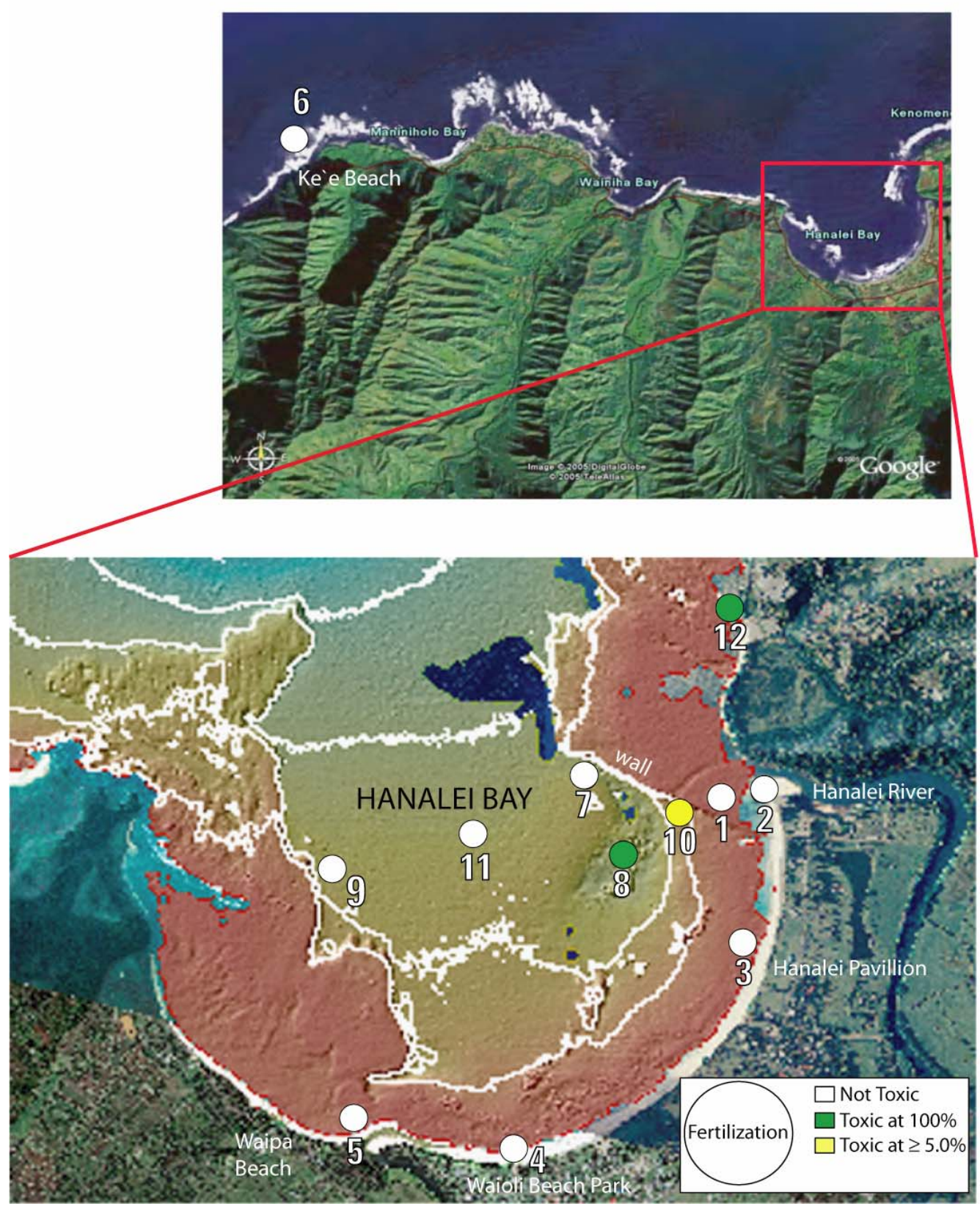

Figure 1. Toxicity test results for samples taken in Hanalei Bay, Kaua `i, Hawai i. Color differentiation of the circles indicates level of toxicity observed in the sea-urchin fertilization test. There were no toxic samples observed for the sea urchin embryological development test. 


\section{Literature Cited}

Burgess, R.M., Ho, K.T., Morrison, G.E., Chapman, G., and Denton, D.L., 1996, Marine toxicity identification evaluation (TIE): U.S. Environmental Protection Agency, Washington, DC, Phase I guidance document, EPA/600/R-96/054, 70 p.

Carr, R.S., and Nipper, M., 1998, Preliminary survey of sediment toxicity in the vicinity of Honolulu, Hawai'i: Internal report to U.S. Geological Survey, Menlo Park, CA, 18 p.

Carr, R.S., and Nipper, M. (eds.), 2003, Porewater toxicity testing; Biological, chemical, and ecological considerations: Society of Environmental Toxicology and Chemistry (SETAC), Pensacola, FL, 346 p.

Carr, R.S., Nipper, M., and Plumlee, G.S., 2001, A preliminary survey of marine contamination from mining-related activities on Marinduque Island, Philippines; Porewater toxicity and chemistry; Results from a field trip October 14-19, 2000: U.S. Geological Survey Open-File Report 01-441, 19 p. [http://geology.cr.usgs.gov/pub/open-filereports/ofr-01-0441]

Nipper, M. and Carr, R.S., 2000, Toxicity testing of sediment pore water from the Flower Garden Banks, Gulf of Mexico: Final report prepared for the Center for Coastal Studies, Texas A\&M University-Corpus Christi, Corpus Christi, TX, 7 p.

Nipper, M., and Carr, R.S., 2001, Porewater toxicity testing; a novel approach for assessing contaminant impacts in the vicinity of coral reefs: Bulletin of Marine Science, v. 69, p. 407420. 


\title{
Investigating the Use of Remote Sensing for Watershed Landscape
}

\section{Analyses with Applications to Water Erosion Vulnerability and}

\section{Sedimentation in Hawai ì: Hanalei, Kaua i}

\author{
Pat Chavez', Jo-Ann Isbrecht', Rian Bogle', and Miguel Velasco'
}

A main objective of this project is to investigate the use of remotely sensed satellite and airborne image data, along with field-based instrumentation, to detect, map, and monitor parameters that are important to help determine the vulnerability of the landscape to water erosion and it's potential impact on critical habitats, with special emphasis on coral reefs. The main study sites for the project are on south Moloka' $i$ and the Hanalei watershed on north Kauài.

The work at Hanalei includes:

- The use of Quickbird satellite images, which have $0.6 \mathrm{~m}$ and $2.4 \mathrm{~m}$ pixels, to investigate vegetation mapping (see Jacobi and Ambagis, this vol., p. 42), vegetation cover and sheltering of the soils, and vegetation change detection.

- Experiment with the use of our airborne digital-camera system, turned sideways, to image very steep cliffs to see if this type of imaging can be used to help identify and map the vegetation on such difficult to access terrain (with Jim Jacobi).

- Use of multi-temporal Quickbird satellite images to detect and map existing and new landslides within the Hanalei watershed, and to determine their role sediment source within the watershed.

- Investigating the use of a field instrument developed for the remote sensing community (spectral radiometer) to see if it can be used to monitor the amount of sediment being transported by the Hanalei River into the bay. If successful, such a relatively low-cost instrument could be used to monitor different parts of a watershed and help determine, to a first order or relative amounts, the sediment contribution from different parts of a watershed (with Barry Hill and Carl Berg).

- Investigate the use of Quickbird satellite and airborne imaging to detect and monitor the amount and spatial distribution of suspended sediment concentration levels within the taro fields and the nearby Hanalei River. We want to determine if these types of data could be used to detect and monitor suspended sediment loads in the taro fields

\footnotetext{
${ }^{1}$ USGS Southwest Geography Science Team, 2555 N. Gemini Dr., Flagstaff, AZ 86001
} 
and the contribution to the total amount of sediment going into the bay (with Carl Berg).

Note: these same data may be useful to help map and monitor critical bird habitats within the lower part of the watershed, including in and around the taro fields.

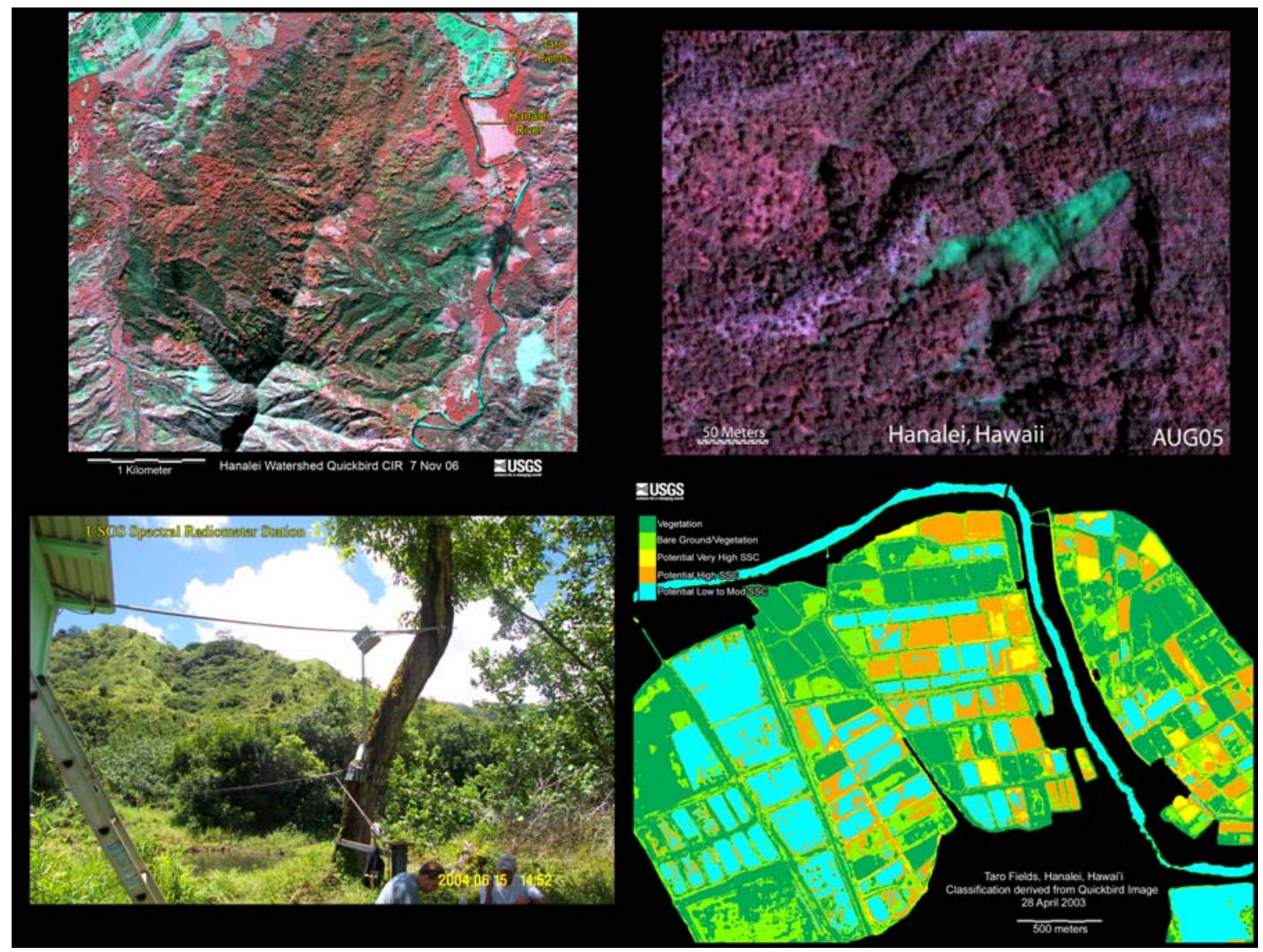

Upper Left: Portion of a Quickbird satellite image showing an area at the lower end of the watershed with potentially stressed vegetation.

Upper Right: Portion of a Quickbird satellite image showing a relatively new landslide on the upper portion of the watershed (green).

Lower Left: A photo showing the spectral radiometer mounted close to the traditional USGS water gage station on the lower end of the Hanalei River.

Lower Right: Portion of a Quickbird satellite image covering the FWS taro fields. The image data have been classified to display the potential levels of suspended sediment concentration (SSC). 


\title{
Distribution of mud in Hanalei Bay, Kaua ì: June vs. September 2006
}

\author{
Susan Cochran', Mike Field', and Curt Storlazzi ${ }^{1}$
}

An experiment was conducted to determine the amount of mud versus sand in various locations of Hanalei Bay during the summer of 2006 with two questions in mind: (1) is there a gradient or any apparent pattern to the distribution? and, (2) what is the overall gain or loss over the course of the summer?

Sediment was hand-sampled in June and September 2006 by divers using $20 \mathrm{~cm}$-long push-cores. The sediment from each short core was wet-sieved and dried, and weight of sand versus weight of mud was determined. In general, the sand-sized fraction of the samples was predominantly carbonate sand, while the mud component was typically dark, terrigenous material.

Figures 1 and 2 show the percentage of mud versus sand for samples collected in June and September 2006, respectively. The highest amounts of mud (up to 94\% in June) were found in samples collected near the "Wall" where the mouth of the Hanalei River cuts across the reef flat and enters the bay. Not surprisingly, high amounts of mud (up to $89 \%$ in June) were also found in samples collected from what is known as the "Black Hole." Samples collected from the middle of the bay and from the western side of the bay were relatively mud-free and consisted of nearly $100 \%$ clean, carbonate sand.

Figure 3 shows the difference of mud percent from June to September 2006. Samples from the Black Hole had the highest increase of mud over the summer period, possibly due to terrestrial input from Hanalei River during summer floods. However, samples collected from the middle of the bay show a decrease in mud from June to September. The loss of fine sediment from the middle of the bay may have resulted from wave-driven remobilization (see Storlazzi and others, this vol., p. 76).

Overall, the patterns of mud distribution confirm the isotope measurements made by Draut and others (this vol., p. 22). Mud entering the marine system from discharge by the Hanalei River is primarily deposited along the eastern rim of the bay near the river mouth. Residence time of mud in this locale can be long (months to years), as it is apparently only slowly reworked and transported out of the bay. In contrast, we infer that the center and western portions of the bay are areas of minimal deposition (bypassing) or short residence time due to higher reworking rates caused by higher wave stresses.

\footnotetext{
${ }^{1}$ USGS Pacific Science Center, 400 Natural Bridges Dr., Santa Cruz, CA 95062
} 


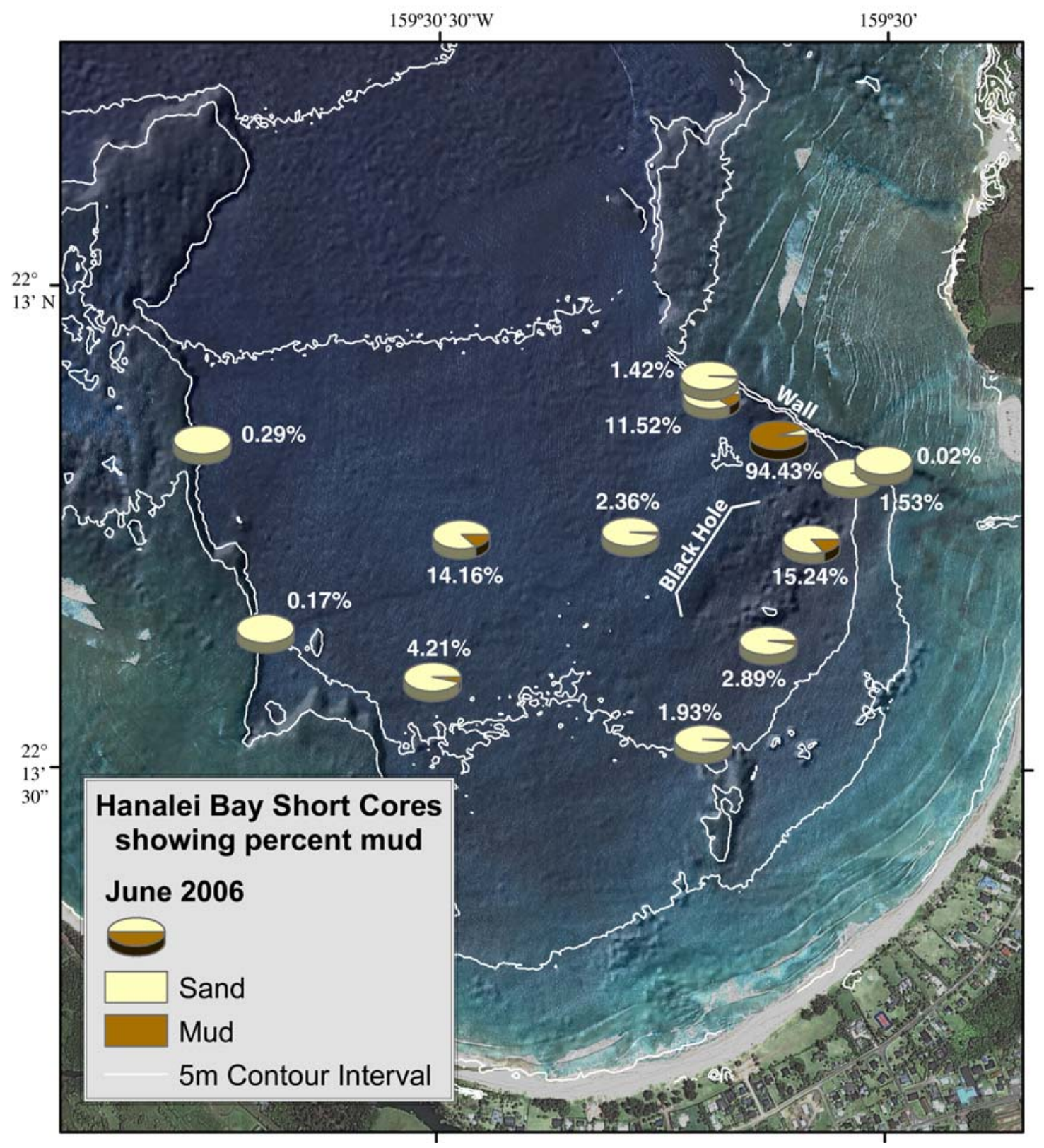

Figure 1. Image of Hanalei Bay showing sample locations and percent mud of samples collected in June 2006. 


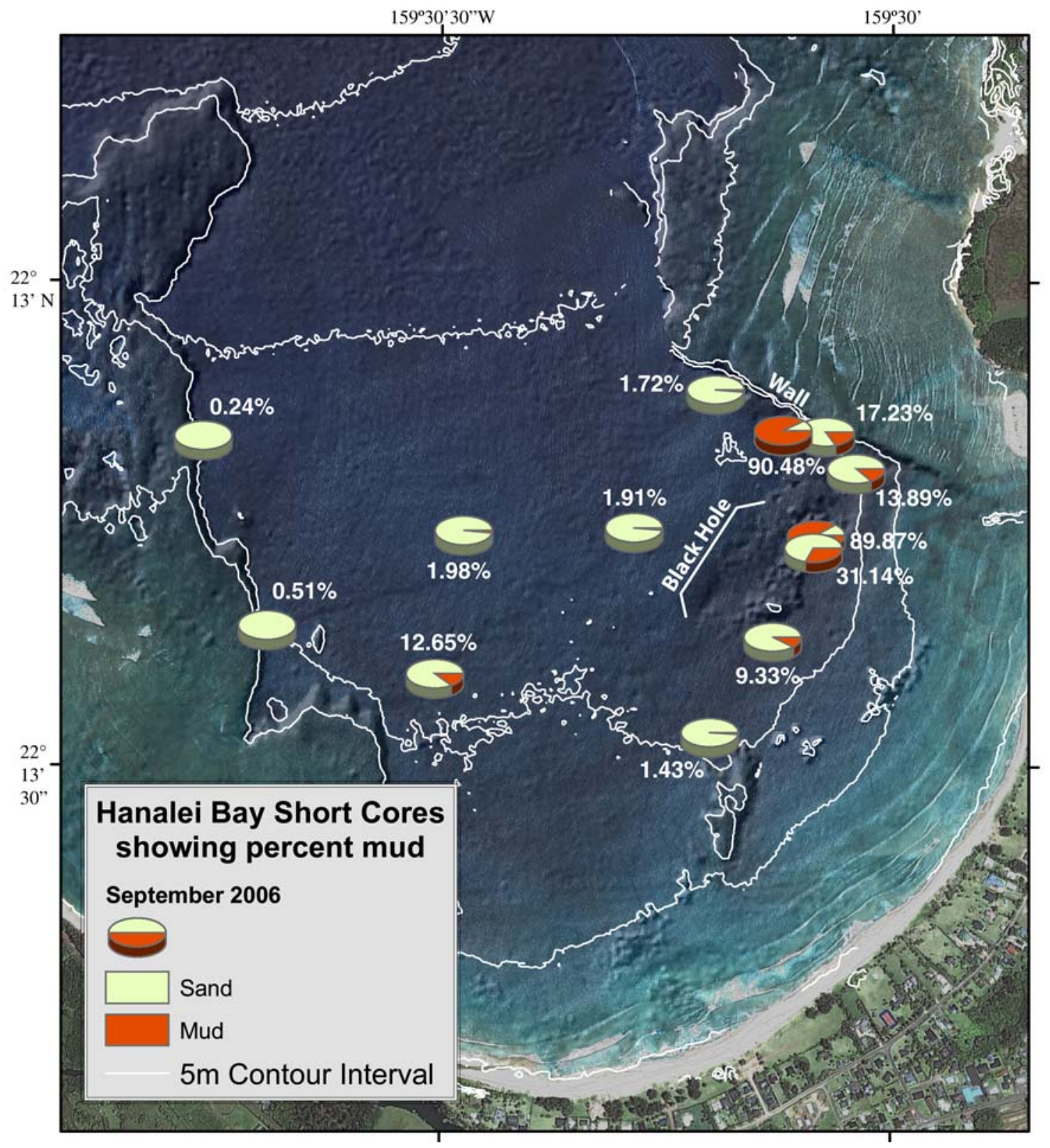

Figure 2. Image of Hanalei Bay showing sample locations and percent mud of samples collected in September 2006. 


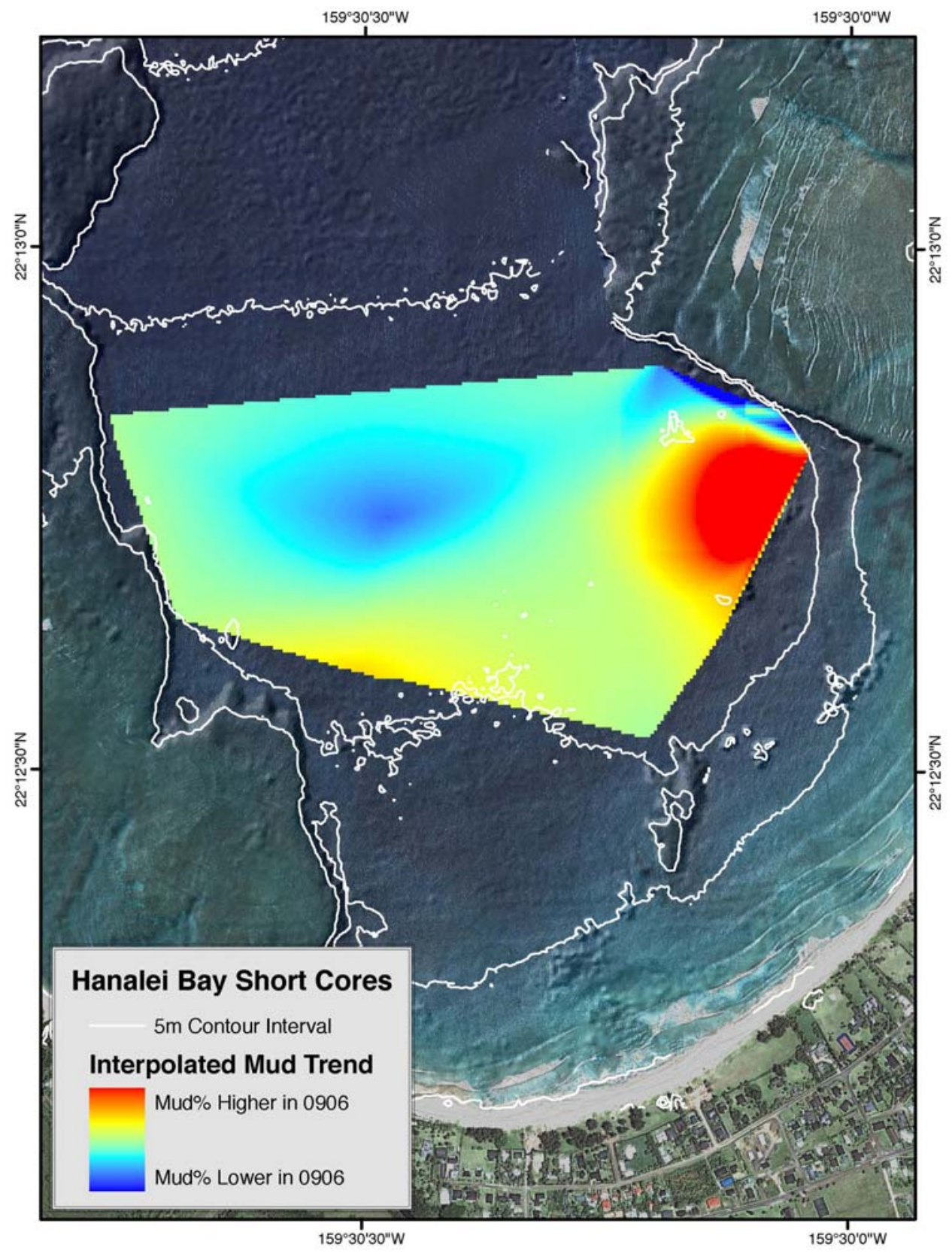

Figure 3. Image of Hanalei Bay showing the difference of mud percent from June to September 2006. The boundaries of the mapped results are limited by the actual data points used for the interpolation. 


\section{Seasonal Flood Deposits in Hanalei Bay, Kaua i, HI}

Amy Draut', Mike Field', Mike Bothner', Susan Cochran', Michael Casso', Sandy Baldwin', Richard Reynolds', Josh Logan', and Curt Storlazzi'

Sedimentary facies, short-lived isotopes ${ }^{7} \mathrm{Be}$ and ${ }^{137} \mathrm{Cs}^{4}$, and magnetic properties of sediment cores in Hanalei Bay, Kaua i, HI, were used to assess spatial and temporal patterns of sediment deposition associated with seasonal flooding of the Hanalei River over two years. Sediment cores were collected from the seafloor within Hanalei Bay in early and late summer 2005 and 2006 (fig. 1).

The Hanalei River delivers terrigenous sediment and organic matter to reef-lined Hanalei Bay. The youngest and thickest terrigenous sediment (recognizable by its short-lived isotope activity, sedimentary facies, and magnetic properties) was observed on the east side of the bay: near the Hanalei River mouth and in a bathymetric depression known locally as the Black Hole that acts as a temporary sediment sink. During this two-year study, the largest flood events occurred between February and April 2006, when the Hawaiian Islands experienced sustained heavy rainfall, and abundant terrestrial runoff entered Hanalei Bay (fig. 2); we focus here primarily on data collected in the second year of the study. Data from the first year of the study were published by Draut and others (2005).

The winter 2006 floods provided the largest amount of terrestrial deposits in the bay during this study, leaving flood deposits in the eastern bay that, by June 2006, were on the order of $10 \mathrm{~cm}$ thick (fig. 3; deposits were thickest in the Black Hole). Abundant wood and organic debris were also deposited on the sea floor in the eastern bay near the river mouth, in the Black Hole and along the eastern reef wall. The winter 2006 flood deposits have high ${ }^{7} \mathrm{Be}$ activity, finer grain size, a lower proportion of carbonate, and contain abundant terrestrial plant matter compared with marine sediment in the cores. Cores collected farther from the river mouth were dominated by carbonate sand with little or no ${ }^{7} \mathrm{Be}$ as of June 2006 ; carbonate facies were typical at Stations B, D, E, and H (fig. 1) each time they were cored. Preliminary mass-balance calculations indicate that between 13 and 20 percent of the terrestrial sediment delivered to the

\footnotetext{
${ }^{1}$ USGS Pacific Science Center, 400 Natural Bridges Dr., Santa Cruz, CA 95060

${ }^{2}$ USGS Woods Hole Science Center, 384 Woods Hole Rd., Woods Hole, MA 02543

${ }^{3}$ USGS, PO Box 25046, Denver Federal Center, MS 980, Denver, CO 80225

${ }^{4}$ Activity levels of ${ }^{7} \mathrm{Be}$ and ${ }^{137} \mathrm{Cs}$ are commonly analyzed in shallow marine cores to identify terrestrial sediment recently delivered to the ocean. ${ }^{7} \mathrm{Be}$ is a naturally occurring isotope with 53day half-life, formed in the atmosphere by cosmic-ray spallation of nitrogen and oxygen. It becomes associated with vegetation and soil and is concentrated in terrestrial sediment carried to the ocean by river discharge. ${ }^{7} \mathrm{Be}$ remains detectable for up to five half-lives $(\sim 8$ months $) .{ }^{137} \mathrm{Cs}$ is an anthropogenic (bomb-derived) isotope with non-constant source function and 30-year halflife. Measurable ${ }^{137} \mathrm{Cs}$ indicates that sediment has been in contact with an atmospheric or fluvial source more recently than the 1950s, when this isotope first entered the environment.
} 
bay by the Hanalei River between September 2005 and June 2006 remained in the bay as of early June 2006.

A Hanalei River flood occurred on August 7, 2006, that was smaller than floods the previous winter but still a substantial discharge event for the summer season (fig. 2). Terrestrial sediment delivered by that flood was apparent in the Black Hole as of September 2006 but little sedimentary and isotopic evidence of the summer flood was present elsewhere in the bay by September. Stations A and I (both located in the Black Hole; fig. 1) were the only two sites at which ${ }^{7}$ Be inventory in September 2006 was higher than could be accounted for simply by decay of the ${ }^{7} \mathrm{Be}$ inventory that was present at those locations in June 2006. Stations A and I showed factors of 3 and 1.2, respectively, elevation in ${ }^{7}$ Be inventory in September above the expected value from decay of the June inventory. This indicates the presence of new terrestrial sediment at those two sites, most of which presumably resulted from the flood on August 7. This interpretation is supported by magnetic studies that suggest somewhat different sediment sources for the winter and summer flood events.

Deposits from the winter 2006 floods continued to dominate the sedimentary record in the eastern bay through early fall, even after the addition of newer sediment in the August 7 flood. This high level of sedimentation is consistent with the much higher sediment input of the winter floods compared with the August 7 flood (fig. 2). Peak daily water discharge in the largest winter flood (February 21, 2006) was a factor of 2.6 greater than that of the August 7 flood, whereas sediment concentration on that winter flood day exceeded the sediment concentration on August 7 by a factor of 5.9. Although it is common for sediment concentration to increase exponentially with water discharge in the rating curves of most streams, the very elevated sediment concentrations in the winter floods may have occurred in part because the Hanalei drainage basin responded differently to the prolonged winter rain than to the more episodic summer rain, perhaps producing additional sediment in the winter by landslides and other masswasting processes.

Sediment accumulating in the open center of the bay and on its fringing reefs is most readily remobilized and advected out of the bay during winter, when oceanographic conditions are energetic. In summer, wave and current measurements made concurrently with this study (Storlazzi and others, 2006) showed weak currents $(\sim 1 \mathrm{~cm} / \mathrm{s}$ near the bed) and little wave energy, indicating that sediment delivered during summer floods most likely remains in the bay until winter storms can remove it. Increased turbidity and sedimentation on corals resulting from floods of the Hanalei River (as was documented by a camera station in the eastern bay in summer 2006) could affect the sustainability of coral reefs and their many associated species. This is a particular concern during summer months when wave energy is low and sediment is not readily remobilized and advected out of the bay. As shown by our mass-balance estimates for June 2006 above, however, even winter flood sediment can persist in the bay for months if the wave climate is not energetic enough to transport sediment into the open ocean. 


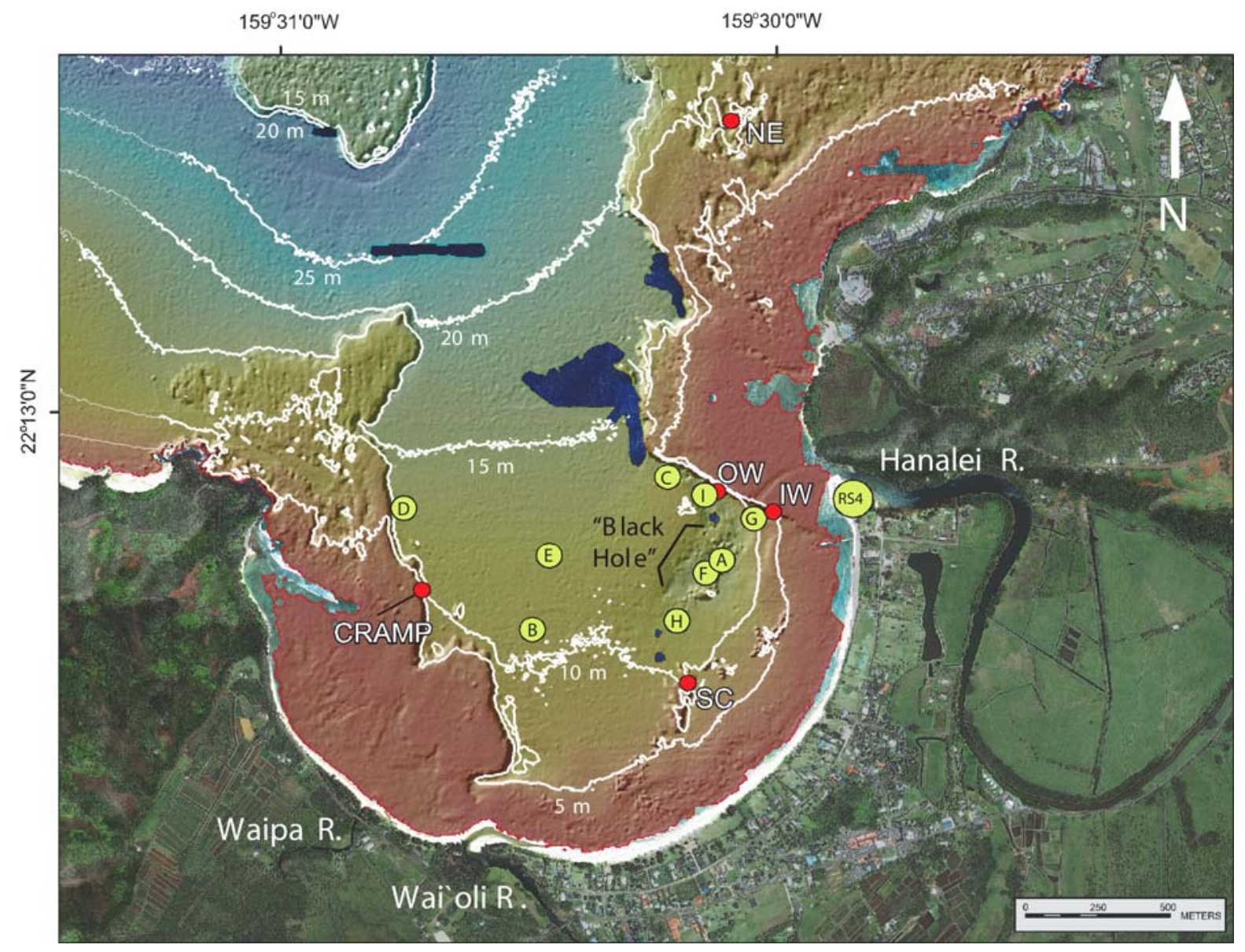

Figure 1. Locations of sediment-core sites in Hanalei Bay: yellow circles identified by station letter (A-I). Red circles indicate the locations of oceanographic instrument packages deployed during summer 2005 and 2006 (see Storlazzi and others, 2006 for complete description of abbreviations and instrumentation; the CRAMP site is one used by University of Hawai'i's Coral Reef Assessment and Monitoring Program). Bathymetry in this image has been interpolated from SHOALS lidar data; dark-blue areas indicate no bathymetric data. The isobath interval is $5 \mathrm{~m}$. 


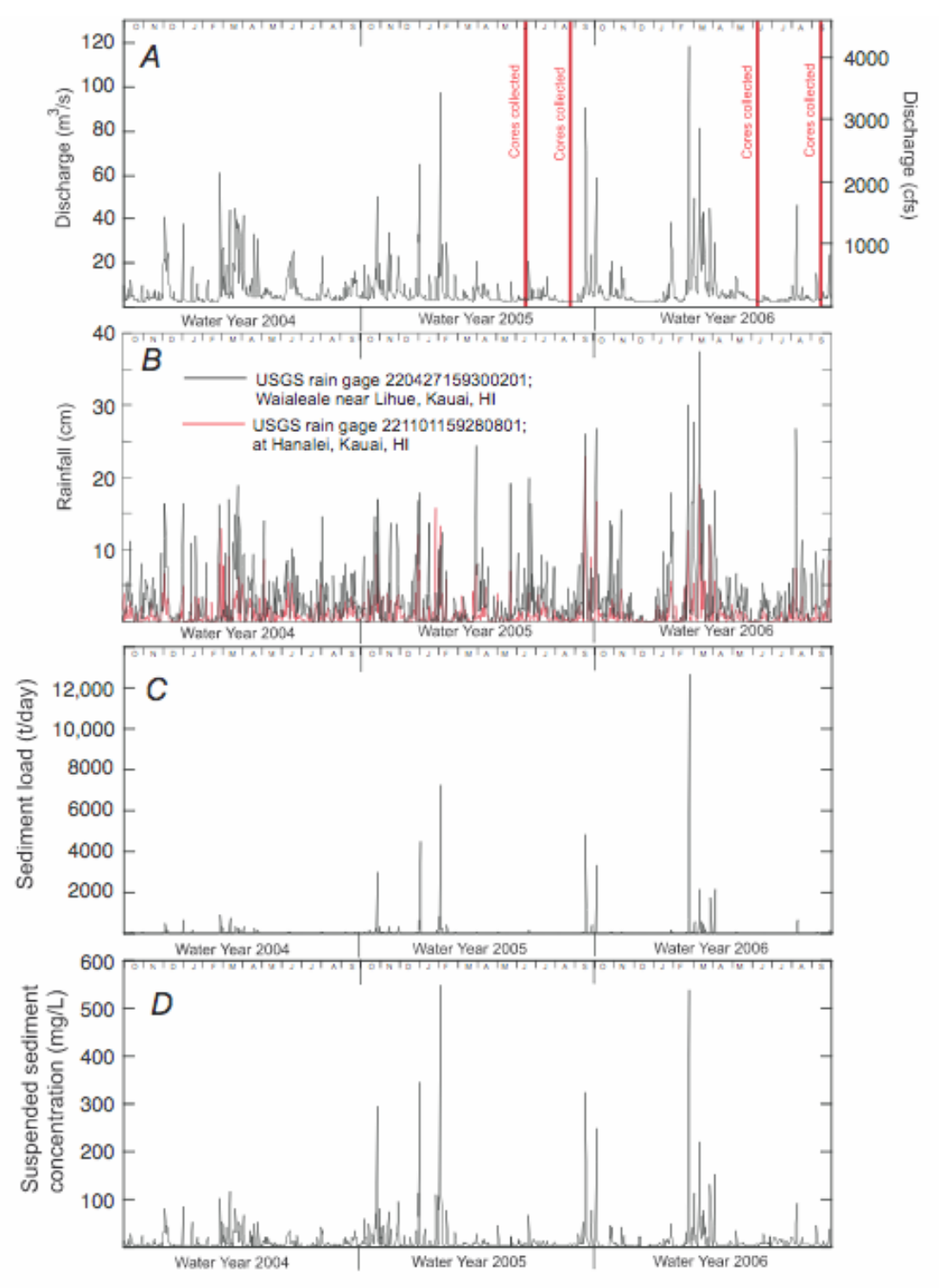

Figure 2. A. Water discharge from the Hanalei River. Data were measured at USGS gaging station number 16103000 ("Hanalei River near Hanalei", located $9.2 \mathrm{~km}$ upstream from the river mouth) and were provided by the USGS Pacific Islands Water Science Center in Honolulu, Hawai i [http://hi.water.usgs.gov/]. This hydrograph spans water years 2004-2006 (September 1, 2003 through September 30, 2006) with times of core collection indicated. B. Precipitation $(\mathrm{cm})$ in the Hanalei River drainage basin recorded at two USGS rain gages. C. Fluvial sediment load (in metric tons per day) based on a rating curve and suspended-sediment samples analyzed by the Water Resources Division of the USGS. D. Suspended-sediment concentration in the Hanalei River measured at USGS gaging station 16103000. 


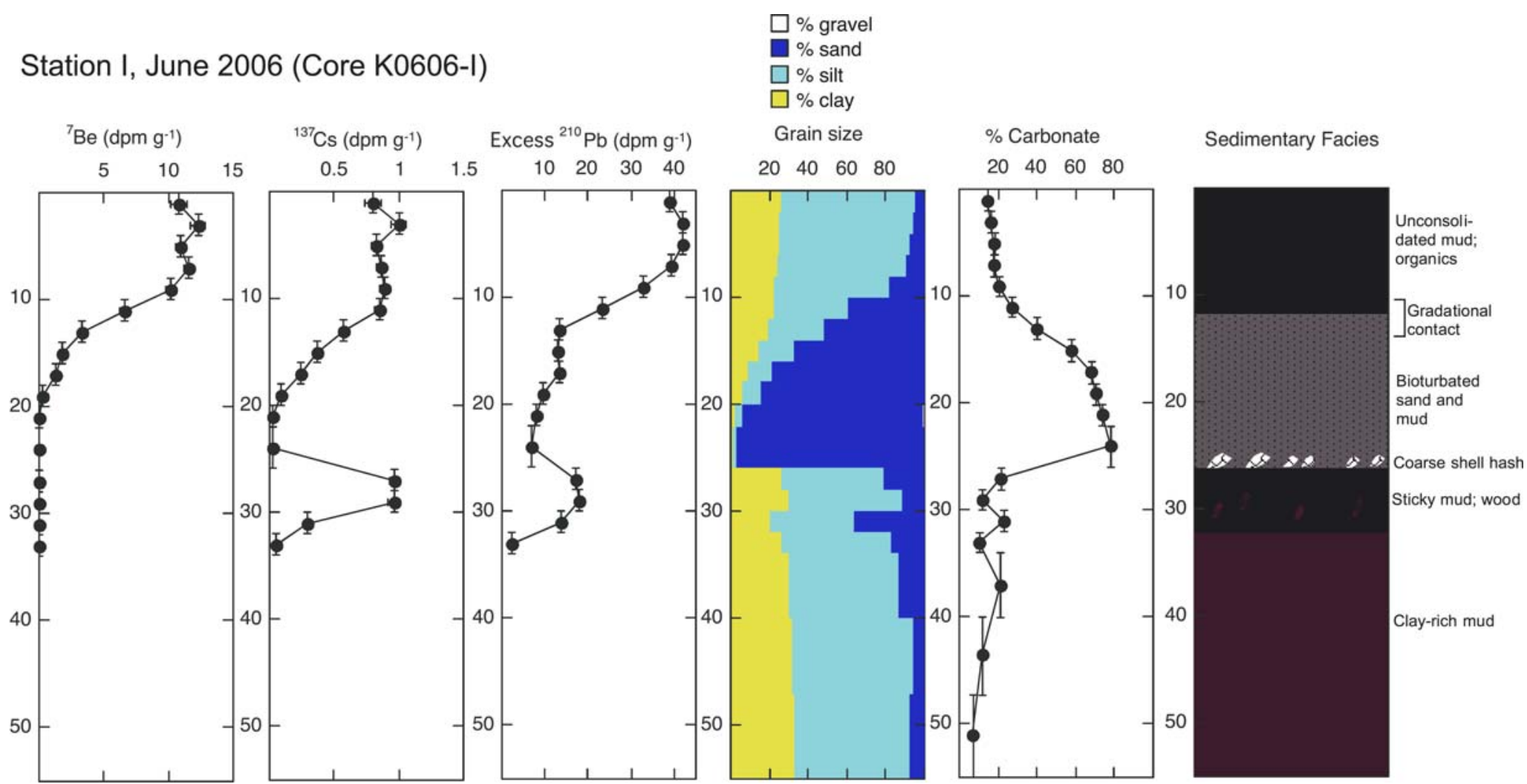

Figure 3. Sedimentary facies, grain size, percent carbonate, and isotope activity at Station I in June 2006. Activities of ${ }^{7} \mathrm{Be},{ }^{137} \mathrm{Cs}$, and excess ${ }^{210} \mathrm{~Pb}$, all decay-corrected to the date of sample collection, are shown in disintegrations per minute (dpm) per dry gram of saltfree sediment. This site is located at the north end of the Black Hole, in eastern Hanalei Bay. Much of this core contains terrigenous sediment, which is identifiable from its low percent carbonate (high mud) content and abundant terrestrial organic matter. Sediment between $\sim 12$ and $27 \mathrm{~cm}$ is more dominantly marine than the rest of the core, with a higher proportion of carbonate material. The upper $\sim 12 \mathrm{~cm}$ of this core comprise a recent flood deposit, containing high levels of ${ }^{7} \mathrm{Be}$ and unconsolidated mud and organic matter. This sediment, inferred to have been deposited by the large floods between February and April 2006, was detectable down to a depth of $\sim 18$ $\mathrm{cm}$ (based on the ${ }^{7} \mathrm{Be}$ profile), having mixed with more carbonate-rich marine sediment. 


\section{References}

Draut, A. E., Field, M. E., Bothner, M. H., Logan, J. B., Casso, M. A., Baldwin, S. M., and Storlazzi, C. D., 2006, Coastal Circulation and Sediment Dynamics in Hanalei Bay, Kaua`i, Hawai i, Part II, Tracking Recent Fluvial Sedimentation: Isotope Stratigraphy Obtained in Summer 2005. U.S. Geological Survey Open-File Report 2006-1125, 52 p. [http://pubs.usgs.gov/of/2006/1125]

Storlazzi, C.D., Presto, M.K., Logan, J.B., and Field, M.E., 2006, Coastal circulation and sediment dynamics in Hanalei Bay, Kaua i. Part I: Measurements of waves, currents, temperature, salinity and turbidity: June-August, 2005, U.S. Geological Survey Open-File Report 2006-1085, 35 p. [http://pubs.usgs.gov/of/2006/1085] 


\title{
Riparian Composition and Function in a Small Watershed in Hanalei,
}

\section{Hawaì i}

\author{
Carl Evensen' and Guy Ragosta'
}

Riparian areas have not been adequately studied in Hawai $i$ or other island ecosystems. Study of composition and function of riparian vegetation is needed to assess the influence of riparian areas on water quality, hydrology, and pollutant transport, and to guide sustainable watershed management. Riparian vegetation and associated soil and water-quality parameters have been characterized for Waipa Stream, a small watershed in Hanalei, on the northern coast of Kaua i. Data collected from 2004 to 2005 include plant species composition, stem diameter, canopy and groundcover, as well as stream turbidity, dissolved oxygen and Enterococcus bacteria concentrations. Riparian vegetation and soils were characterized in twenty-four plots along stratified sections of Waipa Stream, along with two major tributaries that flow into upper-and mid-Waipa Stream, and a lower floodplain cattle-pasture diversion ditch. We characterized vegetation by measuring stem diameter, using a densitometer for canopy cover, and a modified pin-drop method for ground cover. Site conditions were assessed with chemical analysis of surface soils and background soil Enterococcus and E. coli levels. Weather stations were installed at upper and lower portions of the watershed. In-stream temperature gauges were deployed at the beginning and end of each vegetation community along the stream, and at the confluences of the tributaries above the stream entrance. At these locations we tested water quality for Enterococcus levels, streamflow, turbidity, EC, DO, and salinity at specified dates.

The Waipa watershed riparian areas are dominated by alien species, which were differentiated into four major vegetation communities, which differ significantly in species composition, canopy, and ground cover. Lower Waipa stream is significantly lower in canopy cover than Kolopua tributary. Basal area in the Kapalikea tributary is significantly lower than in mid- Waipa stream riparian communities, which are dominated by dense Mangifera indica and numerous Psidium cattleianum plants. Zingiber zerumbet ground cover is significantly higher in summer 2004 than winter 2005, while the reverse is true for Christella dentata. Over all areas studied, invasive species significantly dominate ground cover, basal area, and canopy cover. Enterococcus levels and turbidity decrease while dissolved oxygen increase in streams with increasing elevations in the watershed. Distribution and density of domestic cattle and feral pigs seem to be directly related to water quality impairment.

\footnotetext{
${ }^{1}$ University of Hawai i, College of Tropical Agriculture and Human Resources, Dept. of Natural Resources and Environmental Management, 1910 East-West Rd., Sherman 101, Honolulu, HI 96822
} 


\section{Acknowledgements}

This research has been accomplished with support from the USDA CSREES Water Quality program, along with strong partnerships with NRCS, Regional Land Grants (Universities of Nevada and California), and with faculty from the University of Hawai $i$ WRRC, Sea Grant Extension and the Botany Department as well as in-kind support and assistance from the EPA funded Hanalei Watershed Initiative and a community group, the Waipa Foundation. 


\title{
Evaluation of a Non-Point Source Pollution Model, AnnAGNPS, in
}

\section{Hanalei Watershed, Kaua i}

\author{
Ali Fares
}

Impaired water quality caused by human activity and the spread of invasive plant and animal species has been identified as a major factor of degradation of coastal ecosystems in the tropics. The main goal of this study was to evaluate the performance of AnnAGNPS (Annualized Agricultural Non-Point Source) watershed model, in simulating runoff and soil erosion in a $50 \mathrm{~km}^{2}$ watershed located on the island of Kaua i, Hawai i. The model was calibrated and validated using 2 years of observed stream-flow and sediment-load data. Alternative scenarios of spatial rainfall distribution and canopy interception were evaluated.

Initially, the model produced high $\mathrm{CN}$ values, which resulted in increased simulated runoff ( $\mathrm{CN}$ is a curve number used to estimate run-off based on soil and cover type). To overcome this problem the initial $\mathrm{CN}$ values were reduced to their lower-limit values for the corresponding land cover types. Simulations showed that in order to account for canopyinterception effect, a site-specific canopy interception model was preferable over the algorithm provided in AnnAGNPS. Accurate representation of the spatial distribution of precipitation is critical for accurate model performance. It was demonstrated that even with limited number of climate stations within the watershed, an adequate representation of spatial rainfall distribution could be achieved using an accurate annual precipitation map. Monthly runoff volumes predicted by AnnAGNPS compared well with the measured data $\left(\mathrm{R}^{2}=0.90\right)$, however up to $60 \%$ difference between the actual and simulated runoff were observed during the driest months (May and July). Prediction of daily runoff was less accurate $\left(\mathrm{R}^{2}=0.55\right)$.

During sensitivity analysis it was found that predicted sediment yield from the watershed was closely related to: vegetation root mass, average canopy fall height, soil erodibility, percentage of ground residue cover, and canopy cover ratio. The latter two parameters had the greatest influence on sediment yield. The entire watershed was covered by dense vegetation, which protects the soil from direct rainfall impact. Under these conditions high sediment yield was observed on areas with low clay content and on steep slopes. RUSLE erosion factor $\mathrm{K}$, which is directly related to soil properties, was the single most important parameter which influenced spatial variability of sediment losses. Predicted and observed sediment yield on a daily basis were moderately correlated $\left(\mathrm{R}^{2}=0.5\right)$. For the events of small magnitude, the model generally overestimated sediment yield, while the opposite was true for larger events. Total monthly sediment yield varied within $50 \%$ of the observed values, except for May 2004. It was found that approximately one third of the watershed area had low

\footnotetext{
${ }^{1}$ University of Hawai i, College of Tropical Agriculture and Human Resources, Dept. of Natural Resources and Environmental Management, 1910 East-West Rd., Sherman 101, Honolulu, HI 96822
} 
sediment yield (0-1 $\left.\mathrm{t} \mathrm{ha}^{-1} \mathrm{y}^{-1}\right)$, and presented limited erosion threat. However, five percent of the area had sediment yields in excess of $5 \mathrm{t} \mathrm{ha}^{-1} \mathrm{y}^{-1}$ (tons per hectare per year). Fifty one percent of the total area of the watershed contributed with less than $10 \%$ of total sediment generated; however, $49 \%$ of watershed generated over $90 \%$ of the total sediment (fig. 1). The results are based on the use of original NRCS soil classification and USGS land cover map with baseline curve numbers.

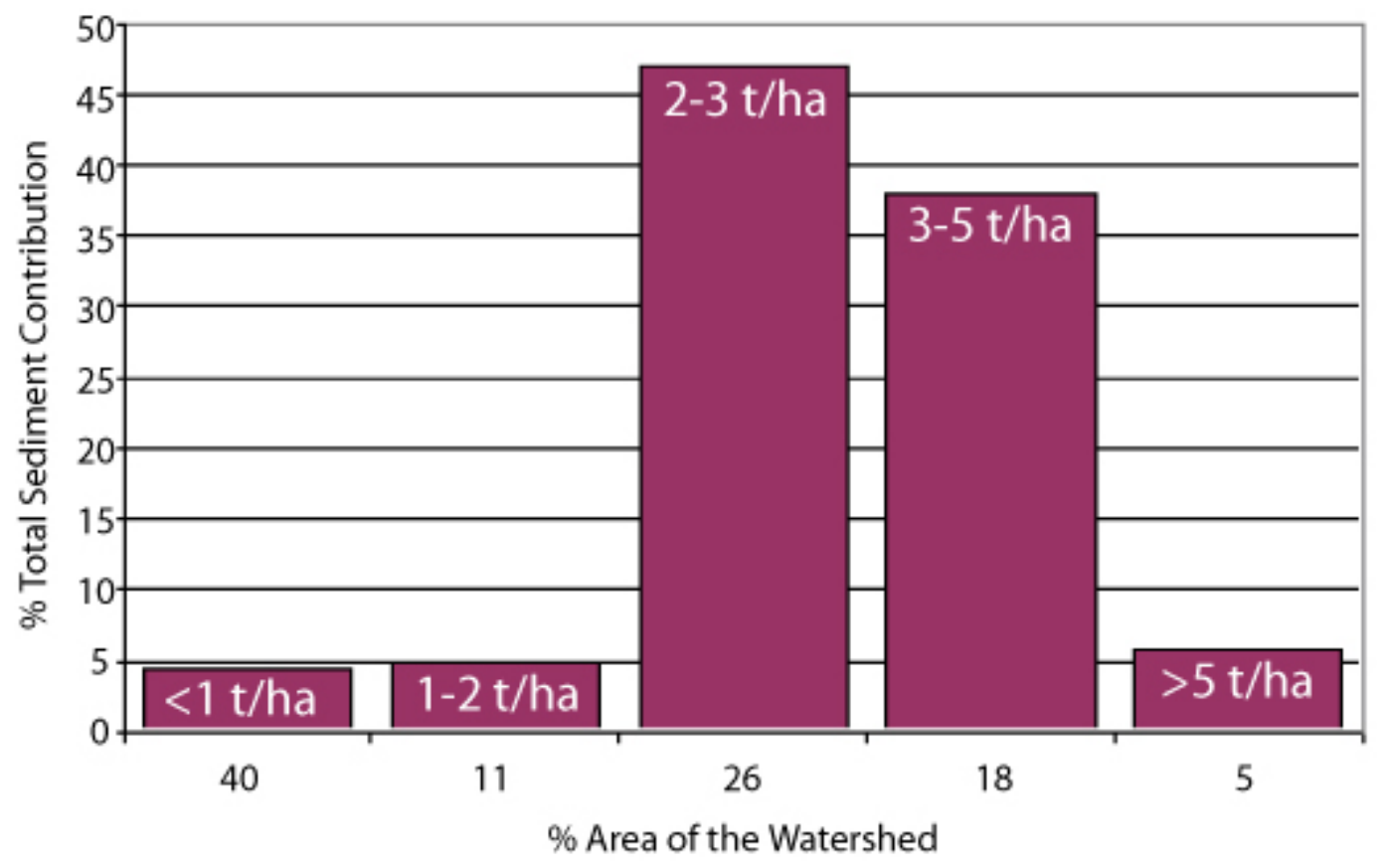

Figure 1. Total sedimentation contribution versus percent area of watershed contributing to the sediment load.

The model was re-calibrated due to the availability of an updated NRCS soil classification and a higher resolution and species-specific land-cover map developed by USGS (see Jacobi and Ambagis, this vol., p. 42). Predicted runoff and sediment load using the new parameters were more accurate compared to those estimated with the original soil classification and Landsat land-cover map. For 2003, predicted runoff and sediment were over $99 \%$ of the measured values. The re-calibrated input parameters were used to predict runoff and sediment for 2004 as well. The USGS land cover map with the updated soil classification produced slightly overestimated runoff and sediment load.

In Hanalei, feral pigs are one of the major causes of pollution. The soil disturbance due to their activities in the watershed results in increased sedimentation in the coastal areas. The implementation of feral pig damage estimates resulted in substantial increase of sedimentation due to the high sensitivity of the model to the surface residue cover parameter.

Figure 2 illustrates the predicted pig-damaged areas in the Hanalei watershed. An area with $40 \%$ surface cover disturbed is labeled high pig disturbance, $20 \%$ disturbed is light, and $5 \%$ disturbed is trace. Approximately $42 \%$ of the watershed's surface cover has high pig disturbance, $37 \%$ with light pig disturbance, and $9 \%$ with trace pig disturbance. 


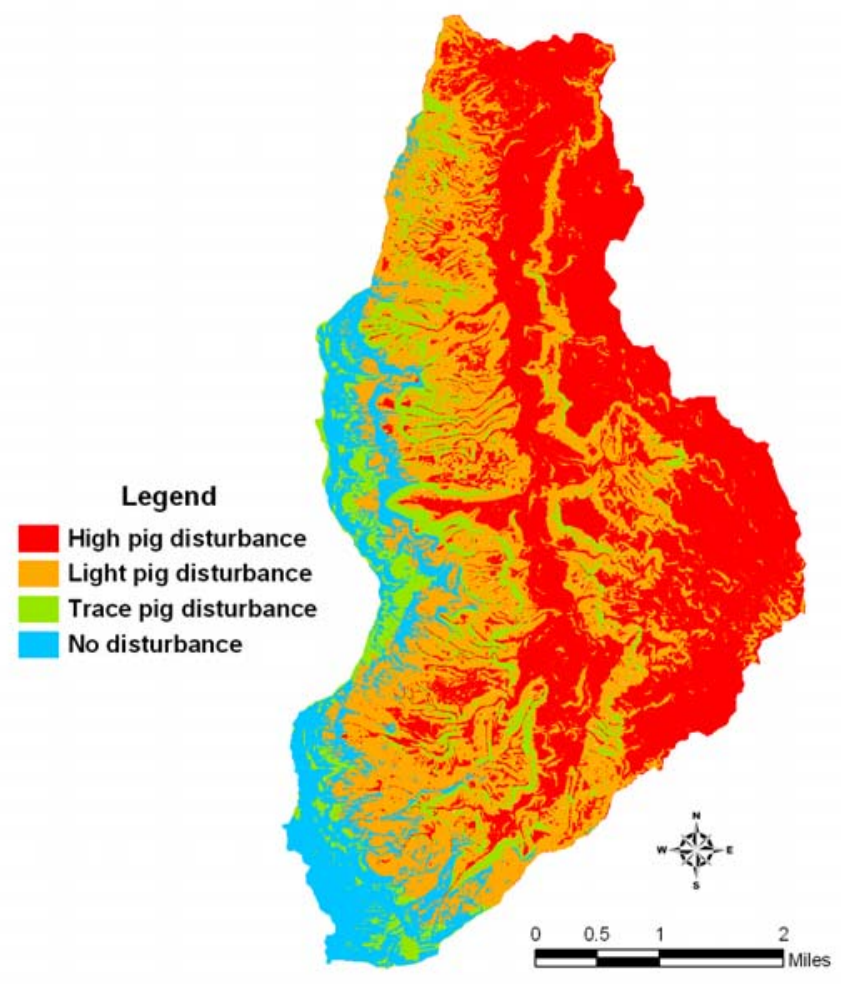

Figure 2. Feral pig disturbance in Hanalei Bay Watershed.

With nearly $90 \%$ of the study area affected by feral pig activity, predicted sedimentation was 4,170 tons or 2.5 times larger than that without pig damage. This substantial increase in sedimentation is expected due to highly sensitivity of the model to the surface residue cover parameter as shown in the sensitivity analysis section of this report. Nearly half of the surface residue coefficients were decreased to below $60 \%$ of their original values when pig damage was not accounted for, which translates to an expected increase in sediment load. These results highlight the need for a more accurate measurement of the impact of pig damage on the residue cover through the watershed. More work is needed to delineate the impacted areas and levels of pig damage. The needed work will evaluate the current methodology used and suggest adjustment to it based on detailed field measurements.

\section{Acknowledgements}

This is an executive summary of a project report submitted by the author to the USDANRCS as part the research project funded through them entitled " Modeling current and alternative best management practices on Hanalei watershed using AnnAGNPS." The author would like to acknowledge the following colleagues, Dudley Kubo, Chris Smith, Katina Hanson, Dan Moore, Fred Theurer and Mike Robotham from NRCS, Jim Jacobi from USGS, Carl Berg from the Hanalei Watershed Hui, Farhat Abbas, Viktor Polyakov and Chui Cheng from University of Hawai i-Manoa. 


\title{
Photographic Time Series of Sedimentation Near the Wall, Hanalei
}

\section{Bay, Kaua i, Summers of 2005 and 2006}

\author{
Mike Field ${ }^{1}$, Hank Chezar ${ }^{1}$, and Curt Storlazzi
}

\section{Introduction}

The USGS Coral Imaging System is used to provide visual documentation of sedimentation on coral surfaces that can then be correlated with measurements of waves, currents, rainfall, and stream discharge. The camera obtains a high-resolution digital still image every four hours ( 4 am, 8 am, noon, 4 pm, 8 pm, midnight) with the time and date recorded. Companion instruments record light penetration, or turbidity, and the camera images show whether the particles actually settled on the bottom or were transported through the region. The camera was deployed in 2005 and again in 2006 on the seafloor offshore of the mouth of the Hanalei River and adjacent to the Wall at a depth of about $10 \mathrm{~m}$. A gridded concrete block was used as a proxy for an irregular coral surface so that estimates of levels of sediment accumulation - and erosion — could be correlated with other measurements and improve our understanding of under what conditions sediment affects corals. The over-all goal was to observe patterns in sediment accumulation and/or erosion on the seabed and coral communities, and relate those observations to synchronous measurements of waves currents, turbidity and stream discharge.

\section{Summer 2005 Results}

The 2005 study showed a slow, steady covering of the flat concrete block by muddy sand within the month of June. Throughout the remainder of the summer there was little change to the amount of sediment. There were, however, apparent changes in texture, as the surface sediment alternately became finer or coarser. The changes on the block surface mirrored changes observed in the adjacent bottom sediment, and appeared to reflect mild reworking by small waves in addition to burrowing/grazing organisms. This is consistent with the low-to-absent wave stresses and very weak currents during the 2005 summer (Storlazzi and others, 2006). The patchiness of the sediment layer on the block surface indicates small amounts of sediment being removed and infilled over short time periods (one day). Their irregularity and randomness indicates that they are more likely caused by feeding patterns of invertebrates than by physical forces.

\footnotetext{
${ }^{1}$ USGS Pacific Science Center, 400 Natural Bridges Dr., Santa Cruz, CA 95060
} 


\section{Summer 2006 Results}

The photographic time series for the summer of 2006, using a new tripod adjustable in the vertical, horizontal, rotational and angular planes, showed a more complex pattern than 2005 , largely as a result of the large volumes of sediment injected into the inner bay during the floods of February and March, 2006, and smaller amounts during the experiment in early August. From the deployment in June 5 until inspection and cleaning on July 10, there was a gradual, continuous build-up of sediment on the block surface, with no evidence of sudden events (deposition or erosion) caused by waves and currents. Adjacent live corals seem to have been unaffected by the mild sedimentation. Between July 19 and July 23 the amount of sediment markedly increased, and this period correlates with a period of increased wave stresses as recorded at the south-central reef and along the inner Wall. The bottom camera captured discharge into the bay following the early August flood of the Hanalei River. Flocculated particles first appeared in the water column between $8 \mathrm{pm}$ and midnight on August 6. Between 4 am August 7 and 4 am August 8, the suspended sediment concentrations were high enough to cause a complete "brown-out." The water remained turbid for the next 48 hours, and finally cleared by 4 am on August 10.

Sediment on the block surface was collected on July 10 and again when the camera was recovered in September. Total dry weight of the sediment covering about $30 \%$ of the block on July 10 was $2.84 \mathrm{~g}$ and was $68 \%$ terrigenous in composition. The sediment accumulation rate over a period of 36 days was $3.5 \mathrm{~g} / \mathrm{m}^{2} /$ day. In September, the block was recovered, and the sediment on its surface and top edge was retained; it was $85 \%$ terrigenous in composition and had a weight of $38.27 \mathrm{~g}$. The sediment accumulation rate over a period of 60 days was $6.0 \mathrm{~g} / \mathrm{m}^{2} /$ day, or nearly twice as great as the first part of the summer.

\section{Summary}

The key observation for 2005 and 2006 - two years with vastly different discharge records - is that sediment covered a block along the base of the Wall within several weeks and the sediment remained on the block for the remainder of the summer, except for minor changes due to small waves and feeding organisms. This information has strong implications for the success of coral recruitment to hard surfaces at this location following the spawning that occurs in summer months as the mantling by sediment eliminates a large number of potential recruitment surfaces.

\section{References}

Storlazzi, C.D., Presto, M.K., Logan, J.B., and Field, M.E., 2006, Coastal circulation and sediment dynamics in Hanalei Bay, Kaua i; Part I - Measurements of waves, currents, temperature, salinity and turbidity; June-August, 2005: U.S. Geological Survey Open-File Report 2006-1085, 35 p. 


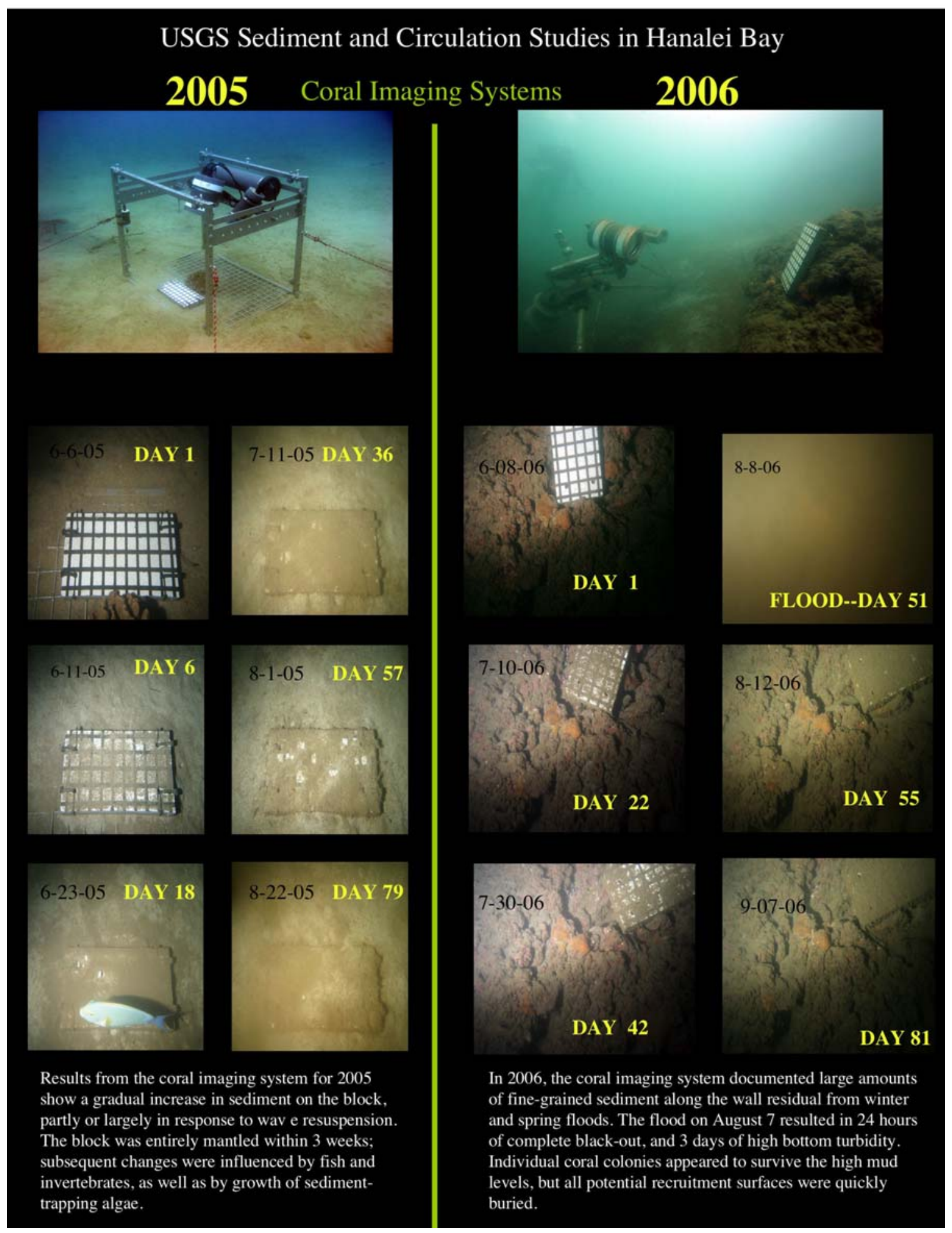




\title{
Resistance and Resilience of a Hawaiian Coral Reef Fish Assemblage
}

\section{to Dynamic Natural Conditions: Hanalei Bay, Kaua i - 1993 to 2005}

\author{
Alan Friedlander ${ }^{12}$ and Eric Brown ${ }^{3}$
}

Coral reefs in dynamic natural environments with limited human impacts allow us to examine how these systems respond to natural disturbance over time. In Hawai i, a limited number of data sets exist to examine the resilience and resistance of coral reef ecosystems to disturbance. Hanalei Bay on the north shore of the island of Kaua'i has been monitored since 1992, providing at unique date set in which to examine changes in the composition of the coral reef community during this time. Hanalei Bay is directly exposed to large winter swells with high surf, as well as frequent heavy winter rainfall and high river discharge.

Fish assemblages were assessed at 20 permanently marked locations using standard underwater visual belt transect survey methods. A SCUBA diver swam each $25 \mathrm{~m}$ x $5 \mathrm{~m}$ transect at a constant speed and identified to the lowest possible taxon, the numbers and sizes of all fishes visible within $2.5 \mathrm{~m}$ to either side of the centerline $\left(125 \mathrm{~m}^{2}\right.$ transect area). Transects were sampled monthly between 1992 and 1994 and then once in 1999, 2003, 2004, and 2005.

Reef fishes in Hanalei Bay demonstrated distinct assemblage structures and characteristics based on specific hard-bottom habitat types. The highest number of fish species was associated with deeper habitats that had high structural complexity. Low numbers of species were observed on reef flats that were distant from sand areas and had low habitat relief. High biomass was also associated with reef-edge habitats and areas with high habitat complexity. Habitats with low spatial relief and limited shelter, particularly when distant from reef edges, were associated with low standing stocks for most fish species.

The higher number of species and biomass at deeper depths is likely the response to the impact of large waves on the shallow reefs and the refuge provided by deeper water. Fishes were more abundant and diverse nearer the reef edge. The sharp interfaces that edges provide between habitats with greatly different physical and biological properties often result in higher movement dynamics and abundance of predators, prey, spawners, and migrators.

Monthly visual fish censuses of transects from December 1992 to November 1994 showed that surf height and degree of wave exposure were negatively correlated with several measures of assemblage organization. Most measures of fish-assemblage structure were lower

\footnotetext{
${ }^{1}$ NOAA, National Ocean Service, National Centers for Coastal and Ocean Science, Biogeography Team

${ }^{2}$ The Oceanic Institute, 41-202 Kalanianaole Highway, Waimanalo, HI 96795

${ }^{3}$ NPS, Kalaupapa National Historical Park, PO Box 222, Kalaupapa, HI 96742
} 
during the winter months when large north Pacific swells and heavy rainfall, coupled with high river discharge, impacted the bay.

Species richness and diversity have remained relatively constant over the 12-year survey period. Biomass has, however, increased by $38 \%$ during this time period. Three introduced species have increased in abundance since 1993 and now account for over $30 \%$ of the total fish biomass in the bay. Increases in total fish biomass since the early 1990s cannot be attributed solely to introduced species, as other elements of the fish assemblage have also increased over this time period. Reduced fishing pressure has been cited as one potential reason for these trends.

The entire fish assemblage, based on numerical abundance, has fluctuated over time with no apparent trend (fig. 1). Assemblage structure in the low-relief and shallow habitats has shown the greater amount of variability while the deep slope and the spur and groove habitats appear most stable. These changes are likely responses to environmental variability, and the relatively intact condition of the fish assemblage compared with other more exploited locations around Hawai i may provide the resistance and resilience to change necessary under harsh and variable environmental conditions.

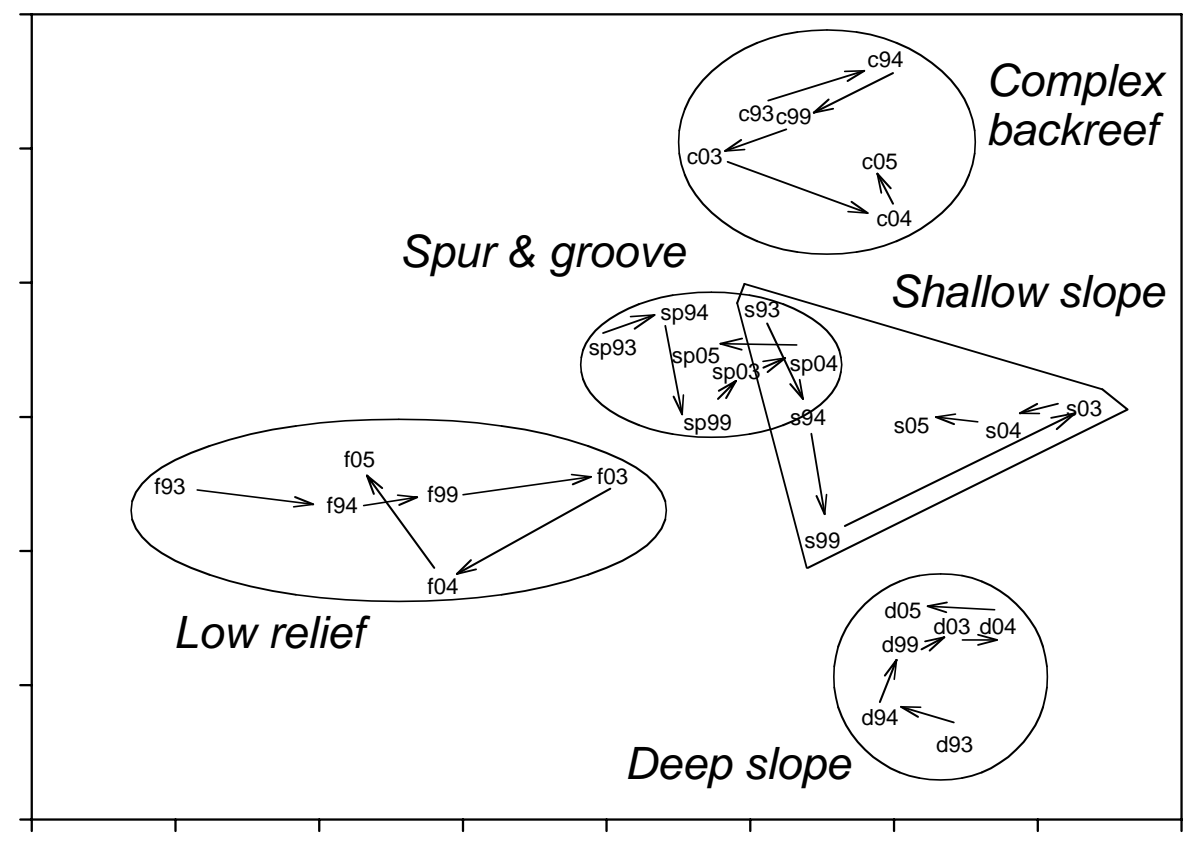

Figure 1. Multi-dimensional scaling plot of reef fish assemblages over time in five major habitats in Hanalei Bay, Kaua i from 1993 to 2005. 


\section{Background References}

Friedlander, A.M. and Brown, E.K., 2005, Hanalei benthic communities since 1992; spatial and temporal tends in a dynamic Hawaiian coral reef ecosystem: Hawai' i Cooperative Studies Unit, Pacific Aquaculture and Coastal Resources Center, University of Hawai i at Hilo, Hawai i Cooperative Studies Unit Technical Report HCSU-003, 32 p.

Friedlander, A.M. and Parrish, J.D., 1998, Temporal dynamics of the fish assemblage on an exposed shoreline in Hawai i: Environmental Biology of Fishes, v. 53, p. 1-18.

Friedlander, A.M. and Parrish, J.D., 1998, Habitat characteristics affecting fish assemblages on a Hawaiian coral reef: Journal of Experimental Marine Biology and Ecology, v. 224, no. 1, p. 1-30.

Friedlander, A.M. Parrish, J.D., 1997, Fisheries harvest and standing stock in a Hawaiian Bay: Fisheries Research, v. 32, no. 1, p. 33-50.

Friedlander, A.M., DeFelice, R.C., Parrish, J.D., and Frederick, J.L., 1997, Habitat resources and recreational fish populations at Hanalei Bay, Kaua'i: Project report by the Hawai i Cooperative Fishery Research Unit to Hawaii Department of Land and Natural Resources. 296 p. 


\title{
Developing Tools for Assessing Land Based-Contamination Impacts in
}

\section{Corals}

\author{
Laetitia Hédouin' and Ruth Gates ${ }^{1}$
}

Coastal development and changes in land use critically threaten Hawai' i's coral reefs. These practices have lead to the contamination of coastal environments with sediment and runoff. This is evident in Hanalei Bay, Kaua i, where coral reefs have been negatively impacted by high sediment loading. The objective of our study is to develop tools for assessing the impact of land-based contamination on coral reefs in Hanalei Bay, one of the priority watersheds identified by the Land-Based Pollution Local Action Strategy of Hawai'i. The goal of this project can only be met by linking the levels of exposure to land based contamination with specific biological behavior in corals in Hanalei Bay. To accomplish this, a detailed understanding of the exact nature of the stressors found in the watershed is required. Therefore, six stations were identified in Hanalei Bay where the species of major interest (Montipora capitata, Porites compressa and $P$. lobata) were present and superficial sediment samples were collected at each location for analyses of grain-size, composition and metalloid and metal concentrations. Then, the following specific objectives will be addressed in Hanalei Bay:

- Monitor turbidity, temperature and salinity at the six sampling stations and deploy sediment traps to measure sediment deposition rates,

- Define the coral community composition at these sampling sites,

- Identify gene targets that are sensitive to, and thus indicative of coral exposure to landbased contamination (e.g. sediment, contaminant) using microarray,

- Characterize histological changes in coral tissues associated with exposure to landbased contamination, and

- Analyze these data to identify the biological trait or traits that most tightly correlate with the levels of land-based contamination exposure in Hanalei Bay.

This work will characterize the quality and quantity of sediments and a range of cooccurring stressors (e.g. contaminants, temperature, salinity, nutrients) in Hanalei Bay, and provide a detailed understanding of how these exposures are reflected in the biology of coral across a range of temporal scales. Sediment specific gene expression profiling will be used to characterize current exposure states in corals; histological analyses will be informative about sediment impacts on corals on a scale of days to weeks, and coral community structure will

\footnotetext{
${ }^{1}$ Hawai i Institute of Marine Biology, PO Box 1346, Kaneohe, HI 96744
} 
reflect sediment impacts on a scale of months to years. Using this multi-scale approach we will define the causal relationship between sediment stress and changes in coral health and identify the most appropriate tool for evaluating these impacts in real time on Hawaiian coral reefs. As such, this project will identify and field test a management relevant tool (or suite of tools) that has the potential to underpin state-wide monitoring of land-based contamination in corals and serve as the rationale for improving land use practices in these areas. 


\title{
Hydrodynamic Modeling of Hanalei Bay
}

\author{
Ron Hoeke ${ }^{1}$ and Curt Storlazzi ${ }^{2}$
}

The fates of sediments, nutrients, pathogens, and pollutants introduced to Hanalei Bay by the Hanalei River, as well as by other streams and groundwater discharges around the bay, are largely unknown. Gaining a spatially explicit understanding of residence times, bed sheer stresses, and overall circulation within the bay under varying conditions would greatly aid in predicting the trajectories of these materials and the water quality of the bay. In order to address these concerns the Delft3D numerical circulation model has been applied to estimate the relative contributions of waves, winds, tides, and river floods on the hydrodynamics of the bay. This model will draw heavily on USGS field data collected during the summers of 2005 and 2006 and from instruments currently deployed over the 2006-2007 winter season. In addition to providing information about sediment processes and water quality, the model will provide insight on larval recruitment and dispersal (are the reefs self-seeding and why has coral recruitment been so high?), as well as the distribution of benthic habitats.

Preliminary results provide insight into the relative contributions of each of the major forcings. Episodic NW swell creates flows and bed shear stresses that are orders of magnitude greater than modal wave conditions, or the contributions from tide and wind. When the model is forced with $3 \mathrm{~m}, 15 \mathrm{sec} \mathrm{NW}$ swell, a condition the bay experiences 30 or more days in an average winter season, depth-average residual flows reach $0.6 \mathrm{~m} / \mathrm{s}$ over the reef flats well inside the bay; bed shear stresses are high over most of the bay's floor; and a well developed jet moves water offshore in the center of the bay (fig. 1A). Conversely, when the model is forced with more modal, summertime conditions, (1 m, $9 \mathrm{sec}$, ENE swell and $5 \mathrm{~m} / \mathrm{s}$ trade winds), flows within the bay are less than $0.1 \mathrm{~m} / \mathrm{s}$ and bed shear stresses in the interior floor of the bay are very low (fig. $1 B$ ). Modeled bed shear stresses remain very low in the area known as the "Black Hole" off the mouth of the Hanalei River through both of the modeled conditions.

Future plans include tuning the model with in situ observations and using components of the model in a near-real-time and forecasting mode to provide public health and safety bulletins for the bay.

\footnotetext{
${ }^{1}$ Joint Institute for Marine and Atmospheric Research (JIMAR), University of Hawaì i, 1000 Pope Rd., Honolulu, HI 96822

${ }^{2}$ USGS Pacific Science Center, 400 Natural Bridges Dr., Santa Cruz, CA 95060
} 


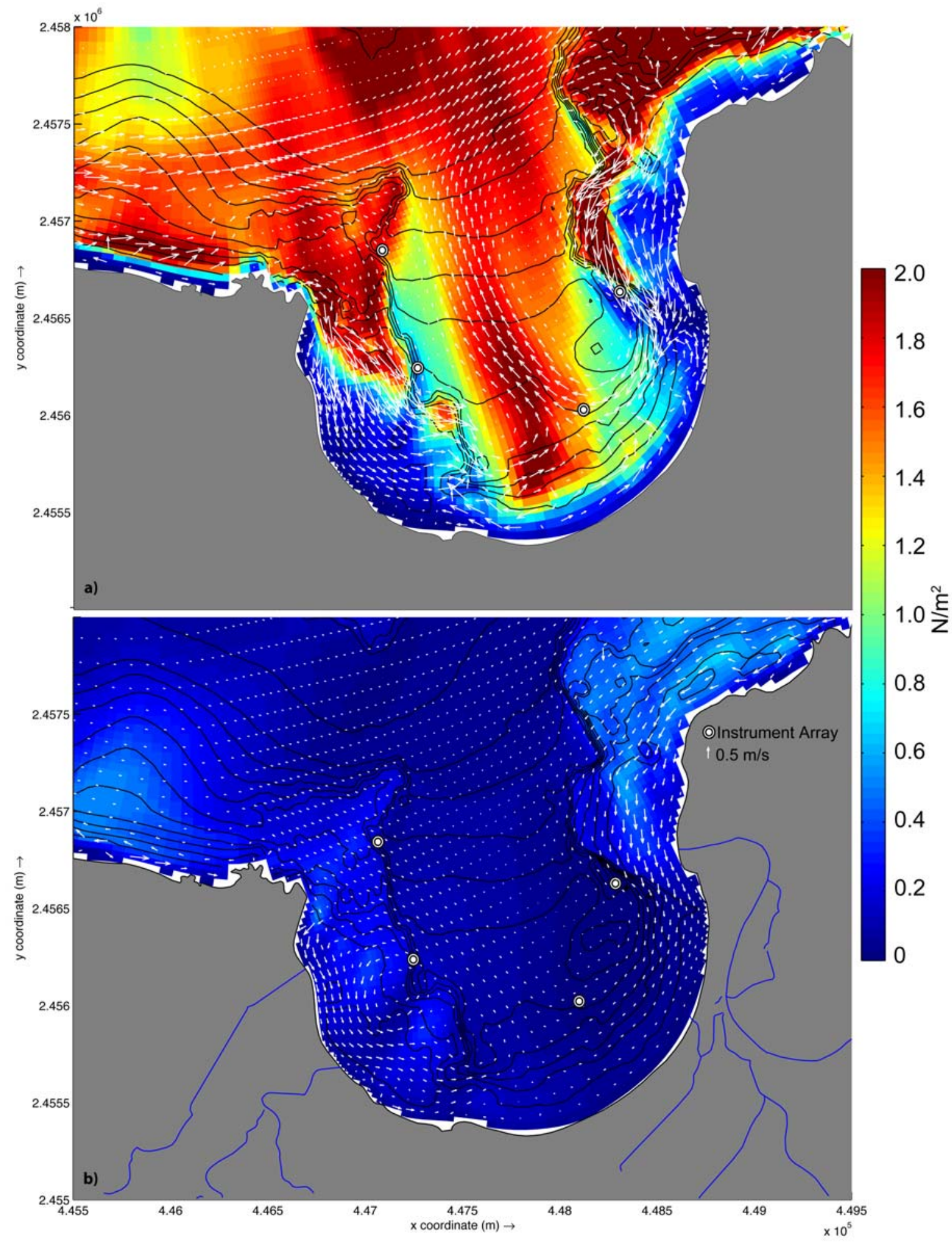

Figure 1. Modeled depth-averaged current velocities (white arrows) and bed shear stresses at Hanalei Bay; A) $5 \mathrm{~m} / \mathrm{s}$ ENE wind, $3 \mathrm{~m}$, $15 \mathrm{~s}$ period, NW swell; $B) 5 \mathrm{~m} / \mathrm{s}$ ENE wind, $1 \mathrm{~m}, 9 \mathrm{~s}$ period, ENE swell; instrument arrays in both $A$ and $B$ are indicated. 


\title{
Mapping Plant Species and Communities in the Hanalei Watershed
}

\author{
Jim Jacobi' and Stephen Ambagis ${ }^{2}$
}

The focus of this project was to produce a detailed map depicting the distribution of native and alien plant communities and selected invasive species for the Hanalei watershed on the island of Kaua i. This vegetation map will serve as one basis for sampling, analyzing, and interpreting other ecological data collected in this area relative to erosion and fine sediment transport through the watershed.

Plant communities within the Hanalei watershed were mapped using spectral analysis of digital images. The imagery for this classification was collected by the Quickbird satellite on January 5, 2004 and April 28, 2003. These images have four spectral bands plus a panchromatic (black and white) band, and spatial resolution (pixel size) of 2.6 meters for the multi-spectral data and $0.5 \mathrm{~m}$ for the panchromatic band. The analysis was primarily conducted using an object-based classification program called eCognition. The advantage of using an object-based classification program is that it allows for the incorporation of spectral as well as size, shape, and textural components of the data into the analysis.

To facilitate fieldwork in the watershed, we established a total of 15 sites (Landing Zones or LZs) where we could land a helicopter. The $15 \mathrm{LZs}$ served as focal points for conducting the plant studies, as well as for many of the other terrestrial components of this research program. Most of the LZs were located along the main stream channel, but two of the sites were in hanging valleys that included tributaries that fed into the main Hanalei River. Plant sampling included establishing ground-truth plots that were used to calibrate the digital analysis of plant communities on the satellite imagery, and a set of 38 formal vegetation sampling plots to characterize the composition and structure of the mapped plant communities. We also collected data on the distribution and intensity of ground disturbance caused by feral pigs throughout many parts of the watershed.

A total of 26 plant communities and species were mapped within the Hanalei watershed (fig. 1). Given the extremely high resolution of the satellite imagery, the vegetation map displays both community and species units. Most of the native-dominated plant communities currently found within the Hanalei watershed are above 2,500 ft elevation, particularly on the upper western side of the valley. However, the vast majority of the Hanalei watershed is currently dominated by alien species. This is likely due to the rapid invasion of this area by several alien plant species, particularly following major damage to the native plant communities during hurricanes Iwa and Iniki in 1982 and 1992, respectively. Much of the valley floor and the lower slopes above the river are dominated by guava with an understory

\footnotetext{
${ }^{1}$ USGS Pacific Island Ecosystems Research Center, Kilauea Field Station, Hawai i National Park, HI 96718

${ }^{2}$ USGS Hawai i Cooperative Studies Unit, University of Hawai i at Hilo/PACRC, Kilauea Field Station, Hawai`i National Park HI 96718
} 
of Clidemia and Lantana. It also appears that several highly invasive plant species, including Albizia, Australian treefern, strawberry guava, Malabar melastome, and rose myrtle, are rapidly increasing in both distribution and abundance across the lower part of the watershed.

Any use of trade, product, or firm names in this presentation is for descriptive purposes only and does not imply endorsement by the U.S. Government.

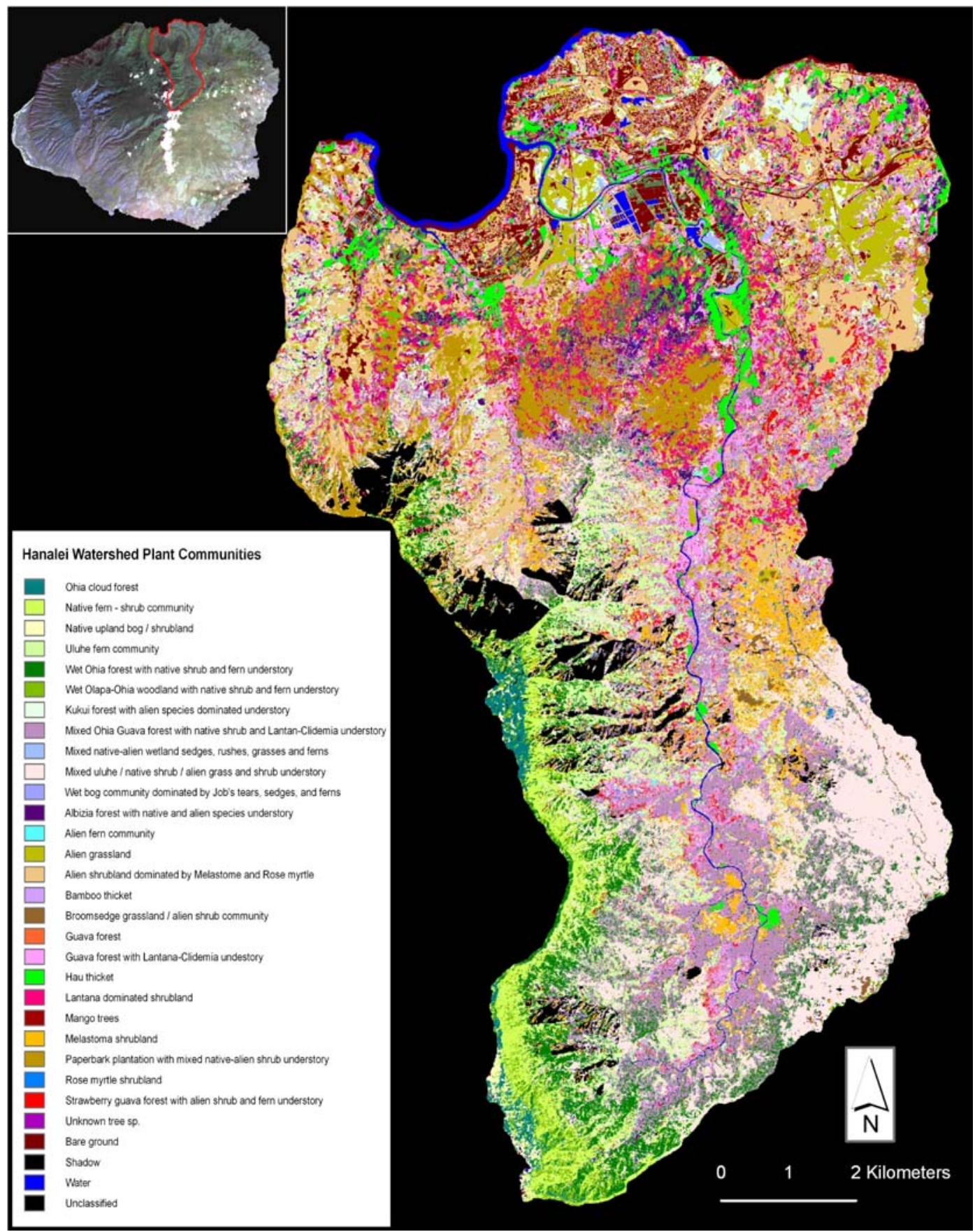

Figure 1. Plant communities mapped within the Hanalei watershed. 


\title{
Impact of Sediment, Storm Waves and Storm Floods on Hawaiian Reef
}

\section{Communities}

\author{
Paul Jokiel $^{1}$
}

Major storms are infrequent events of high intensity and short duration that can exert a profound influence the structure of Hawaiian reefs. Extreme wave energy directly damages corals and retards coral community development. A paradox is that storm surf also represents a positive factor that maintains vitality of many communities through the mobilization and removal of terrigenous, calcareous and organic sediments that otherwise will smother a reef system. Flood events erode watersheds and deposit sediments on the reefs that can kill corals and block recruitment of new coral colonies. Fresh water delivered by storms also can lower local salinity to levels that are lethal to corals and other reef organisms. Nutrients and pollutants associated with fresh-water runoff are transported onto coral reefs during such storms. The impact of these events is poorly understood for several reasons. These events are transient in nature and seldom are observed directly on reefs due to difficulties in making observations during conditions of extreme wave motion or turbidity. The duration of most coral reef investigations is too short to allow evaluation of the major storm events that occur with a frequency of decades to hundreds of years. The pattern of impact for a major storm is highly complex, and influenced by local bathymetry, shoreline topography and directionality of the storm event. Nevertheless, sufficient data are available to provide a general spatial and temporal description of the relative importance of major storm waves and storm floods on reefs throughout the main Hawaiian Islands. Recent studies at Pila`a reef on the northeast coast of Kaua i provide insight into the dynamic changes brought about by poor land management and the subsequent recovery period of the coral reef community. The relative impact of wave damage, damage due to terrigenous sediment runoff and damage due to factors associated with fresh water are summarized for the major Hawaiian coral reef habitats in relation to questions being developed for the ongoing research program at Hanalei Bay.

1 University of Hawai i, Coral Reef Assessment and Monitoring Program, Hawai i Institute of Marine Biology, PO Box 1346, Kaneohe, HI 96744 


\section{Submarine Groundwater Discharge in Hanalei Bay: Impacts on}

\section{Coastal Water Quality}

Karen Knee', Blythe Layton², Alexandria Boehm², Joseph Street', Carl Berg², and Adina Paytan'

Submarine groundwater discharge (SGD) represents a potentially important, but poorly quantified, source of freshwater, nutrients and pollutants to the coastal ocean. In Hanalei Bay, high fecal indicator bacteria (FIB) counts, particularly after heavy rains, raised suspicions that sewage was leaching into groundwater and discharging directly into the bay. This study, conducted in March 2005 and August 2006, used radium, a natural groundwater tracer, in combination with salinity, to characterize groundwater mixing and discharge in this area and assessed the importance of groundwater as a source of nutrients and pollution to the surf zone. When radium activity was plotted against salinity, a three-endmember mixing system consisting of fresh groundwater (low salinity, low radium), saline groundwater (high salinity, high radium), and seawater (high salinity, low radium) became apparent. Groundwater sampled from temporary wells in the beach face revealed that the coastal aquifer is a dynamic zone in which these three endmembers mix. A small, but noticeable, salinity depression occurred near shore in areas not located near a stream or river, indicating the discharge of freshened groundwater (fig. 1).

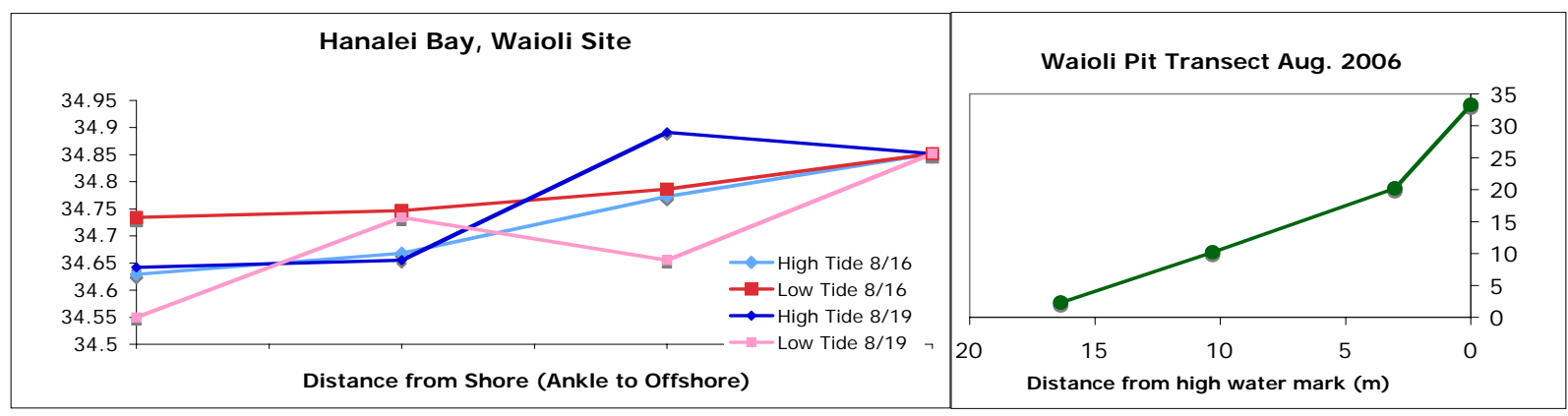

Figure 1: Example of salinity gradient in groundwater and nearshore, Waioli Beach.

Concentrations of all nutrients measured (nitrate+nitrite, phosphate, silicate, and ammonium) were higher in groundwater than in nearshore water, and concentrations of nitrate+nitrite were higher in groundwater than in any other water sampled, including streams

\footnotetext{
${ }^{1}$ Stanford University, Department of Geological and Environmental Sciences, 450 Serra Mall, Braun Hall, Bldg. 320, Stanford, CA 94305-2115

${ }^{2}$ Stanford University, Department of Civil and Environmental Engineering, Terman Engineering Center, M 42, Stanford, CA 94305-4020

${ }^{3}$ Hanalei Watershed Hui, PO Box 1285, Hanalei, HI 96714
} 
and the Hanalei River (fig. 2). This indicates that groundwater could be an important nutrient source to nearshore waters in Hanalei Bay. High variability within sample groups (groundwater pits, nearshore, Hanalei River, streams and Hanalei open bay) illustrates that these classifications, especially groundwater, represent a complex mixing zone rather than a uniform end member.
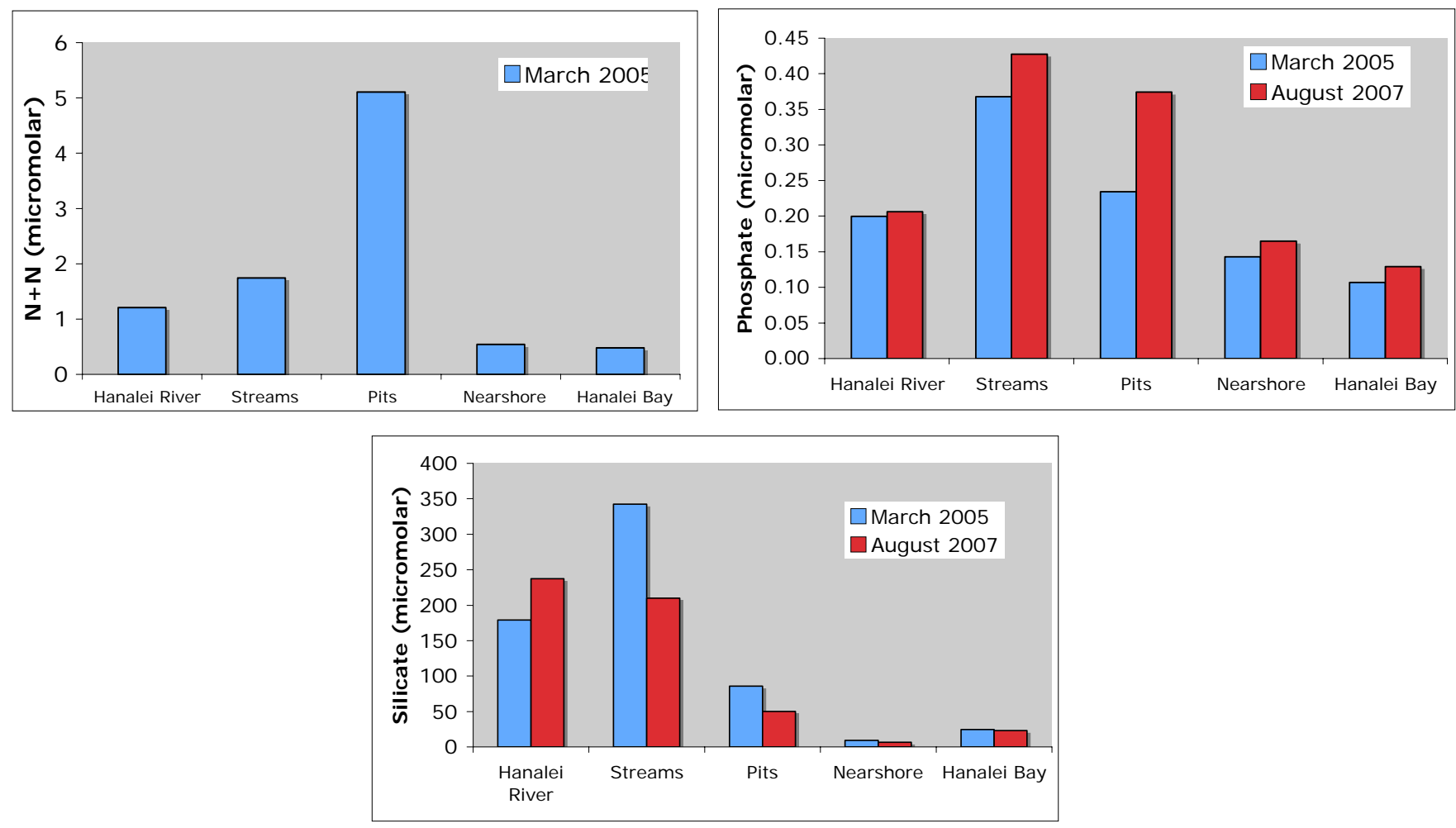

Figure 2: Nutrient concentrations at various site types, Hanalei Bay, March 2005 and August 2006

Fecal indicator bacteria (total coliform, E. coli, and Enterococcus) were measured in the Hanalei River, streams, groundwater and the nearshore zone. Most samples were below the detection limit for these bacteria; however, the bacteria were detected in all samples collected at the Queen's Bath spring in Princeville (fig. 3). The highest levels of all fecal indicator bacteria tended to occur in streams; however, the fact that fecal indicator bacteria were observed in some groundwater samples merits further investigation. A small subset of sites from the August 2006 sampling were screened for the presence of a human-specific Enterococcus marker, the esp gene. One hundred percent of the samples screened $(\mathrm{n}=4)$ were positive for the marker. This indicates that at least a portion of the bacteria present at these sites originated from sewage. The presence of this marker strongly supports the need for further study of fecal contamination at Hanalei Bay.

Future work will focus on calculating SGD-related fluxes of water and nutrients to the coastal ocean, investigating the efficacy of caffeine as a wastewater indicator in this area, 
assessing the influence of land use on nutrient subsidies from SGD, using Ha'ena, Hanalei, and Princeville as comparison sites, and tracking the source of fecal indicator bacteria entering the bay using the esp gene.
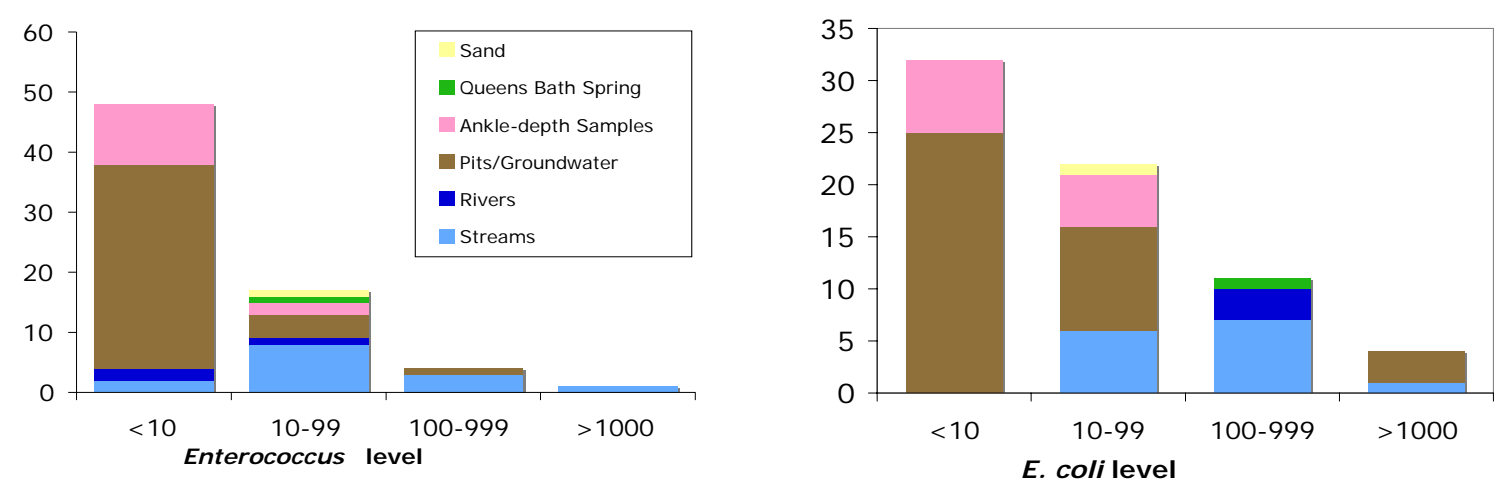

Figure 3: Fecal indicator bacteria in the Hanalei Bay area. The $\mathrm{x}$-axis divides samples into order of magnitude class, and the y-axis shows the number of individual samples falling into each class. 


\title{
Hanalei Bioassessment Survey
}

\author{
Linda Koch ${ }^{1}$
}

The Hawaii State Department of Health's methodology of determining ecosystem health employs a holistic approach that evaluates the entire watershed as an extended ecological unit. Instead of simply evaluating specific points along the stream to determine species composition and abundance, we consider multiple lines of evidence to determine the health of the entire system. These lines of evidence include the habitat available for various species, both native and introduced, riparian zone integrity and composition, erosion evidence, bottom types, water chemistry, as well as, information regarding previous studies, water use, land use and classification.

Visits utilizing the Hawai i Stream Bioassessment Protocol (HSBP) were conducted between August 29, 2006 and September 1, 2006 on 4 sites in Hanalei watershed. Two lower sites and two upper sites were accessed by helicopter. The assessments were conducted on relatively sunny days with a few light rain showers.

Previous investigations from researchers indicate a significant population of introduced species including several predacious species. Results from the assessments indicate that a relatively good aquatic community was present in the watershed. Overall species composition was favorable, but habitat was somewhat degraded in the lower sites.

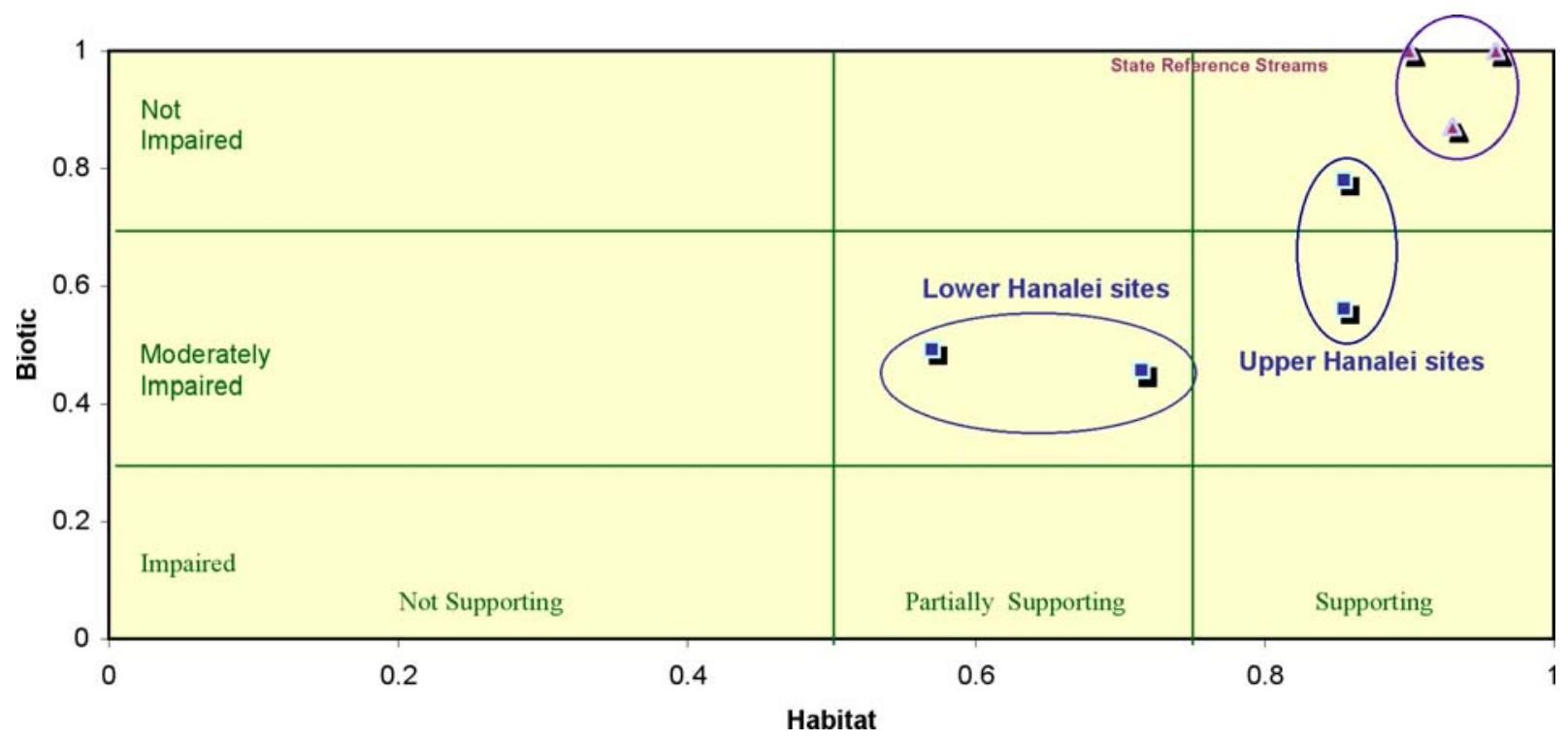

\footnotetext{
${ }^{1}$ Hawaii State Department of Health, Environmental Planning Office, 919 Ala Moana Blvd., Rm. 212, Honolulu, HI 96814
} 


\title{
USDA Natural Resources Conservation Service Assistance to Hanalei
}

\author{
Dudley Kubo'
}

The designation of Hanalei as an American Heritage River by President Clinton, in July 1998, directed federal agencies to extend their existing programs to the Hanalei community. The NRCS authorized the start of a Cooperative River Basin Study for the Hanalei River, which funded NRCS staff and permitted NRCS to cooperate with other Federal, State, and local agencies in making investigations and surveys. Through the River Basin study and other authorities, NRCS has provided assistance to the community, through the Hanalei Watershed Hui, in many forms, including the following:

- NRCS has assisted with watershed modeling to develop sediment discharge estimates from the undeveloped upper watershed areas. In 2003, national technical support was obtained for the application of the USDA's Annualized AGricultural Non-Point $\underline{\text { Source }}$ Pollution Model to the Hanalei Watershed. AnnAGNPS is a continuous simulation, surface-runoff, pollutant-loading model, which subdivides the watershed into cells of homogeneous soil type, land use, land management, and precipitation. The difficulties of applying the continental, agricultural watershed model to the tropical island watershed were many. Cell processes include precipitation, runoff, soil moisture balance, crop condition and management, and soil erosion. In the Hanalei Watershed, the areal divergence in rainfall required development of numerous climate datasets to account for rainfall variability. Topographic relief in the Hanalei Watershed is extreme which complicated application of the Revised Universal Soil Loss Equation for sediment yield. Landslides and debris flows in the steep upper watershed areas are frequent and are considered to be significant contributors to stream sediment. Published analytical and empirical coefficients for soil loss and runoff computations are generally unavailable for the soil, vegetation, and land management conditions in the Hanalei Watershed.

- Through a convergence of programs and funding sources which included the HWH, EPA, USGS Biological Resources Division, USGS Water Resources Division, University of Hawai i, and NRCS, detailed data for soils, vegetation, erosion factors, and hydrology were collected. A refined watershed model with the updated information is being implemented. Continued national support for AnnAGNPS development has been assured. The model outcomes will be used to develop tailored and targeted treatments in the watershed to reduce sediment discharge to the estuary, sandy beaches, and coral reefs.

- $\quad$ NRCS participated with the East Kaua i Soil and Water Conservation District to fund operation of the USGS sediment gage on Hanalei River during the 2006 federal fiscal

\footnotetext{
${ }^{1}$ USDA Natural Resources Conservation Service, PO Box 50004, Honolulu, HI 96850-0050
} 
year. The sediment gage had operated in 2004 and 2005 with grant funds acquired by the Hanalei Watershed Hui. The additional year of sediment discharge data included a period of prolonged rainfall, which proved valuable in the calibration of the AnnAGNPS watershed model.

- In 2002, NRCS provided funds for travel and expenses for a UH Department of Urban and Regional Planning graduate planning practicum to provide assistance to the Hanalei community. The twelve students and their instructor, Dr. Luciano Minerbi, researched and analyzed using a planning framework three issues: treatment options for wastewater, coexistence of taro lo'i (patches) and endangered waterbirds on the USFWS refuge, and compatibility of tourism and environmental quality. The Practicum Report now serves as a valuable resource for the community.

- The NRCS Lihue field office has a long history of providing technical and financial assistance directly to Hanalei area agricultural producers, especially through the 2002 Farm Bill programs. Recent activities include working with taro farmers to design and implement new lo $i$ and replace existing leaking ditch systems and inferior water control structures with PVC pipe and new water delivery gates. The Field Office staff members have also worked with individuals and groups to enhance and restore wetland habitat types for the benefit of endangered waterbirds. 


\title{
Options for the Disposal of Wastewater Effluent in Hanalei, Hawai i
}

\author{
West Marrin ${ }^{1,2}$
}

For purposes of this review, wastewater disposal options are limited to secondary- and tertiary-treated effluent because the disposal of primary-treated effluent via ocean outfall systems, which are utilized elsewhere in Hawai' $i$, is not anticipated to be practical. The advantages of a tertiary-treated wastewater effluent over those of a secondary-treated effluent include a reduction in (1) suspended and dissolved solids, (2) soluble nutrients, (3) degradable organic carbon $\left(\mathrm{BOD}_{5}\right)$, and (4) some dissolved metals. Currently, both a conventional wastewater treatment facility (perhaps a large packaged plant) and some type of constructed wetland are under consideration. Given that the populated sections of Hanalei have been classified as a natural wetland, it seems unlikely that a "constructed" wetland system could be permitted. In lieu of constructing treatment ponds in native soils, enclosed structures known as living machines could be placed into the ground. Living machines reportedly emulate processes that occur within constructed wetlands and are able to utilize local plants and microorganisms to treat wastewater.

The most obvious option for wastewater effluent is direct discharge into one or more of the surface waters running through the Hanalei watershed. This option would be restricted to the Hanalei River due to intermittent flows in the smaller streams; however, the potential problems with this option are many and varied (e.g., restrictions on NPDES permitting for a "Heritage River" and limitations on effluent disinfection because of the toxicity to aquatic organisms). For environmental, political, aesthetic, and countless other reasons, surface water discharge does not appear to be a viable option.

A second option for treated wastewater disposal is groundwater injection, whereby treated effluent is introduced into saline (and presumably unusable) waters underlying the shallower freshwater lens. Although the USEPA is a decade into the process of banning groundwater injection that disposes both hazardous substances and untreated (or slightly treated) sewage, one of the few remaining permissible uses is the discharge of secondary or tertiary treated wastewater. The EPA refers to these permissible injection wells as Class $V$ Sewage Treatment Effluent (STE) wells, which are permitted individually in the state of Hawaii for treatment plants that receive only sanitary sewage (i.e., no hazardous wastes). This requirement could be met in Hanalei thanks to the absence of industrial facilities connecting to the proposed sewer system. However, the public often associates groundwater injection wells with unanticipated and undesirable consequences, as was exemplified by two STE wells on Maui that were suspected of contributing to increased nitrate levels in nearby surface waters.

The third option for the discharge of wastewater effluent from small treatment works (either conventional or constructed wetland) is direct land application-preferably on a plot

\footnotetext{
${ }^{1}$ Water Sciences \& Insights, PO Box 272, Hanalei, HI 96714

${ }^{2}$ Hanalei Watershed Hui, PO Box 1285, Hanalei, HI 96714
} 
located adjacent to the treatment facility. This option usually incurs relatively low construction and maintenance costs, and the infiltration of effluent through shallow soils essentially adds a polishing step to the treatment process (i.e., filters out suspended solids, adsorbs some metals, reduces nutrients via nitrogen and phosphorus uptake by soil microbes). While land application is optimal for some geographic regions, there are a number of papers in the scientific literature that document the degradation of native soils and biota (both macro and micro) on plots used for the land application of wastewater effluent. A further loss of native vegetation to opportunistic species, a gradual change in the chemistry and permeability of soils, a climate characterized by heavy rainfall events, and a shallow groundwater table could render this option a controversial one for Hanalei.

The final option for the disposal of wastewater effluent is reuse, whereby effluent is used to irrigate lawns, golf courses, or (less frequently) food crops. While there are several locations in Hanalei town that could be irrigated using treated effluent, the costs of constructing a delivery network could be high. Perhaps the effluent network could be laid when the sewer laterals are connected to Hanalei households and businesses. The dominant use of irrigation water in Hanalei is for cultivating taro; hence, taro fields represent the most logical destination for reclaimed effluent. Most studies on the use of reclaimed effluent for crop irrigation have focused on conventional growing techniques (i.e., applying water to the ground surface and permitting it to infiltrate). Because the dominant method of taro cultivation in Hanalei includes flooding the crop (i.e., similar to rice cultivation), human contact with irrigation water is extensive. Consequently, there would have to be a major emphasis on disinfecting the water via ozone, UV, or a similar technique before it was delivered to farmers. On a positive note, the requirement for reducing soluble nutrients and dissolved organic matter (constituting the very ingredients of fertilizers that are used on taro) in the effluent might be reduced. Whether the effluent was used to flood taro fields or to irrigate landscaped areas, one could encounter public resistance if people were uncomfortable with the standards and methods of disinfection. 


\title{
Climate Data Input to Modeling the Hanalei Watershed
}

\author{
Daniel Moore'
}

Watershed modeling with the intention of informing water-quality decisions always depends on a hierarchy of data needs. On this blue-green water planet no one involved with the environment doubts that often the first questions about what drives landscape change should be "precisely how much is the precipitation, precisely where, and precisely when?" Estimates of sedimentation and routing of nutrients, pesticides, and microorganisms, depend on these questions.

While much progress has been made in data collection and climate monitoring in the last decade, most watersheds remain under-observed. Any statistical use of historic data depends on sufficient records, those being at least a decade long. Some watersheds, Hanalei included, have elevational relief, which throws uncertainty into the geographic extent that point measurements may be taken to approximate.

This abstract summarizes the effort to adequately characterize the spatial distribution of climate input to the watershed model AGNPS. While the model requires solar radiation, temperature (max, min, and dewpoint), and wind speed, the geographic variation of these data types is not as critical as that of the precipitation. The use of AGNPS in other watersheds has shown that model calibration using observed streamflow and/or sediment data is greatly restricted without adequate spatial distribution of observed precipitation. However, the primary intended use of AGNPS is not in matching short-term observations, such as for example, single storm events or any given month's sedimentation, but rather to provide a gauge of the longer-term consequences of conservation measures, over, say, multiple decades. The measures accomplish this by effecting the short-term, obviously, and the model tracks day-to-day effects, but an attempt to closely match observed data at this time scale is generally not fruitful.

Two long-term precipitation and temperature data-collection sites exist in the Hanalei vicinity. Mt. Waialeale, at the top of the watershed, elevation 5148 feet, and Princeville Ranch, elevation 345, near the outlet provide sufficient data to make reliable statistical estimates of the climate at those stations. Regression analysis between the two sites for time periods of a day, week, or month, show that there is absolutely no relationship for precipitation. Standing in the rain at Princeville Ranch, one could only venture a wild guess at what is happening on Mt. Waialeale. NRCS has shepherded an important effort, the PRISM project, to analyze a nationwide dataset and provide maps and tables of spatial distribution on a monthly and yearly basis. The adequacy of the

\footnotetext{
${ }^{1}$ NRCS National Water Quality \& Quantity Team, 1201 NE Lloyd Blvd., Ste. 1000, Portland, OR 97232
} 
PRISM methodology for Kaua $i$ is questionable. However, the University of Hawai $i$ has done similar work which may be considered at least a step better than the PRISM results for Kaua i. Figure 1 shows isohyets of one month's average rainfall on the north side of Kaua`i, Hanalei in yellow.

The relatively unique orthographic layout of the Hanalei gives insight into why the two precipitation sites might be expected to bear no relationship. Mt. Waialeale is such a high and sudden "poke" of land into an atmosphere that, for thousands of miles around, has seen nothing but flatness. It effectively causes its own precipitation. The Hanalei riverbed slope steepens fairly gradually over the lower 12.5 river miles from sea level to 1,200 ft. From that point, the elevation jumps almost 4,000 ft in the remaining 2.5 river miles.

An examination of the Univ. of Hawai i isohyets for each of the twelve months shows a similar pattern, with closer contours at the upper end of the basin. For AGNPS, then, we can relate zones 9-13, 16, and 17 (fig. 1) to the Waialeale station, and the remaining zones to Princeville Ranch. Using the climate generation algorithms of GEM6 (A USDA Agricultural Research Service tool) one hundred years of statistically valid precipitation and temperature data were generated for Mt. Waialeale and Princeville Ranch. For better spatial distribution, secondary climate data streams were obtained for the 17 zones in figure 1 . The daily precipitation amounts at each zonal centroid were obtained by proportioning the known station data using each month's rainfall isohyets.

Very little can be done in the short term to improve upon this methodology. However, data from the recent within-basin precipitation-collection sites installed by the Hanalei Hui may be more immediately useful to help determine the adequacy of proportioning with the monthly isohyets. Installation of an NRCS climate station (as part of the Soil-Climate Analysis Network) would have similar benefit. 


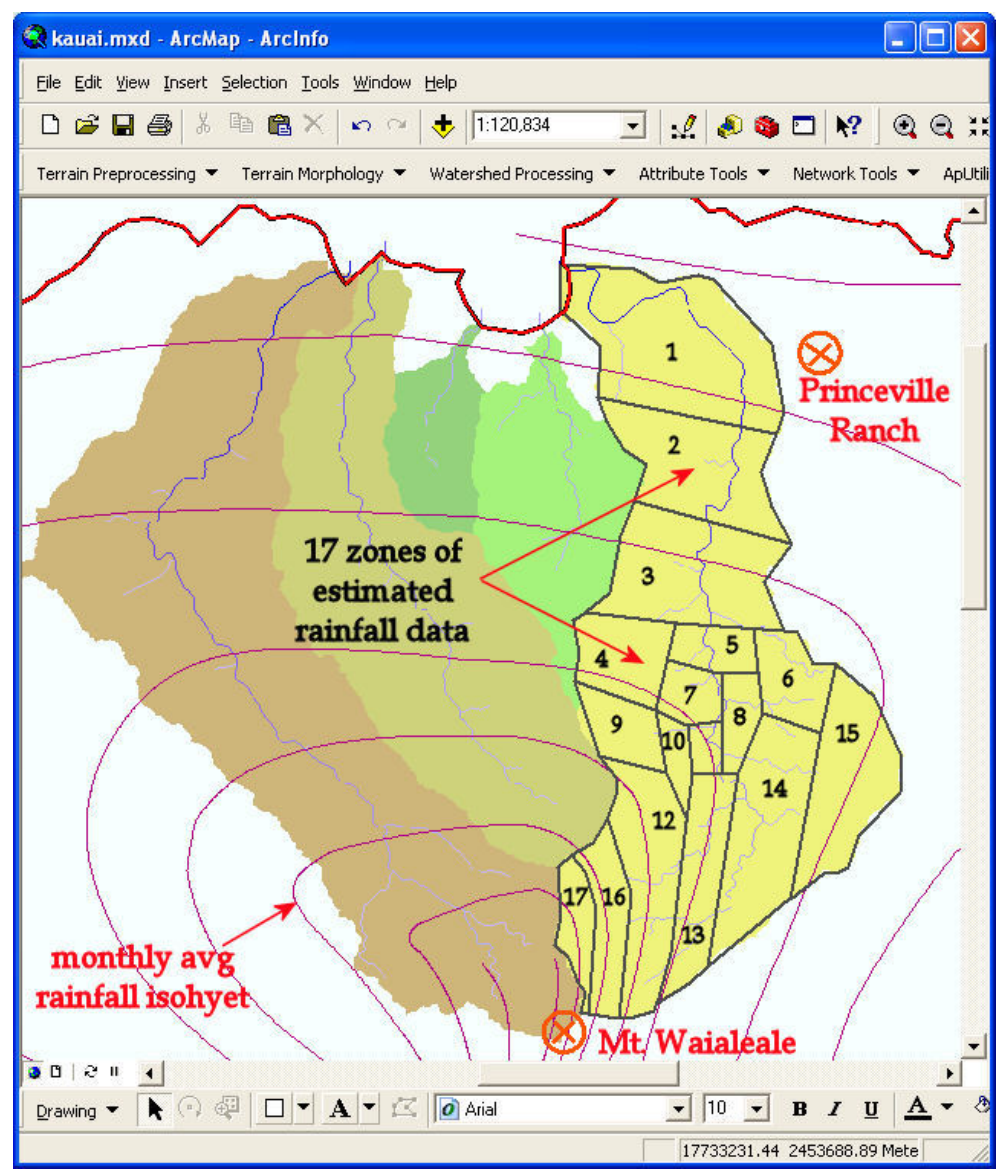

Figure 1. Hanalei climate zones in AGNPS. 


\title{
Survey of Chemical Contaminants in the Hanalei River, Kaua i,
}

\section{Hawai i, 2001}

\author{
Carl Orazio', Thomas May', Robert Gale', John Meadows', William Brumbaugh', Kathy \\ Echols', William Steiner ${ }^{2}$, and Carl Berg ${ }^{3}$
}

The objective of this study was to assess chemical contamination of the Hanalei River as a benchmark for future assessments. Agricultural, urban, and tourism-related activities are potential sources of contamination of the Hanalei's watershed. In December of 2001, samples were collected from a reach of the river near its mouth at Hanalei Bay and from an upstream reach at the Hanalei National Wildlife Refuge. Samples of water, fish (Eleotris sandwicensis, the native Hawaiian O`opu akupa), freshwater clam (Corbicula fluminea), Samoan crab (Scylla serrata), and streambed sediment were collected. The samples were analyzed for common urban and agricultural organic contaminants including organochlorine pesticides, polychlorinated biphenyls, and polycyclic aromatic hydrocarbons and for sixty elements including toxic elements such as copper, zinc, cadmium, tin, mercury, lead, arsenic, and selenium. Organic contaminants were solvent-extracted from the samples and enriched for gas chromatographic analysis with electron capture or mass spectrometric detection. Samples for element analysis were digested and prepared for inductively coupled plasma- spectrometry or quantitative atomic absorption spectroscopy.

Our study found that concentrations of the organic contaminants and toxic elements were very low in the Hanalei River samples. No polycyclic aromatic hydrocarbons, polychlorinated biphenyls, or pesticides other than dieldrin (found at 1-2 parts per trillion) were detected in the water. Very low levels of dieldrin, ranging from 15 parts per billion (ppb, wet weight), and chlordane ( $<0.3$ to $2.1 \mathrm{ppb}$ ) were detected in fish and crabs from the downstream reach: These pesticide residues are likely from past use to control formosan subterranean termites. Polychlorinated biphenyls were not detected $(<50 \mathrm{ppb})$ in the biota samples. Concentrations of toxic elements in the biota were unremarkable. In the sediments, low levels of polycyclic aromatic hydrocarbons $(<3$ - $190 \mathrm{ppb}$ ) indicative of combustion sources were detected at the downstream reach. No pesticides or polychlorinated biphenyls were detected in the sediments, and arsenic, selenium, copper, zinc, cadmium, tin, mercury, and lead were low in concentration and below thresholds of ecological concern.

\footnotetext{
${ }^{1}$ USGS Columbia Environmental Research Center, 4200 New Haven Road, Columbia, MO 65201

${ }^{2}$ University of Hawai $i$ at Hilo, College of Agriculture, Forestry \& Natural Resource Management, 200 W. Kawili Street, Hilo, HI 96720

${ }^{3}$ Hanalei Watershed Hui, PO Box 1285, Hanalei, HI 96714
} 
Concentrations of the organic contaminants and toxic elements targeted by this study were below probable adverse effects levels set by the US-EPA for aquatic organisms. Assessment of other classes of organic chemical contaminants, such as chemicals associated with wastewater treatment effluents, chemicals used in right-ofways and golf courses, pharmaceutical and personal care products, and other chemicals of emerging concern, would provide additional information for assessing potential impacts of contaminants on the Hanalei River.

A full report, entitled Survey of Chemical Contaminants in the Hanalei River, Kaua i, Hawai i, 2001, is available online at http://pubs.usgs.gov/sir/2007/5096/.

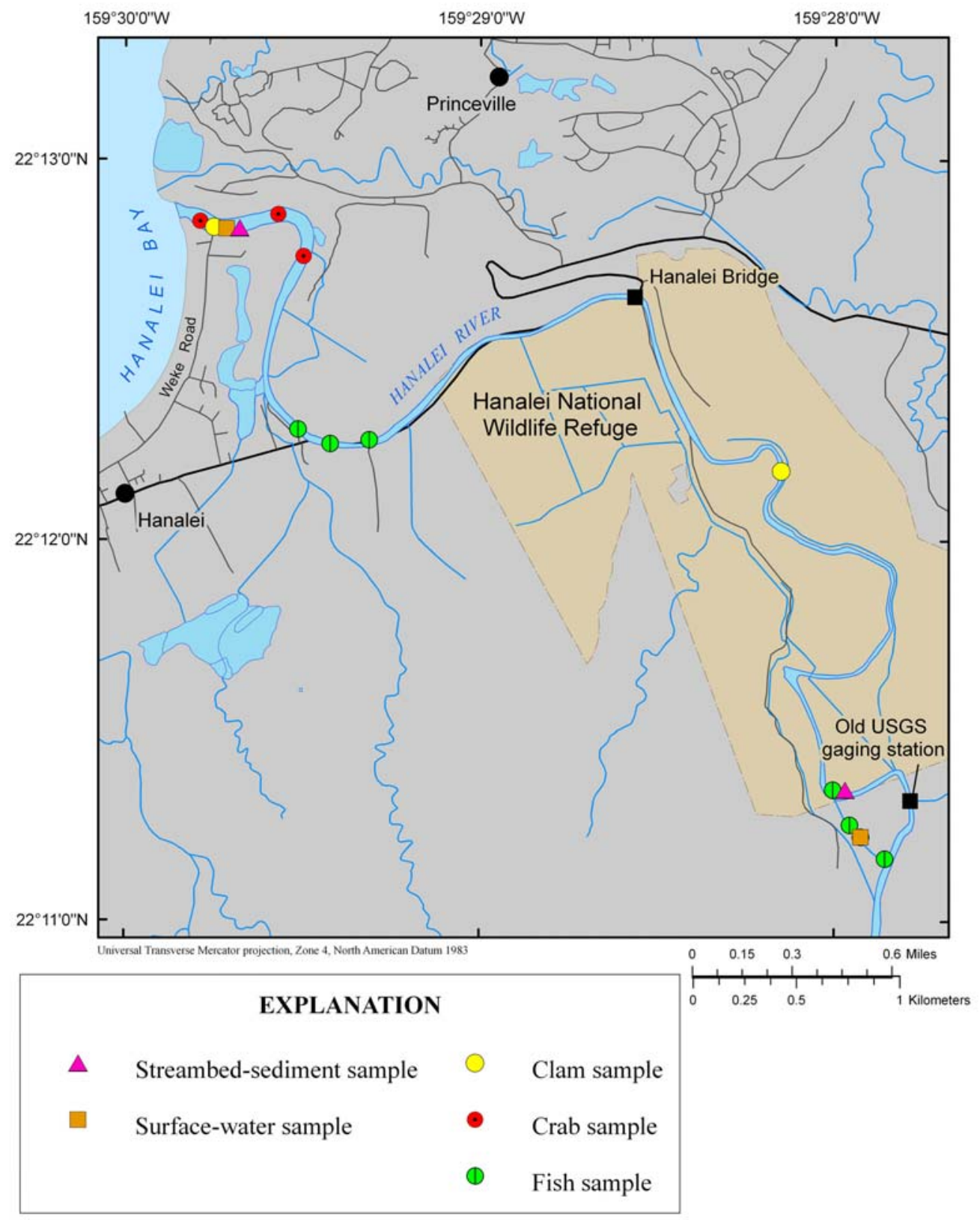




\title{
Soil Sampling for Cesium-137 and Observations of Streambank
}

\section{Erosion in the Hanalei River Watershed}

\author{
Paul Pedone ${ }^{1}$
}

This work was started as an effort to contribute to the AnnAGNPS modeling of the Hanalei River Watershed. This model requires input for the various sediment sources within a watershed, such as sheet and rill erosion, streambank and channel processes, and mass wasting. In an effort to understand the relative contribution from each of these sources, an assessment of the above components was attempted. Soil samples were collected from 22 sites on various geomorphic surfaces within the Hanalei River Watershed and near Koke e above Waimea Canyon (fig. 1). The concentration of ${ }^{137} \mathrm{Cs}$ in the samples can be used to obtain an indication of erosion sources and floodplain deposition within the watershed. The four sites near Koke`e were sampled to check ${ }^{137} \mathrm{Cs}$ levels at higher elevations and in differing precipitation zones than those within the Hanalei Watershed. The highest sampling elevation in the watershed was above a waterfall at approximately 3,800 ft. At this location a sample taken from a colluvial bench yielded a ${ }^{137} \mathrm{Cs}$ value of $175 \mathrm{~Bq} / \mathrm{kg}$. The highest measurement of ${ }^{137} \mathrm{Cs}$ was in a sample of a muck soil (histosol) on a terrace (elevation approximately 1,100 ft). This sample had ${ }^{137} \mathrm{Cs}$ value of $236 \mathrm{~Bq} / \mathrm{kg}$ at a depth of $38-52 \mathrm{~cm}$. Measurement of the samples for ${ }^{137}$ Cs content was performed by Dr. Jerry Ritchie, ARS, Beltsville, Maryland.

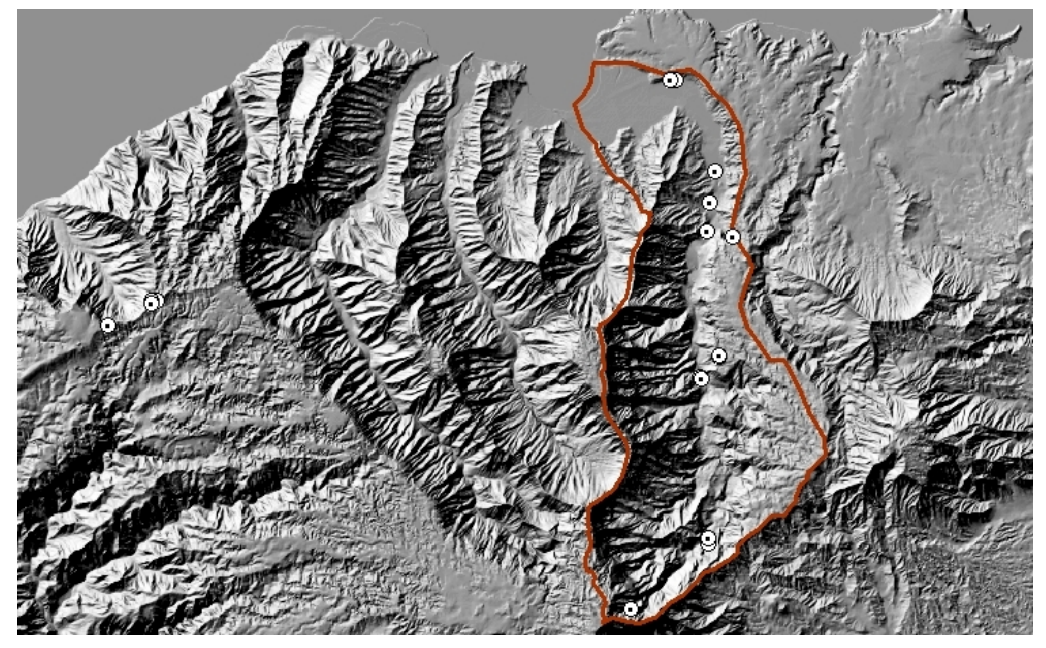

Figure 1. Location of sites sampled for Cesium-137.

\footnotetext{
${ }^{1}$ USDA Natural Resources Conservation Service, 101 SW Main St., Ste. 1300 Portland, OR 97204-3211
} 
Additionally, an assessment of streambank erosion along the Hanalei River was made primarily by observations of flight videos, as well as by accessing river segments by helicopter. A total of six helicopter trips were made by this author into the watershed, during which soil samples were collected, streambank erosion observations were made, and streambank recession rates were estimated. Additional observations were made of mass wasting occurrences on flights into and out of the various landing zones within the watershed. In the lower alluvial section of the watershed, segments of the streambanks were observed by kayaking or hiking to various locations, and through comparison of aerial imagery of different ages to attempt a change analysis. Streambank erosion and mass wasting are significant contributors to the overall sediment yield to Hanalei Bay. Erosion of streambanks in the alluvial lowland near Hanalei includes geotechnical failures and direct attack by streamflow. The avulsion near the USFWS Refuge boundary, in particular, has produced fine sediment that is readily transported to the bay.

Things to do

- Sampling potential sediment sources - additional sampling is needed to characterize the streambank sources of sediment. To draw conclusions on the proportion of sediment derived from surface erosion versus channel erosion, additional sampling is needed of the bed and bank materials for cesium content. Once the various sites are sampled and tested, an analysis can be performed using a mixing model such as the one described by Nagel and Ritchie to determine the relative contribution by the different sediment sources.

- Modeling of streambank erosion and channel processes-more data is needed to determine streambank recession rates at erosion sites along the mainstem and major tributaries. Data collection should include measurement of bed and bank materials for their physical properties, erosion resistance, etc.

- Mass wasting evaluation-mass wasting in the form of debris flows and slumps is a relatively common occurrence within the Hanalei River Watershed. Methods to predict timing, volume, particle tracking, and delivery of sediment from this source via modeling should be evaluated and developed. 


\title{
Water Quality Regulation in the Hanalei Bay Watershed
}

\author{
David Penn', Amy King ${ }^{2}$, Andrew Parker ${ }^{3}$, John Craig ${ }^{4}$, and Sen Bai ${ }^{3}$
}

Over the past ten years, water-quality measurements and observations from numerous points within the Hanalei watershed indicated actual and potential exceedances of State regulatory limits for turbidity, indicator bacteria, and nutrient concentrations in the water column. Riding on the coattails of EPA's Watershed Initiative Grant to the Hanalei Watershed Hui, the Hui and the State of Hawaii Department of Health (DOH) obtained additional support from EPA to have Tetra Tech, Inc. help us determine how to cap pollutant loadings (TMDLs) such that these regulatory concentration limits would not be exceeded.

We established two automated stormflow sampling stations (one freshwater, one estuarine) in the lower reaches of Hanalei River and obtained sediment and nutrient data from storm events on March 9 and March 16, 2006. We used these results and additional data from DOH, HWH, and USGS monitoring efforts to evaluate existing water-quality conditions, analyze watershed hydrology and pollution dynamics, and model the relationships between watershed characteristics, pollutant mass loading, and receiving water quality. The analysis included calculations of pollutant load capacities (based on regulatory concentration limits) for each stream and estuary, and allocations of these capacities to identified pollutant sources. These allocations provide guidance for implementing management measures that lead to load reductions.

The data confirmed exceedances of the regulatory limits throughout the watershed, except for freshwater segments of Waikoko Stream (no data) and Waipa and Waioli Streams (no bacterial indicator data, no nutrient exceedances). Total phosphorous and total nitrogen concentrations were strongly correlated to sediment concentrations. Concentrations of all pollutants generally increased from upstream to downstream, more obviously for nutrients than for sediment and indicator bacteria, with ammonia showing a distinctively steeper concentration gradient than other nutrients. Model results suggest that load reductions of 54 to $98 \%$ are required to prevent most sediment and nutrient exceedances, 21 to $99 \%$ for bacterial indicator exceedances.

\footnotetext{
${ }^{1}$ State of Hawaii Department of Health, Environmental Health Administration, Environmental Planning Office, 919 Ala Moana Blvd., Honolulu, HI 96814

${ }^{2}$ Tetra Tech, Inc., 508 West Main Street, Urbana, IL 61801

${ }^{3}$ Tetra Tech, Inc., 10306 Eaton Place, Ste. 340, Fairfax, VA 22030

${ }^{4}$ Tetra Tech, Inc., 1230 Columbia Street, Ste. 520, San Diego, CA 92101
} 


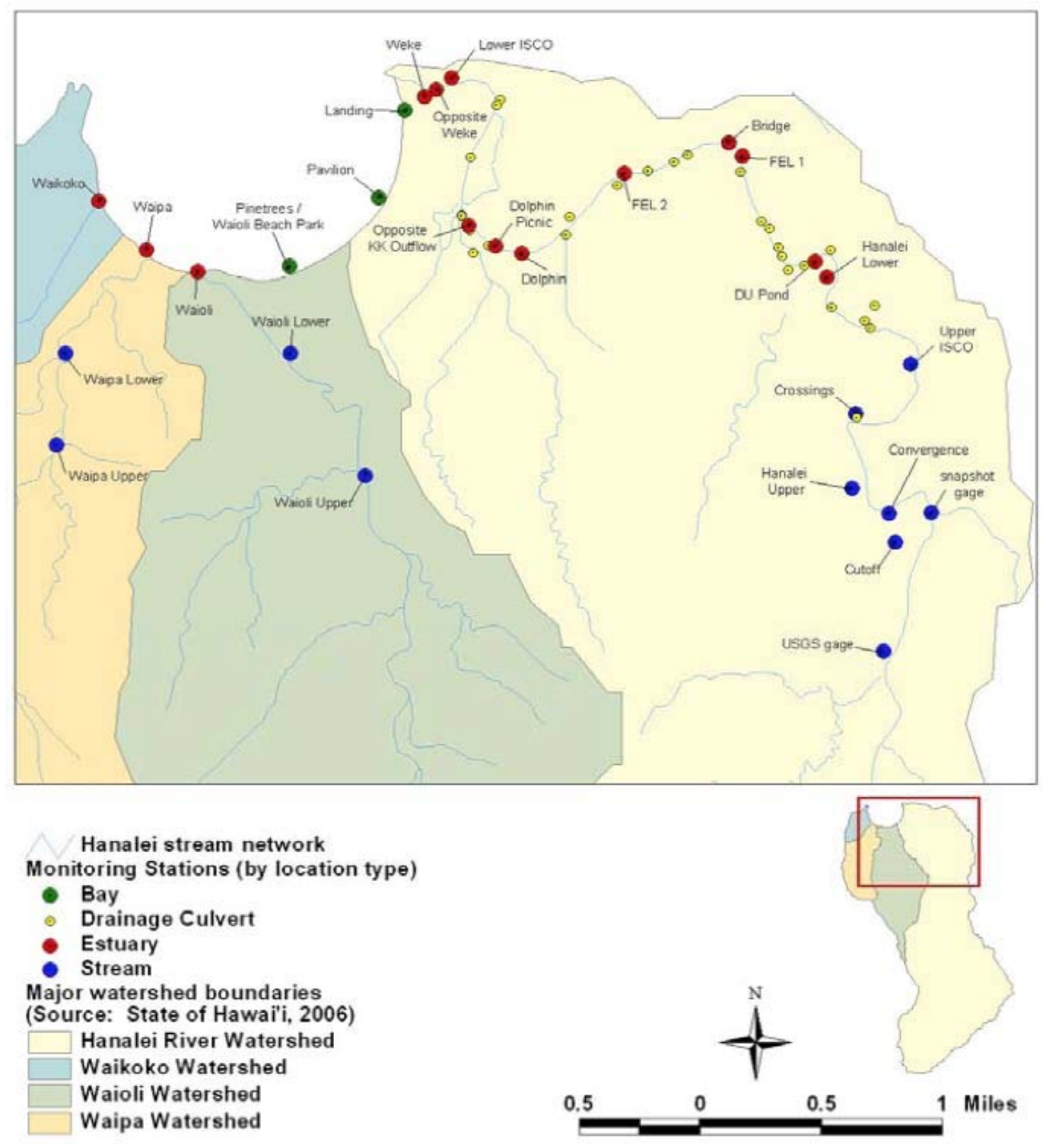

The modeling framework consists of a series of watershed models (based on the Loading Simulation Program in C++ [LSPC]) and a receiving water model (based on the Environmental Fluids Dynamic Code [EFDC]). The watershed models predict flow and pollutant loadings draining to Hanalei Bay, while the receiving water model simulates water circulation and pollutant transport in the estuary/bay system.

LSPC model output also partitions pollutant loading among land cover types. Initial results suggest that the main pollutant sources are open areas (scrub/shrub and evergreen forest land cover types), runoff from agriculture, and waterbird impoundments. Among these, the bulk of the bacterial source areas appear to include wildlands and wetlands in the larger watersheds (Hanalei, Waioli, Waipa) and cultivated lands in Waikoko. Management strategies that address TSS are likely to also reduce total $\mathrm{N}$ and 
total P, and the main source areas for sediment appear to be unmanaged lands in the larger watersheds. Cultivated lands in Waikoko are suggested as a major contributor of total $\mathrm{N}$ and total $\mathrm{P}$, and cultivated lands throughout the watershed seem to represent the main source of ammonia and nitrate nitrogen.

Relative Loadings by Land Cover for the Hanalei Bay Watershed

\begin{tabular}{|l|c|c|c|c|c|c|c|}
\hline \multirow{2}{*}{$\begin{array}{l}\text { Land cover } \\
\text { Bare Land }\end{array}$} & $\begin{array}{c}\text { Percent of total } \\
\text { area }\end{array}$ & \multicolumn{6}{c|}{ Percent of total load } \\
\cline { 3 - 8 } & $0.1 \%$ & $0.01 \%$ & $0.1 \%$ & $0.02 \%$ & $0.04 \%$ & $0.04 \%$ & $0.05 \%$ \\
\hline Cultivated Land & $2.6 \%$ & $2 \%$ & $2 \%$ & $64 \%$ & $20 \%$ & $6 \%$ & $8 \%$ \\
\hline Evergreen Forest & $25.2 \%$ & $27 \%$ & $16 \%$ & $6 \%$ & $14 \%$ & $17 \%$ & $17 \%$ \\
\hline Grassland & $3.5 \%$ & $0.4 \%$ & $2 \%$ & $1 \%$ & $2 \%$ & $1 \%$ & $2 \%$ \\
\hline $\begin{array}{l}\text { High Intensity } \\
\text { Developed }\end{array}$ & $0.02 \%$ & $0.1 \%$ & $0.1 \%$ & $0.01 \%$ & $0.1 \%$ & $0.003 \%$ & $0.003 \%$ \\
\hline $\begin{array}{l}\text { Low Intensity } \\
\text { Developed }\end{array}$ & $0.8 \%$ & $0.4 \%$ & $1 \%$ & $0.2 \%$ & $1 \%$ & $0.2 \%$ & $0.2 \%$ \\
\hline Palustrine Emergent & $0.6 \%$ & $7 \%$ & $2 \%$ & $4 \%$ & $7 \%$ & $3 \%$ & $2 \%$ \\
\hline $\begin{array}{l}\text { Palustrine } \\
\text { Forest/Scrub }\end{array}$ & $1.7 \%$ & $0.3 \%$ & $2 \%$ & $1 \%$ & $1 \%$ & $2 \%$ & $2 \%$ \\
\hline Scrub/Shrub & $64.5 \%$ & $63 \%$ & $75 \%$ & $24 \%$ & $55 \%$ & $70 \%$ & $69 \%$ \\
\hline Water & $0.9 \%$ & $0 \%$ & $0.2 \%$ & $0.1 \%$ & $0.3 \%$ & $0.3 \%$ & $0.4 \%$ \\
\hline
\end{tabular}

The watershed and receiving water models provide a framework for quantifying sediment, bacteria, and nutrient loads spatially and temporally throughout the watershed. They can be used to identify source "hot spots," evaluate the relative impact of surface and groundwater contributions, and identify monitoring data gaps. Additionally, "whatif" scenarios may be represented within the framework to predict the impact of water pollution controls on water quality conditions throughout the stream systems.

Spatial and temporal variability of water quality remains poorly defined for many combinations of flow regime, location, and pollutant. In addition to actively implementing watershed load reductions, future DOH interests include:

1. establishing TMDLs and load allocations for the marine waters (Hanalei embayment and open coastal waters) and

2. developing and executing a comprehensive Hanalei Bay Watershed water quality monitoring strategy that provides the information needed to improve our understanding of water quality dynamics and to support $\mathrm{DOH}$ decisions about:

a. public safety and health (recreational activities and subsistence fishing)

b. attainment of designated uses and water-quality criteria (waterbody assessment), and

c. assigning management priorities and selecting management measures (polluted runoff control) 


\section{Magnetic Study of Sediment in Hanalei Bay and the Hanalei River}

\section{Watershed: Contribution to Understanding Sources and Transport of}

\section{Terrigenous Sediment}

Richard Reynolds ${ }^{1}$, Michael Bothner ${ }^{2}$, Carl Berg ${ }^{3}$, Amy Draut ${ }^{4}$, and Harland Goldstein ${ }^{1}$

Investigations of magnetic properties of sediments in the reef-watershed system of the Hanalei Bay and Hanalei River, Kaua i, Hawai i, complement studies of composition, texture, and radioisotopes $\left({ }^{7} \mathrm{Be}\right.$ and $\left.{ }^{137} \mathrm{Cs}\right)$ to determine patterns of sedimentation in the Bay (Draut and others, 2006; and this vol., p. 22). These combined studies also provide information about (a) sources of sediment; (b) aspects of sediment transport and deposition in the bay-watershed system, such as mineral sorting; and perhaps (c) stability of land surfaces that yield flood sediment. Samples have been selected from cores, sediment traps, bottom and suspended river sediment, and upland sites. The upland sites represent several different landscape settings, including taro fields, steep banks of the Hanalei River, mud in minor drainages, poorly drained forest floor, and flood sediment that was trapped by a grassy surface between the edge of the river and taro fields.

Magnetic iron oxide minerals in the bay sediments originate in the watershed. Magnetic properties of bay sediments record detrital input from the watershed and may reflect sources and landscape settings of upland sediment. Magnetic mineral types and magnetic grain sizes (domain states) vary among different volcanic rocks according to magmatic composition and cooling history (Reynolds and others, 1990; Rosenbaum and others, 1991; 1994), variations that are commonly inherited in derived soils and volcanogenic sediments. Subsequent changes in magnetic properties result from weathering of soil and sediment (e.g., oxidation of magnetite to hematite; development of pedogenic Fe oxides) depending on geomorphic, hydrologic, and microbial setting.

In the cores, magnetite abundance, as determined by magnetic susceptibility and isothermal remanent magnetization (IRM), is negatively correlated with carbonate abundance. Magnetite abundance thus provides a measure of input of terrigenous sediment to the Bay. Moreover, magnetic grain-size parameters reflect bulk-sediment particle size, with increasing content of single-domain magnetite correlating with increasing content of fines (silt and clay).

\footnotetext{
${ }^{1}$ USGS, PO Box 25046, Denver Federal Center, MS 980, Denver CO 80225

${ }^{2}$ USGS Woods Hole Science Center, 384 Woods Hole Road, Woods Hole, MA 02543

${ }^{3}$ Hanalei Watershed Hui, PO Box 1285, Hanalei, HI 96714

${ }^{4}$ USGS Pacific Science Center, 400 Natural Bridges Dr., Santa Cruz, CA 95060
} 
Broad variations in concentration-independent properties (magnetic grain size; relative magnetite-hematite abundance) with depth in bay sediments at sites A, C, and I (early and late summer, 2006) indicate many sources of upland sediment. Nevertheless, flood deposits (defined here as having IRM $>0.08 \mathrm{Am}^{2} \mathrm{~kg}^{-1}$ ) show much less variation in these properties compared with non-flood deposits and with the sampled upland deposits. This observation implies (1) an upland source or sources for the flood deposits of winter and summer 2006 from one or a few distinct landscape settings, or (2) strong mineral sorting of sediment from multiple sources during transport in floodwaters that produced nearly uniform iron-oxide content in sediment deposited in and near the Black Hole.

We found no exact match among magnetic properties when comparing flood deposits in cores with upland samples. In these comparisons, closest similarities are found with sediment in taro fields (five samples) and in banks of the lower river (two samples). Mineral sorting during transport in the lower reaches of the river during floods might explain the observed small discrepancies in magnetic grain-size parameters, assuming that our samples are representative of these landscape settings.

The magnetic properties of flood deposits in the cores and in sediment trapped near the river mouth are closely similar in absolute abundance of magnetite and hematite, in relative amounts of these minerals, and in magnetic grain size. Suspended sediment in the river (one sample) also yields closely similar results. Sediments in other traps deployed in the bay contain lower amounts of magnetite and hematite perhaps caused by sorting out of these highdensity minerals with distance from the river mouth.

Flood deposits in the cores (again, on the basis of IRM>0.08 $\mathrm{Am}^{2} \mathrm{~kg}^{-1}$ ) have much higher content of ${ }^{137} \mathrm{Cs}$ than non-flood samples. This observation indicates that recent floods have tapped, to strong extent, sediment that was exposed to the atmosphere at some point about 40-60 years ago. The linkage between high ${ }^{137} \mathrm{Cs}$ and flood deposits appears to be controlled by particle size: ${ }^{137} \mathrm{Cs}$ is relatively abundant in fine-grained core sediment, as it appears to be also in fine-grained watershed deposits, such as taro fields and flood sediment derived from the fields. Similar relations are found for ${ }^{7} \mathrm{Be}$ in these deposits. Dilution of the isotopic signals by high carbonate abundance should also be considered as an explanation for this linkage.

Taken together, magnetic and isotopic data strongly suggest that a significant component of recent flood deposits in the Bay have been derived from exposures in the lower watershed, much of it possibly from taro fields. Significant contribution from riverbanks seems precluded by ${ }^{137} \mathrm{Cs}$ data. We have not obtained samples to evaluate directly any possible contributions from intermediate and high elevations $(>300 \mathrm{~m})$ that would include landslide debris and large areas disturbed by feral pigs. 


\section{Background References}

Draut, A.E., Field, M.E., Bothner, M.E., Logan, J.B., Casso, M.A., Baldwin, S.M., Reynolds, R.L., and Storlazzi, C.D., 2006, Seasonal flood deposits in Hanalei Bay, Kaua i, Hawai i; Implications of fluvial sedimentation for coral-reef ecosystems: EOS, Transactions of the American Geophysical Union, 87(52), Fall Meeting Supplement, Abstract OS23A-1616.

Reynolds, R.L., Rosenbaum, J.G., Hudson, M.R., and Fishman, N.S., 1990, Rock magnetism, the distribution of magnetic minerals in the Earth's crust, and aeromagnetic anomalies; in Hanna, W.F., ed., Proceedings of a Workshop in Geologic Applications of Modern Aeromagnetic Surveys: U.S. Geological Survey Bulletin 1924, p. 24-45.

Rosenbaum, J.G., Reynolds, R.L., and Schlinger, C.M., 1991, Effects of cooling on oxide mineralogy and magnetic properties near margins of volcanic bodies: EOS, American Geophysical Union Transactions, v. 72, p. 138.

Rosenbaum, J.G., Reynolds, R.L., and Hildenbrand, T., 1994, Insight into the structure of the East Rift Zone of Kilauea, Hawai i, from a rock magnetic study of drill core: VIIth International Drilling Symposium Proceedings, p. 142-145. 


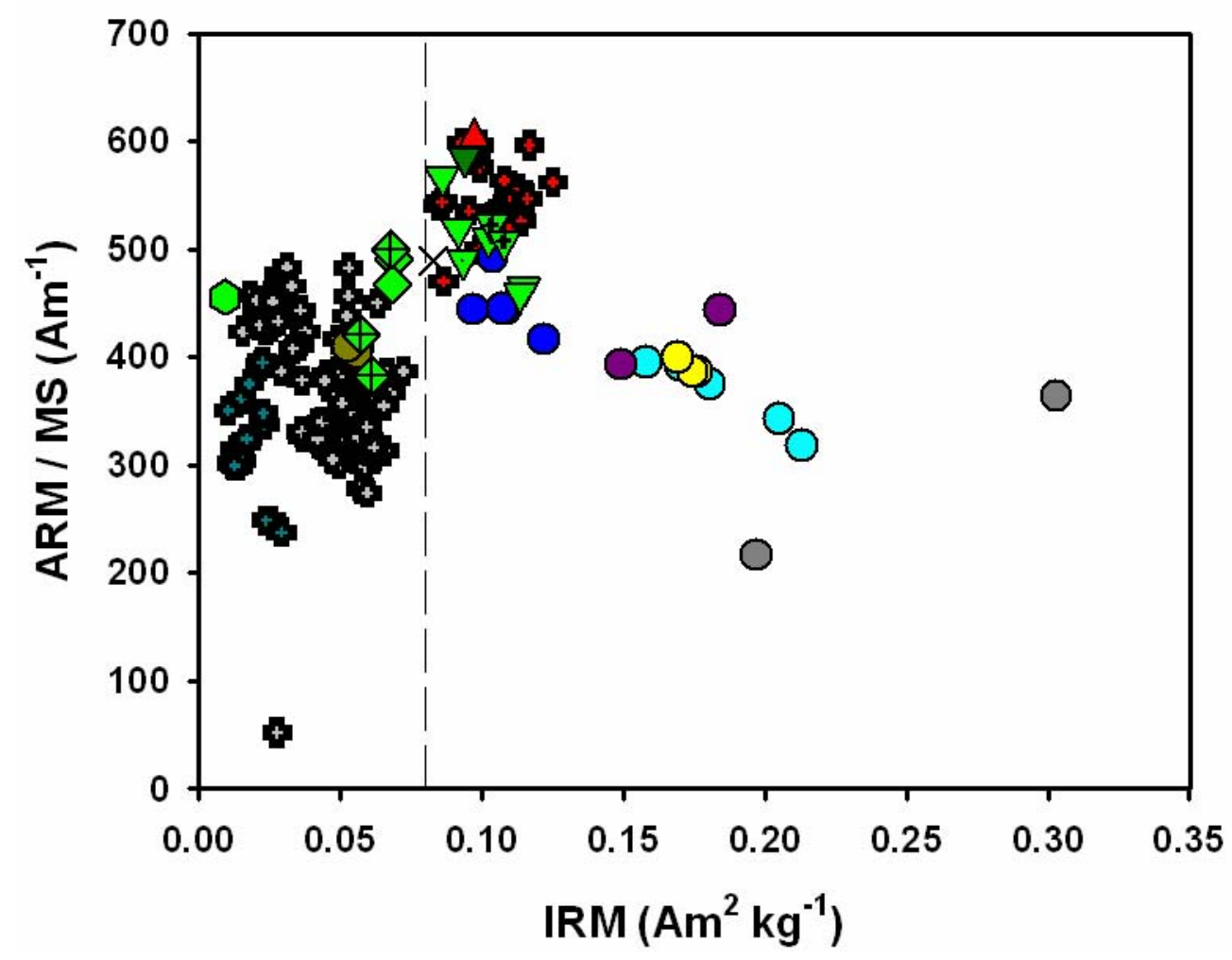

Figure 1. Magnetic properties of sediment from cores, traps, river (sediment in suspension), and upland sites. Plot of isothermal remanent magnetization (IRM, a measure of magnetite abundance) vs. the ratio of anhysteretic remanent magnetization to magnetic susceptibility (ARM/MS, a measure of magnetic grain size, with higher ARM/MS indicating smaller magnetic grain size having relatively more single-domain magnetite). Symbols are as follows: crosses are core samples; circles are samples from upland sites; inverted triangles are sediment from traps in the bay near the mouth of the Hanalei River; diamonds and hexagon are sediment from other traps in the bay; $x$ is the average of all trap sediments; red triangle is the suspended sediment. Flood deposits in the bay are defined here as core sediment with IRM>0.08 $\mathrm{Am}^{2} \mathrm{~kg}^{-1}$ and are shown in red crosses to the right of the vertical dashed line. Colors of the upland sites (circles): dark blue, taro fields; yellow, grassy surface near the fields; olive, forest floor; light blue, river banks and river mud near the USGS gauging station on the Hanalei River; purple, banks of the lower river; gray, mud and soil from nearby sites along the power-line road at about 300-m elevation, east of the Hanalei River. 


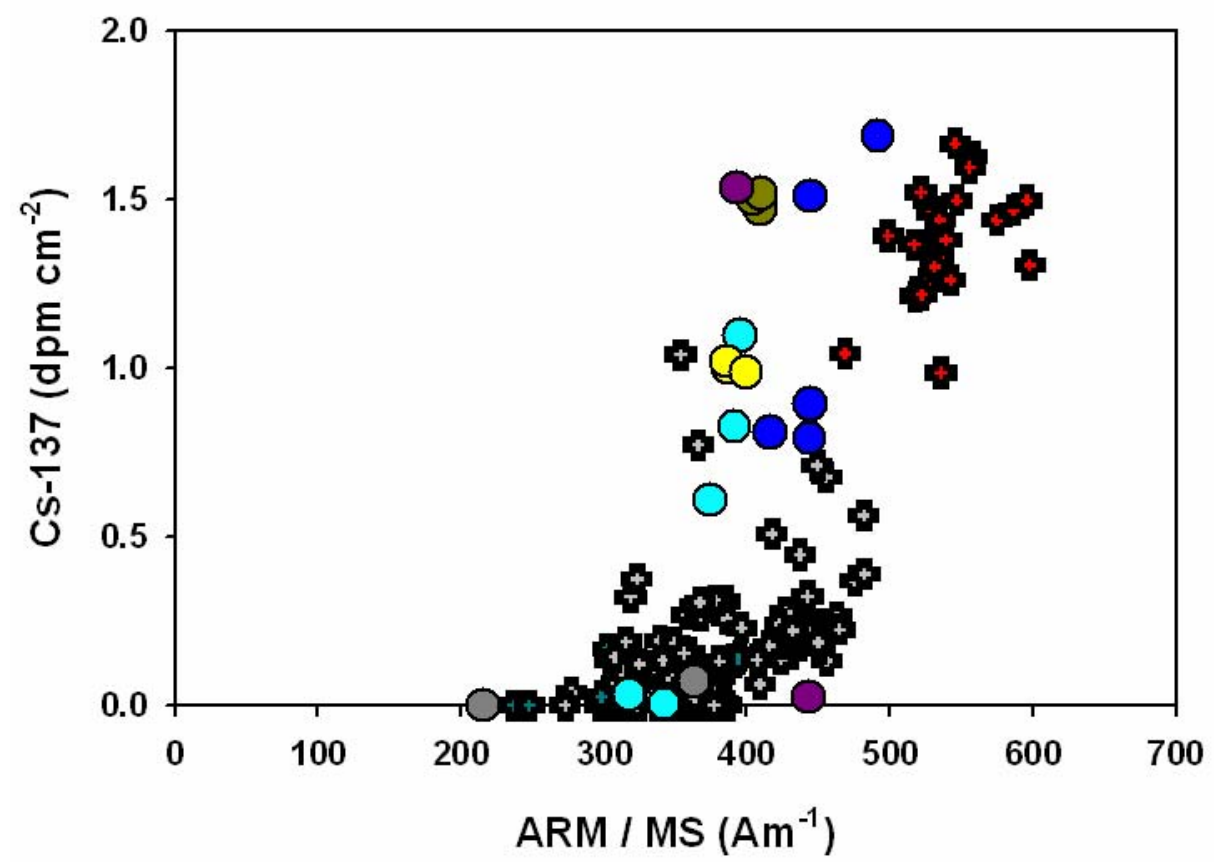

Figure 2. Magnetic grain size and ${ }^{137}$ cesium values for sediment from cores and upland sites. Plot of ${ }^{137}$ cesium the ratio of anhysteretic remanent magnetization to magnetic susceptibility (ARM/MS, a measure of magnetic grain size, with higher ARM/MS indicating smaller magnetic grain size having relatively more single-domain magnetite). Symbols as above. 


\section{Geomorphic Assessment of the Hanalei Stream Network Including Preliminary}

\section{Hydraulic Geometry Analysis Results}

\section{Matt Rosener'}

The Hanalei Watershed Study was initiated to identify patterns of erosion and sedimentation within the Hanalei River Basin and to develop recommendations for management practices to regulate sediment yields from the Hanalei Bay watersheds. An investigation into the fluvial processes in the Hanalei stream systems is being performed to support the watershed study, focusing on these processes as they relate to erosion, transport, and deposition of sediments in the stream channel network.

Stream channels within the valley range from ephemeral headwater streams generally located near the watershed divide, to short first- and second-order tributary streams that connect the headwater reaches to the valley bottom, to the fourth-order mainstem Hanalei River channel that ultimately drains through a 3.5-mile estuary reach to Hanalei Bay. Stream-channel morphology is strongly influenced here by valley form, channel gradient, and sediment size (or the presence of bedrock). In parts of the Hanalei Valley, particularly along the lower reaches of the mainstem river, riparian vegetation (i.e. hau) is also a significant control on channel form.

Stream channels are generally confined by steep-sided, V-shaped valley sections throughout much of the watershed, except the lower valley where the mainstem river breaks out of the confined canyon into a broad floodplain. Bed sediments in much of the drainage network are dominated by the cobble - boulder size fractions. Field observations suggest that relatively little deposition of fine sediment occurs in the

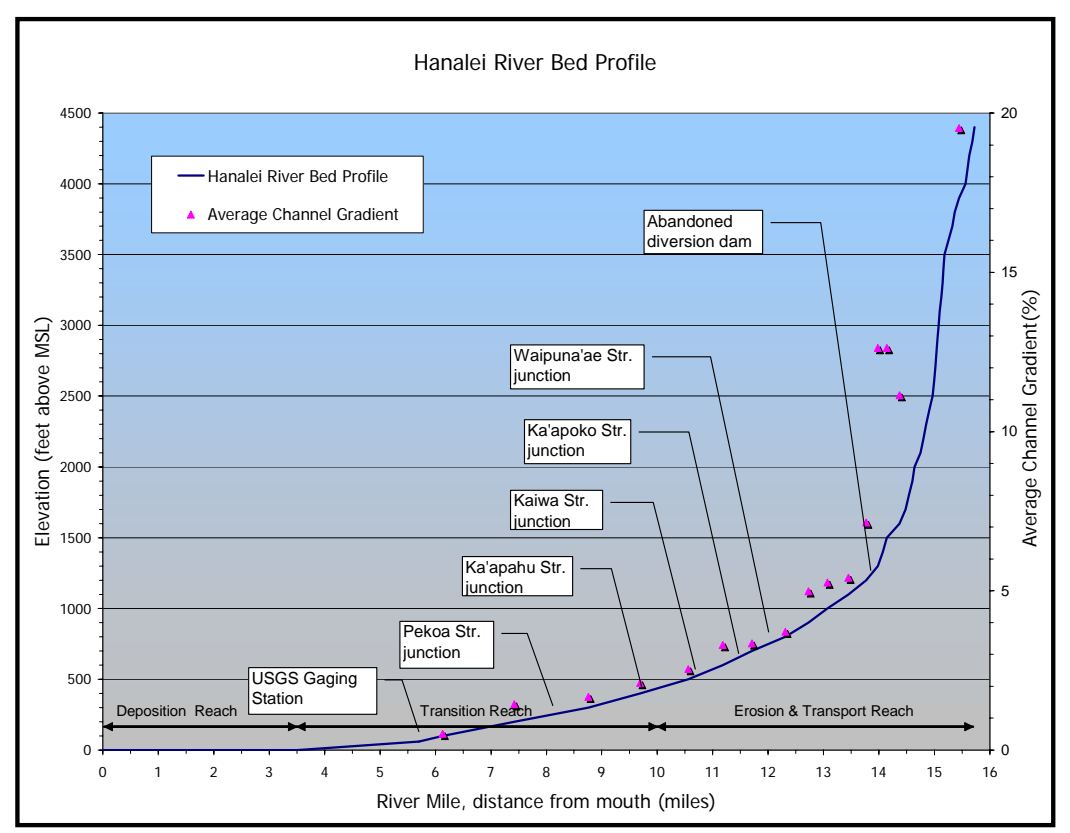
steep channel reaches that constitute much of the drainage network, although the channel bed may act as a significant reservoir for fines. Because the streambeds are generally heavily armored by cobble to boulder-sized rock, it is likely that this reservoir is only tapped during episodic, peak flow events. The riverbed in the lower valley grades to gravel, sand, and eventually silt/clay substrate, fitting the classic pattern of downstream fining. Channel gradients span the full range from level (along the entire 3.5-mile estuary reach) to vertical (for ephemeral streams on the valley walls).

${ }^{1}$ Hanalei Watershed Hui, PO Box 1285, Hanalei, HI 96714 
During several fly-in field expeditions in various parts of the Hanalei Valley, stream surveys were performed to collect information about channel geometry, bed slope, bed/bank stability, and roughness elements (both vegetation and bedforms). These factors are all known to significantly affect local channel hydraulics and sediment transport capacity. An attempt was made to establish hydraulic-geometry relationships for the stream network, using drainage area as a surrogate for bankfull discharge. For this analysis a total of 25 cross-section surveys have been performed to date, 7 of these along the mainstem Hanalei River and the other 18 on tributary streams, generally just upstream of their confluence with the mainstem. Discharge measurements were made at many of the survey sites and these were used to backcalculate hydraulic roughness values for channel segments. These data may be used for routing routines in hydrologic models to simulate water and sediment movement through the stream network.

The results of the hydraulic geometry analysis generally indicate a strong correlation $\left(\mathrm{R}^{2}=0.91\right)$ between channel bankfull width and contributing drainage area and a weak correlation $\left(\mathrm{R}^{2}=0.40\right)$ between bankfull depth and drainage area for both the mainstem river and the tributary streams. This result was expected due to the dominance of step-pool channel form in a large percentage of the drainage network.

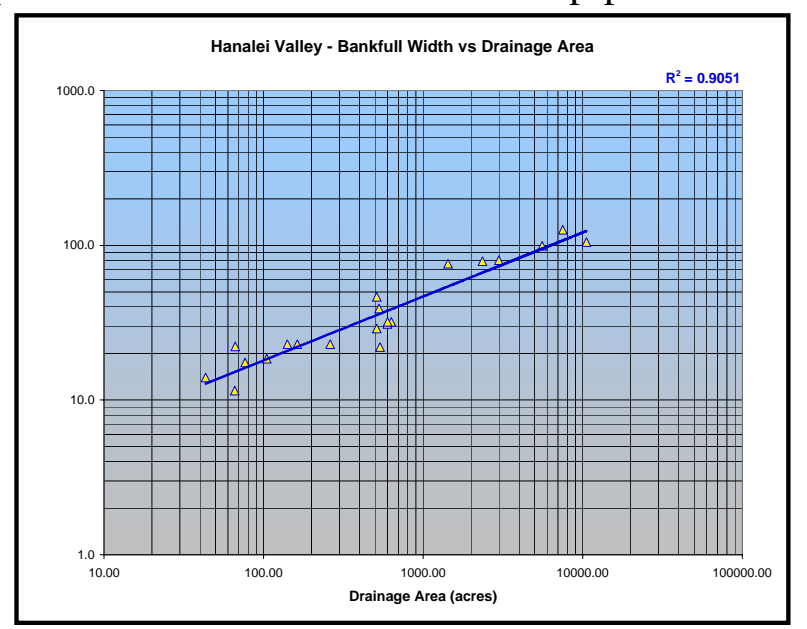

these drops due to the inevitable turbulence that develops in these channel reaches. It may be the case that strong relationships between bankfull depth and discharge (or drainage area) could be developed for lower-gradient stream reaches where pool-riffle morphology is more dominant (as opposed to step-pool morphology), but the data collected for this analysis were not sufficient to test this hypothesis.

Also of note is the presence of multiple terraces, or abandoned floodplain surfaces, along much of

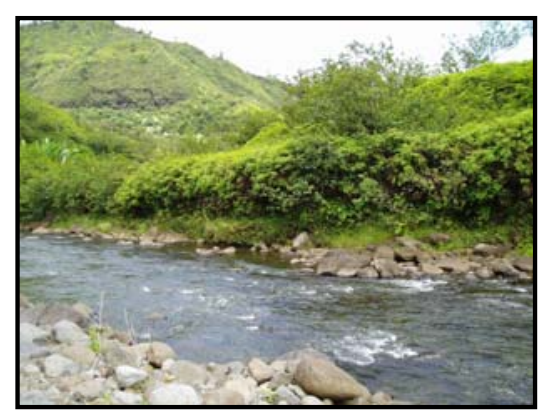
the mainstem Hanalei River. These terraces are found consistently at heights of 10-25 feet above the present stream grade, providing evidence of significant stream downcutting in the past. While channel incision is not considered to be a significant erosion mechanism in the valley at the present time when compared to hillslope erosion (sheet and rill, gully, mass wasting) or streambank erosion, it should be noted that this mechanism has been responsible for the evacuation of large volumes of sediment from the valley in the past. No data is currently available to attempt to date these past periods of major channel incision. 


\title{
Applying the Science: Taking Steps to Improve Water Quality and Coral Reef
}

\section{Communities}

\author{
Audrey Shileikis', Wendy Wiltse', Hudson Slay', Dave Penn², and Katherine Chaston ${ }^{3}$
}

The Hanalei Watershed Hui and its many partners have invested significant time and resources to understand the dynamics and the impact of pollutants on the coral reefs, estuary, and streams from the ridges to the reef. This workshop is a great opportunity to share what we have learned and to identify what we need to do next towards achieving our mutual goal to improve water quality and coral reef ecosystem function and health in the Hanalei Bay Watershed.

The U.S. Environmental Protection Agency, the Hawaii Department of Health, and other partner agencies represented on Hawai i's Local Action Strategy (LAS) to Address Land-Based Pollution Threats to Coral Reefs have a strong interest in taking specific steps that will address land-based sources of pollution to improve water quality and the health of the coral reef ecosystem. EPA and DOH are working to focus appropriate financial, programmatic, and technical resources on a limited number of watersheds in the interest of achieving and documenting water quality improvements.

The Hanalei Watershed Hui and its partners have been working since the late 1990's to better understand and address numerous issues affecting the health and the people of the watershed. The Hanalei Watershed was designated as an American Heritage River in 1998, named a priority watershed for the Land-Based Pollution LAS in 2003, and received a targeted Watershed Grant from EPA in 2005. Many other federal, state, local and non-profit groups, as well as the community have invested significantly in the watershed. With the draft total maximum daily load (TMDL) for Hanalei out for public review and the 2-day Hanalei Watershed workshop providing a forum to exchange information concerning the monitoring, assessment, and implementation activities it is a critical time to consider and evaluate management options for improving water quality. How will this information be used to support decisions intended to improve water quality? Which management practices should be implemented and where? What additional assessments are necessary?

The TMDL Implementation Matrix (below) provides a summary of pollutants and waterbodies, potential sources, locations, recommendations and potential implementers, based on the draft TMDL. Primary pollutants of concern include nutrient, pathogens, and sediment levels that have affected water quality, coral reefs, and the natural ecosystem. Waters in the Hanalei Bay watershed are impaired and on the States' Section 303(d) of Impaired Waters for Enterococcus (fecal indicator bacteria) and turbidity.

\footnotetext{
${ }^{1}$ U.S. Environmental Protection Agency, PO Box 50003, Honolulu, HI 96850

${ }^{2}$ State of Hawaii, Department of Health, Environmental Health Administration, Environmental Planning Office, 919 Ala Moana Blvd., Honolulu, HI 96814

${ }^{3}$ Hawai' i's Local Action Strategy to Address Land-Based Pollution Threats to Coral Reefs, University of Hawai i at Manoa, Dept. of Natural Resources and Environmental Management, 1910 East-West Rd., Honolulu, HI 96822
} 
There is also data indicating that the level of nutrients may not meet water quality standards, but the waters are not currently on the Section 303(d) list. The draft TMDL calls for a 90-99 \% reduction in current loads of sediment, Enterococcus, and nutrients.

Goal: To improve water quality and coral reef ecosystem function and health in the Hanalei Bay Watershed by 2012.

\section{Expected Outcomes for the Hanalei watershed:}

- Reduction of pollutant loads and improvement in baseline water quality (as established in 2002) by 2012

- Partial restoration of water quality, defined by a delisting of one pollutant in at least one waterbody in the watershed by 2012

\section{What is it going to take to reduce pollutant loads and achieve water quality improvements?}

- Where in the watershed (or on what sources) should we focus management efforts?

- Which management practices have worked and not worked in reducing loads?

- How do we assess effectiveness of management practices?

- How much implementation is needed to see results?

- What kind of support is needed from the LAS, agencies and scientists to sustain the overall Hanalei watershed effort? 
Example - TMDL Implementation Matrix

\begin{tabular}{|c|c|c|c|c|}
\hline POLLUTANT and Waterbody & POTENTIAL SOURCE & LOCATION & POTENTIAL MGMT ACTIVITIES & "POTENTIAL IMPLEMENTERS \\
\hline $\begin{array}{l}\text { TURBIDITY (SEDIMENT) } \\
\text { Hanalei Stream/Estuary; } \\
\text { Waioli, Waipa, Waikoko } \\
\text { Estuaries }\end{array}$ & $\begin{array}{l}\text { Alteration of forested landscape } \\
\text { by feral livestock, alien tree and } \\
\text { plant species } \\
\text { Streambank erosion } \\
\text { Landslides } \\
\text { Cultivated land/taro lo'i }\end{array}$ & $\begin{array}{l}\text { Forested portions of } \\
\text { watershed }\end{array}$ & $\begin{array}{l}\text { Fishpond/stream restoration } \\
\text { Trail restoration/road management } \\
\text { Sedimentation basins } \\
\text { Determine natural vs. anthropogenic } \\
\text { sediment contributions }\end{array}$ & $\begin{array}{l}\text { Kaua`i County, Hanalei Watershed Hui, DLNR } \\
\text { (DOFAW), USFWS, Watershed Partnership, } \\
\text { DOH, taro farmers, Waipa Foundation, } \\
\text { Kamehameha Schools }\end{array}$ \\
\hline $\begin{array}{l}\text { ENTEROCOCCUS } \\
\text { Hanalei Estuary }\end{array}$ & $\begin{array}{l}\text { Individual wastewater } \\
\text { systems } \\
\text { Feral and domestic animals } \\
\text { Soil background }\end{array}$ & $\begin{array}{l}\text { Wildlands and wetlands in the } \\
\text { larger watersheds (Hanalei, } \\
\text { Waioli, Waipa) and cultivated } \\
\text { lands in Waikoko }\end{array}$ & $\begin{array}{l}\text { Cesspool closure/upgrade } \\
\text { Septic system installation/upgrade } \\
\text { Centralized wastewater treatment } \\
\text { system } \\
\text { Ungulate fencing/management } \\
\end{array}$ & $\begin{array}{l}\text { Kaua`i County, Hanalei Watershed Hui, DLNR } \\
\text { (DOFAW), USFWS, Watershed Partnership, } \\
\text { DOH, taro farmers, Waipa Foundation, } \\
\text { Kamehameha Schools }\end{array}$ \\
\hline $\begin{array}{l}\text { NUTRIENTS } \\
\text { Hanalei, Waioli, Waipa, } \\
\text { Waikoko stream/estuary }\end{array}$ & $\begin{array}{l}\text { Individual wastewater systems } \\
\text { Agriculture (fertilizers) } \\
\text { Residential use of fertilizer? } \\
\text { Pet waste? } \\
\text { Watershed background }\end{array}$ & Cultivated lands & $\begin{array}{l}\text { Cesspool closure/upgrade } \\
\text { Septic system installation/upgrade } \\
\text { Centralized wastewater treatment } \\
\text { system } \\
\text { Education (pet waste, residential } \\
\text { fertilizer, etc) } \\
\text { Sediment management } \\
\end{array}$ & $\begin{array}{l}\text { Kaua`i County, Hanalei Watershed Hui, DLNR } \\
\text { (DOFAW), USFWS, Watershed Partnership, } \\
\text { DOH, taro farmers, Waipa Foundation, } \\
\text { Kamehameha Schools }\end{array}$ \\
\hline
\end{tabular}




\section{Summary of the 2006 Update to the Soil Survey for Hanalei Watershed}

Chris Smith ${ }^{1}$ and Katina Hanson ${ }^{1}$

\section{Soil Mapping}

The focus of this study was to assess soil-mapping deficiencies and provide greater soil survey details for the adaptation of the AnnAGNPS Model in Hawaiian watersheds. The most recent published soil survey of the island of Kaua i (Foote, et al 1972) was generally mapped at "High and Medium Intensity" for cultivated agricultural lands, lower intensity for grazing lands and "Reconnaissance" levels for mountainous terrain. Later efforts (1970s - 1990s) populated the soils database with estimated soil properties. This 2006 study included field visits to many locations, described the steep mountainous lands in greater detail and assigned soil properties, including RUSLE K factors, T factors and hydrologic soil groups (HSG) to improve output accuracy of the AnnAgNPS model.

Generally, the original mapping was accurate in the valley bottoms, lower watershed hills, and on the peneplain remnant known as "power line road". The current effort has shown that much of what was mapped as Rough Broken Land (rRR) and Rough Mountainous Land (rRT) can be defined into distinct soil series and that each map unit contains more than one major component. The drawing below provides a cross-sectional representation of the changes to the soil mapping.

By defining the midslope areas to a greater degree, assessment of erosion source potential as well as potential for productivity and reforestation will be improved. Nearly all of the steeplands in Hawai $i$ can be mapped in greater detail than was done in the original surveys. This study can serve as a pilot project for future mapping in this humid steep setting and similar settings on other islands.

\footnotetext{
${ }^{1}$ USDA Natural Resources Conservation Service, PO Box 50004, Honolulu, HI 96850-0050
} 
* Tentative Classifications

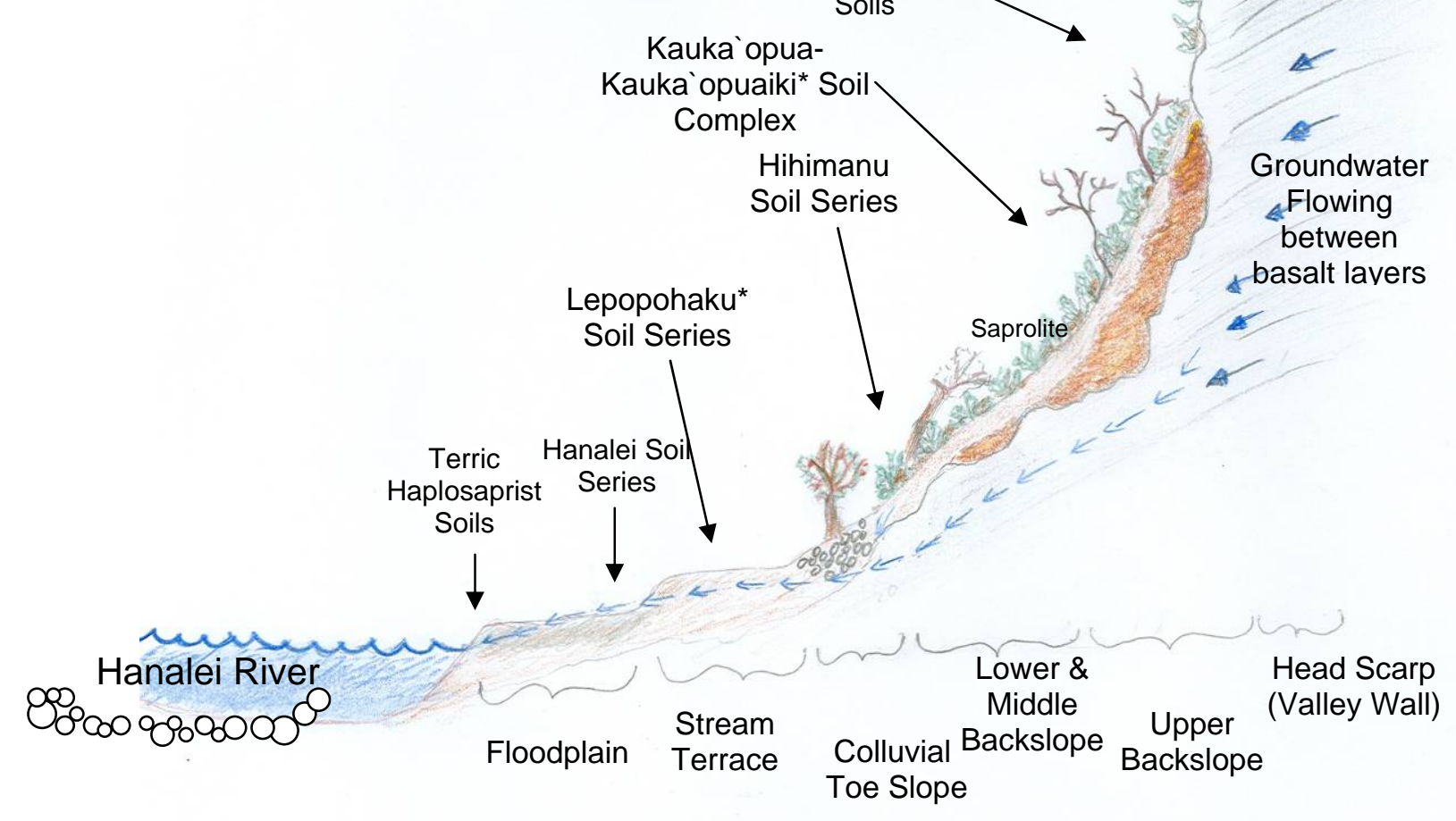

Figure 1. Conceptual cross-section drawing of Hanalei Watershed soils. Notes: Ko'olau soils not shown but found along Powerline Road and in the Waialeale area; Kauka'opuaKauka opuaiki Soil Complex mainly on secondary ridges and backslopes not receiving colluvium.

\section{Pig Damage and Landslides}

Much has been learned about effects of pigs and landslides in these areas albeit in a semi-quantitative way. It is the consensus of the field study group that severe control of the pig population is the one key undertaking needed in order to restore watershed health.

A few examples of narrow shoot-debris landslides of varying length (3 to 10 meters wide) were observed. They appeared to be a combination of live uluhe fern, undecomposed to decomposed uluhe litter and a thin soil and saprolite component associated with the uluhe rooting zone (estimated from 5 to $25 \mathrm{~cm}$ ). Revegetation of the slides appears to be visibly noticeable within six months and, after one year, the slide scar is almost completely revegetated although careful observation in the field or under stereo detect the scar.

Pig damage by trails or rooting is greatest in steep upland soils, averaging about $50 \%$ of the surface area. The percentage seems to be less in the lower watershed but few 
observations were made there. Among other effects of pig activity, ground cover is removed exposing the soil surface to splash detachment of soil particles and microaggregates. This process increases the RUSLE K factor and changes the Hydrologic soil group approximately two groups (such as B to D). The lack of aeration and ponding of water also creates reducing conditions, which is exacerbated by manure additions, rendering the site optimal for anaerobic microbe proliferation. The trails are compacted but appear to be less anaerobic and serve as a lacework of channels for overland flow. 


\title{
In Situ Measurements of Coastal Circulation and Sediment Dynamics in
}

\section{Hanalei Bay, Kaua i}

\author{
Curt Storlazzi', Kathy Presto', Josh Logan', and Mike Field'
}

Oceanographic measurements were made in Hanalei Bay, Kaua i, by the U.S. Geological Survey (USGS) Coastal and Marine Geology Program's Coral Reef Project during the summers of 2005 and 2006. The studies were designed to better understand coastal circulation and particulate dynamics in the bay during summer flood events. A larger goal was to better understand the transport mechanisms of sediment, larvae, pollutants and other particles in an embayment that hosts a nearshore coral reef ecosystem adjacent to a major river drainage. A series of bottom-mounted instrument packages were deployed in water depths of $10 \mathrm{~m}$ or less to collect long-term, high-resolution measurements of waves, currents, water levels, temperature, salinity and turbidity (fig. 1). These data were supplemented with a series of vertical instrument casts to characterize the vertical and spatial variability in water-column properties within the bay.

The water in Hanalei Bay is generally more saline and cooler farther offshore and with increasing depth (fig. 2). These general trends, however, are greatly influenced by the presence of freshwater either from river/stream discharge or groundwater effluence; lower salinities and higher turbidities were observed closer to shore, especially near the mouths of the Hanalei River and the Waipa and Waioli Streams. Flow was relatively weak and circulation was sluggish in Hanalei Bay during both summer study periods. Currents were generally oriented parallel to shore but varied vertically: the direction of near-surface flows was often the opposite to that of near-bed flows, causing vertical velocity shear. Net near-surface flow was into the eastern portion of the bay and out of the western portion of the bay; net near-bed flows had an opposite pattern. Most of the daily variability in current speed and direction at the study sites is due to the influence of tides. As the tide rises (floods), tidal currents close to the surface along the "Wall" off the Hanalei River's mouth flow to the southeast and are greater than those observed when the tide falls (ebbs) and tidal currents are to the northwest. The flow close to the seafloor at this location appears to be in the opposite direction. The near-surface currents caused by the flood tide at the western side of the bay at the CRAMP site flow to the southeast; current speeds are slower than those observed when the tide falls and tidal currents are to the northwest. Nearbottom flow at this location also appears to be in the opposite direction. Overall, the tidal currents were faster but less consistent in the alongshore direction at the CRAMP site than along the Wall. The waves were relatively small during both summers and primarily driven by the northeast trade winds. Both waves and currents, and the resulting seabed shear stresses, were more energetic in the western and southern portions of the bay that are more exposed to the trade winds, resulting in little to no fine-grained sediment accumulation in these areas. More than 90\% of the time the wave- and current-induced seabed shear stresses along the Wall during both summer deployments were so low that the fine-grained terrestrial sediment discharged from the

\footnotetext{
${ }^{1}$ USGS Pacific Science Center, 400 Natural Bridges Dr., Santa Cruz, CA 95060
} 
Hanalei River during the previous winters' floods and small summer floods was not able to be mobilized and thus was not transported out of the bay.

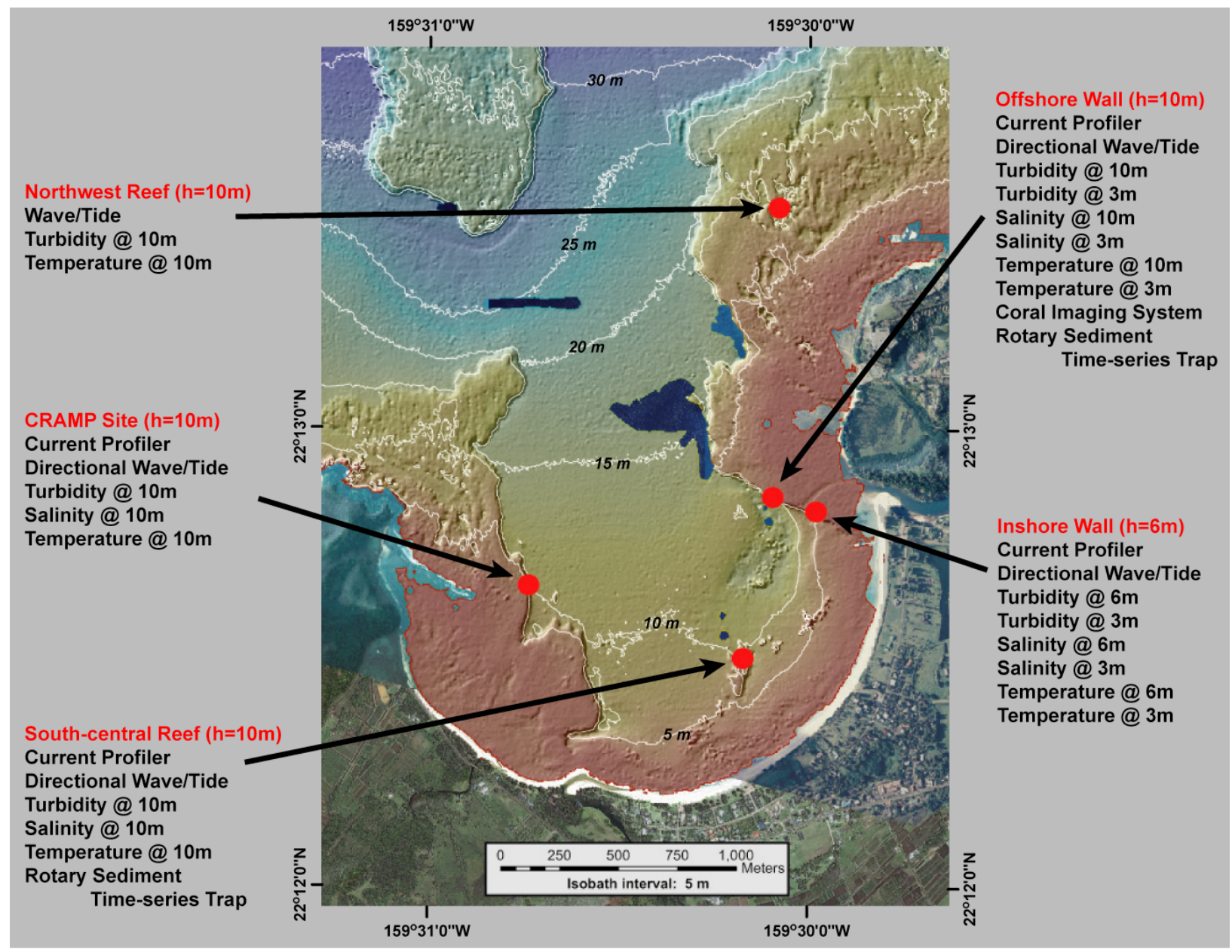

Figure 1. Location and description of the instrument packages employed in the 2006 study. The numbers following the parameters denote the depths of the measurements below the sea surface

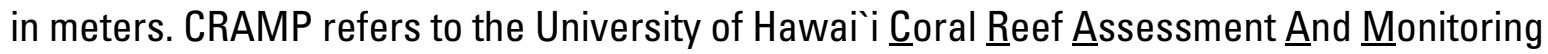
Program. 


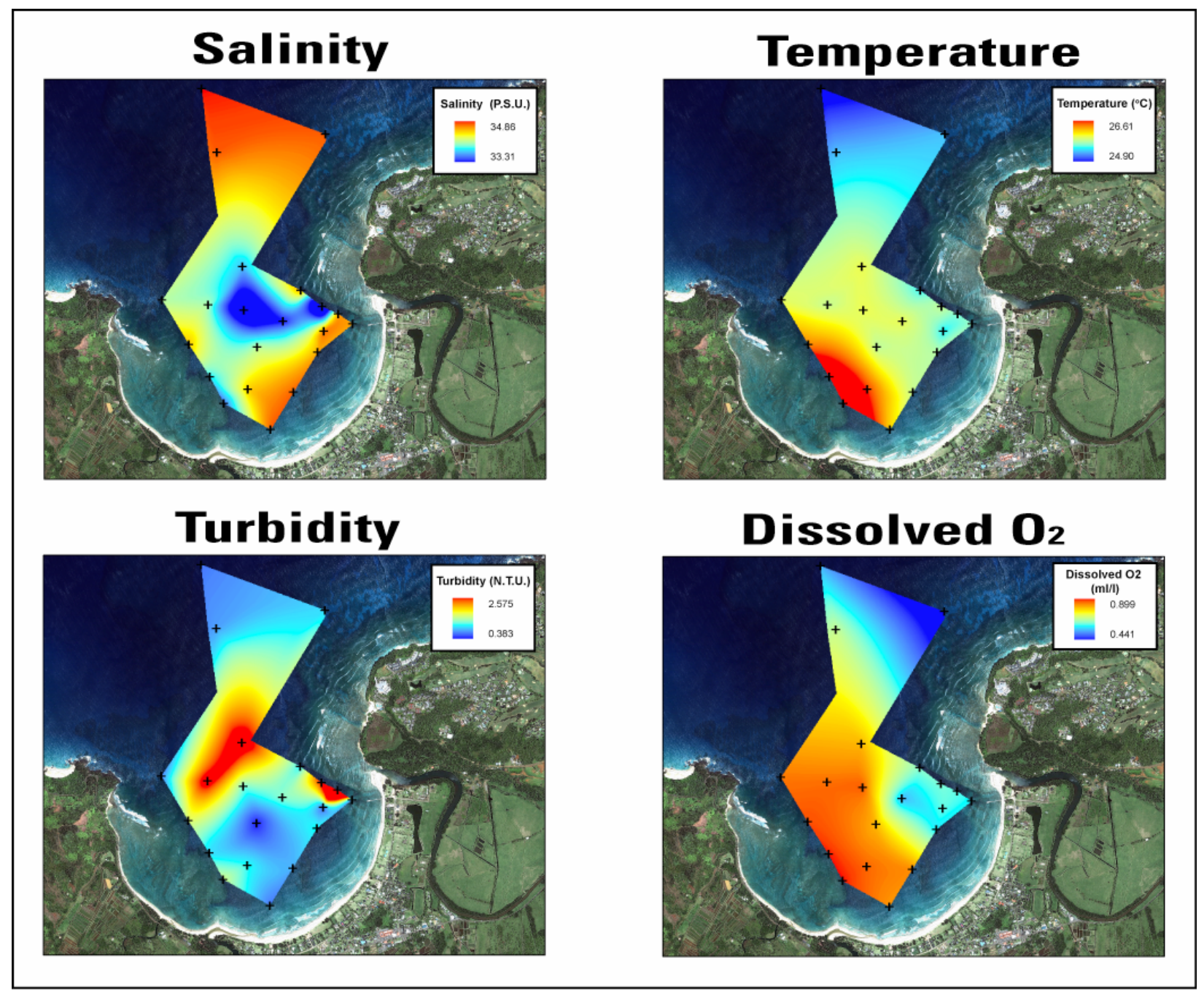

Figure 2. Spatial variability in surface water column properties in June 2006. 


\title{
Streamflow and Suspended Sediment Load in the Hanalei River
}

\author{
Gordon Tribble ${ }^{1}$ and Barry Hill'
}

Streamflow from the upper 18.7 square miles of the Hanalei watershed was measured at a gage operated by the USGS (Station 16103000) during the period 1912-1919, and since 1963. For the period of record, the median daily flow has been 127 cubic feet per second (cfs), and the lowest recorded daily flow was $31 \mathrm{cfs}$ during several days in 1975. The highest recorded daily flow, 7,100 cfs, occurred on Nov. 9, 1995. The highest instantaneous peak flow, 44,600 cfs, occurred on Nov. 3, 1995. Annual peak flows between 1963 and 2006 have averaged 16,310 cfs. Between 1926 and 1993, water was diverted upstream of the gage into the Hanalei Tunnel System, which transported an average of $36 \mathrm{cfs}$ out of the watershed. Since 1993, the median daily flow at the Hanalei River gage has been 133 cfs.

To determine the daily load of suspended sediment, understand patterns of sedimentation, and provide data for the calculation of numerical models, the USGS operated an automated sampler at the Hanalei River gage from October 1, 2003 to September 30, 2006. Sediment samplers were collected at regular timed intervals and more frequently during periods of high flow.

For the three-year period of operation, the total computed load of suspended sediment was 78,061 tons. The median daily load was 2.1 tons, whereas the highest daily load was 14,003 tons (Feb. 21, 2006). Sediment loading was very episodic. Half of the total load occurred during 6 days (out of 1,096) from different storms. Two-thirds of the total load occurred during 13 days during the three-year measurement period; each of those days had a suspended sediment load of more than 1,000 tons. The cumulative load as a function of time is shown in the figure below.

The movement of sediment is driven by rain that subsequently enters the Hanalei River. Of the 13 days with the highest sediment load, 11 were among the 13 with the highest daily streamflow. For the 73 days that contributed $90 \%$ of the cumulative load during the 3 -year period, the correlation coefficient between daily streamflow and daily load was 0.81 .

Rainfall data the site of the stream gage (USGS Station 221101159280801) and at the summit of Mt. Waialeale (the top of the Hanalei watershed, USGS Station 220427159300201) are poorly correlated with the suspended sediment load. For the 73 days that contributed $90 \%$ of the cumulative load during the 3 -year period, the correlation coefficient between rainfall at the Hanalei rain gage and daily load was 0.52 . For the same days, the correlation coefficient between rainfall at the Waialeale rain gage and daily load was 0.44 . To develop an effective numerical relation between sediment load and both rainfall and streamflow, it is probably necessary to use a watershed model that simulates the mechanisms of erosion and sediment transport in the Hanalei watershed.

\footnotetext{
${ }^{1}$ USGS Pacific Islands Water Science Center, 677 Ala Moana Blvd., Ste. 415, Honolulu, HI 96813
} 


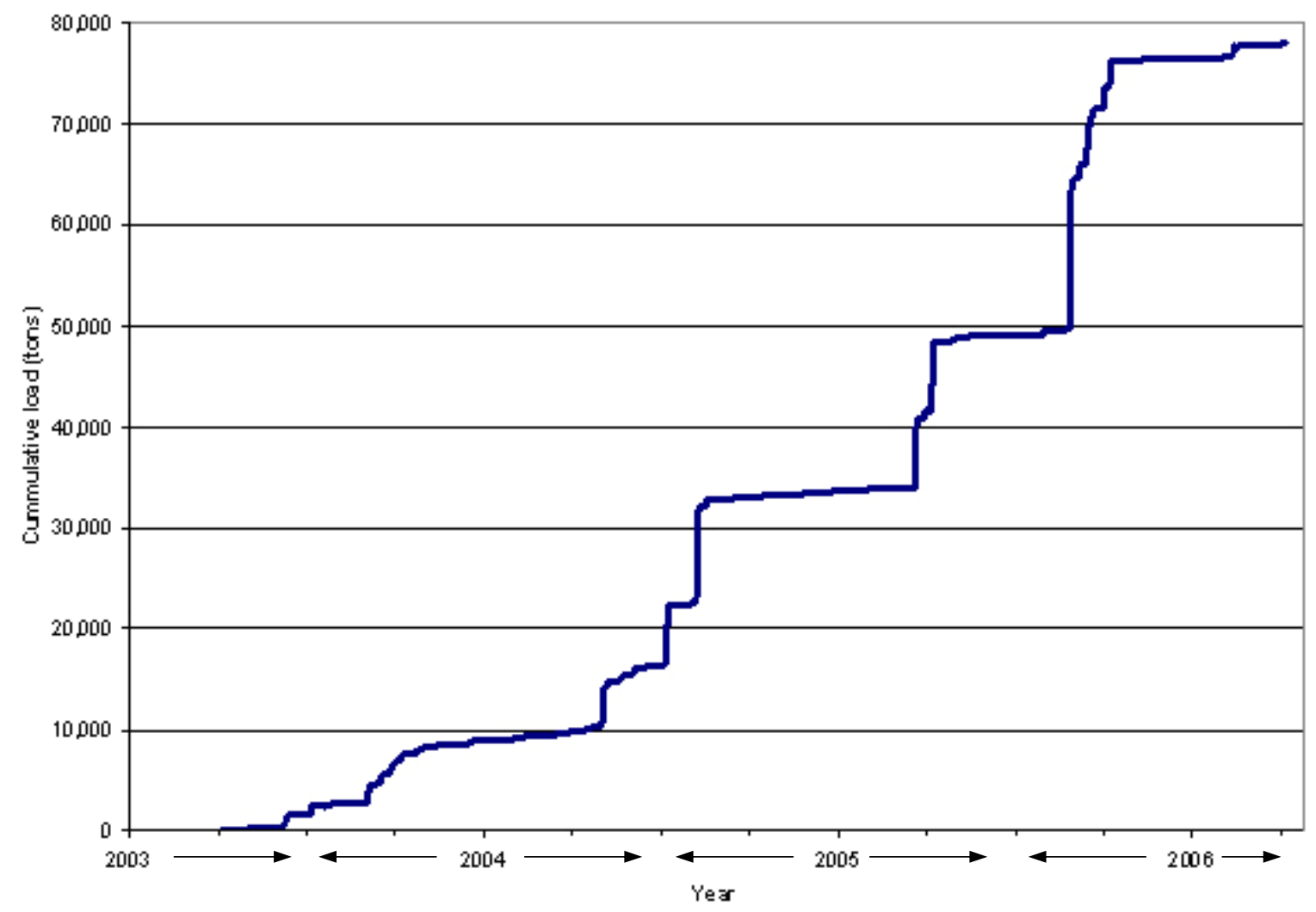

The record of sediment load is based on 912 water samples collected during the threeyear period. The concentrations of suspended sediment in the samples ranged from less than 1 $\mathrm{mg} / \mathrm{L}$ to $2,750 \mathrm{mg} / \mathrm{L}$ on June 21,2005 . Streamflow at the time of this maximum concentration was 14,100 cfs. Streamflow at the collection time of the sample with the highest sediment concentration was close to the highest peak during the whole period of sediment sampling $(15,300 \mathrm{cfs})$ and close to the average annual peak flow at this site $(16,310 \mathrm{cfs})$. However, significantly higher peaks (up to 44,600 cfs) have been recorded during the operation of the Hanalei stream gage. The correlation between instantaneous streamflow and measured suspended sediment concentration for the 912 samples was 0.86 (see figure below). 


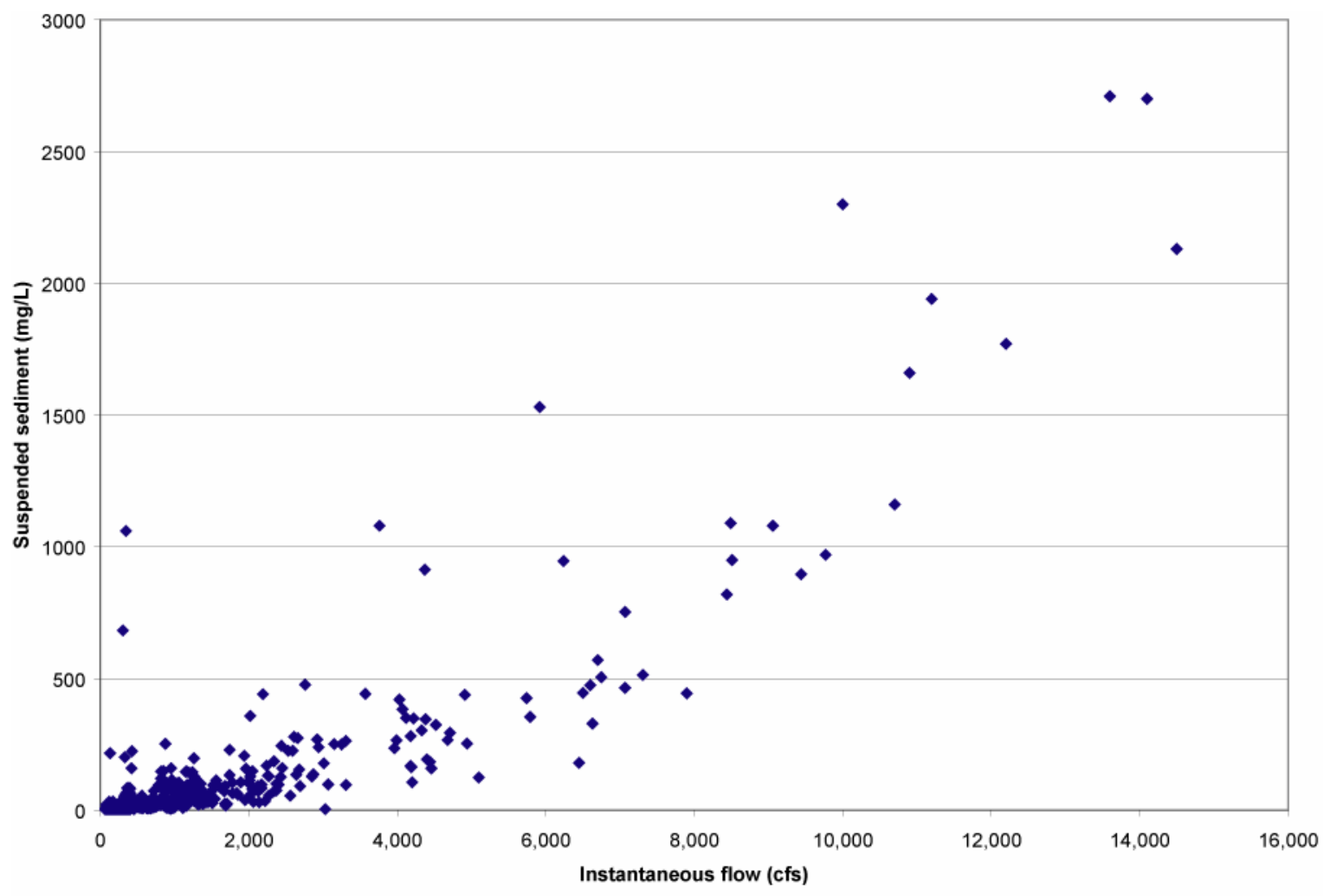




\section{Appendix 1. Agenda for the Hanalei Watershed Workshop}

\section{Wednesday, February 21, 2007}

Princeville Resort, Queen Emma Room

8:00 am Check-In

8:30 am Introduction

Welcome by Maka`ala Kaaumoana, Executive Director, Hanalei Watershed Hui

Hawaiian Pule by Stacy Sproat-Beck

Opening Remarks by Carl Berg and Mike Field

8:45 am Morning Discussion Sessions

Session 1: How sediment is generated in the watershed Moderator: Carl Berg Presenters: Jim Jacobi, Pat Chavez, Ron Bingner/Fred Theurer, Paul Pedone, Ali Fares, Chris Smith/Katina Hanson, and Matt Rosener

10:00 am Short Break

Session 2: How sediment is transported in the watershed Moderator: Mike Field

Presenters: Ron Bingner/Fred Theurer, Pat Chavez, and Gordon Tribble

12:00 pm Lunch

1:30 pm Afternoon Discussion Sessions

Session 3: Deposition of sediment in the lower watershed

Moderator: Gordon Tribble

Presenters: Mike Field

3:00 pm Short Break

Session 4: Deposition of sediment in the Bay and beyond Moderator: Paul Jokiel

Presenters: Mike Bothner, Rich Reynolds, Amy Draut/Mike Bothner, Mike Field, Curt Storlazzi, and Ron Hoeke

5:00 pm Pau Hana Gathering, Hanalei Pavilion Beach Park 


\section{Thursday, February 22, 2007}

\section{Princeville Resort, Queen Emma Room}

\section{8:30 am Morning Discussion Sessions}

Session 5: Flow of nutrients and pathogens via groundwater and surface flow

Moderator: Audrey Shileikis

Presenters: Karen Knee, Ron Bingner/Fred Theurer, Scott Carr, Carl Orazio, Dave Penn/Andrew Parker, and Carl Evensen

10:00 am Short Break

Session 6: How terrestrial and aquatic ecosystems have been affected Moderator: Jim Jacobi

Presenters: Paul Jokiel, Jim Jacobi, Greta Aeby, Eric Brown/Carl Berg, Alan Friedlander/Carl Berg, and Linda Koch

With additional comments by: Fred Theurer and Laetitia Hédouin

12:00 pm Lunch

1:30 pm Afternoon Discussion Sessions

Wrap-up of Sessions 1 through 6

3:00 pm Short Break

Session 7: What management actions are needed to improve water quality and reduce pollution threats to corals?

Moderators: Wendy Wiltse

Presenters: Kathy Chaston, Dave Penn, and Audrey Shileikas

Group discussion and comments on management issues

4:30 pm Closing Discussion and Comments: Mike Field and Carl Berg

5:00 pm Pau 


\section{Appendix 2. List of Workshop Contributors}

\begin{tabular}{|c|c|c|c|}
\hline NAME & ORANIZATION & LOCATION & EMAIL \\
\hline Aeby, Greta & UH-HIMB & $\mathrm{HI}$ & greta@hawaii.edu \\
\hline Ambagis, Steve & UH-HSCU Hilo & $\mathrm{HI}$ & sambagis@usgs.gov \\
\hline Bacon, Scott & Princeville Hotel & $\mathrm{HI}$ & jscottbacon@hawaiiantel.net \\
\hline Berg, Carl & Hanalei Watershed Hui & $\mathrm{HI}$ & cberg@pixi.com \\
\hline Bingner, Ronald & USDA-ARS & Oxford, MS & rbingner@msa-oxford.ars.usda.gov \\
\hline Boehm, Alexandra & Stanford University & Palo Alto, CA & aboehm@stanford.edu \\
\hline Bothner, Mike & USGS-CMG & Woods Hole, MA & mbothner@usgs.gov \\
\hline Brown, Eric & NPS & Kalaupapa, HI & Eric_Brown@nps.gov \\
\hline Carr, Scott & USGS-CERC & Corpus Christi, TX & Scott.Carr@tamucc.edu \\
\hline Carter, Jamie & NOAA-PCSC & $\mathrm{HI}$ & Jamie.Carter@noaa.gov \\
\hline Chaston, Kathy & $\mathrm{UH}$ & $\mathrm{HI}$ & chaston@ hawaii.edu \\
\hline Chavez, Pat & USGS-GEO & Flagstaff, AZ & pchavez@usgs.gov \\
\hline Cochran, Susan & USGS-CMG & Santa Cruz, CA & scochran@usgs.gov \\
\hline de Buhr, Evelyn & Hanalei Watershed Hui & $\mathrm{HI}$ & fdredb@hawaiian.net \\
\hline Draut, Amy & USGS-CMG & Santa Cruz, CA & adraut@usgs.gov \\
\hline Dyda, Rachael & Stanford University & Palo Alto, CA & rydyda@pangea.stanford.edu \\
\hline El-Kadi, Aly & UH-NREM & $\mathrm{HI}$ & aly@ soest.hawaii.edu \\
\hline Evensen, Carl & UH-NREM & $\mathrm{HI}$ & evensen@hawaii.edu \\
\hline Fares, Ali & UH-NREM & $\mathrm{HI}$ & afares@hawaii.edu \\
\hline Field, Michael & USGS-CMG & Santa Cruz, CA & mfield@usgs.gov \\
\hline Friedlander, Alan & NOAA-NOS & HI & afriedlander@oceanicinstitute.org \\
\hline Hanson, Katina & USDA-NRCS & $\mathrm{HI}$ & katina.hanson@hi.usda.gov \\
\hline Hawkes, Mike & FWS & $\mathrm{HI}$ & mike_hawkes@fws.gov \\
\hline Hédouin, Laetita & $\mathrm{UH}$ & $\mathrm{HI}$ & laetitia@hawaii.edu \\
\hline Hill, Barry & USGS-WRD & $\mathrm{HI}$ & brhill@usgs.gov \\
\hline Hoeke, Ron & NOAA-CRED & $\mathrm{HI}$ & ronald.hoeke@noaa.gov \\
\hline Imparato, Carl & Hanalei Watershed Hui & $\mathrm{HI}$ & Carl.Imparato@juno.com \\
\hline Jacobi, Jim & USGS-BRD & $\mathrm{HI}$ & jim_jacobi@usgs.gov \\
\hline Jokiel, Paul & UH-HIMB CRAMP & $\mathrm{HI}$ & jokiel@hawaii.edu \\
\hline Kaaumoana, Maka`ala & Hanalei Watershed Hui & $\mathrm{HI}$ & makaala@hawaiian.net \\
\hline Knee, Karen & Stanford University & Palo Alto, CA & klknee@gmail.com \\
\hline
\end{tabular}


NAME

Koch, Linda

Kubo, Dudley

MacGowan, Petra

Marrin, West

Michaud, Jene

Mikuni, Alan

Minton, Dwayne

Mira, Monika

Mitchell, Mike

Moore, Dan

Nipper, Marion

Okubo, Watson

Orazio, Carl

Parker, Andrew

Paytan, Adina

Pedone, Paul

Penn, David

Quan, Quan

Reynolds, Richard

Riggle, Lex

Ritchie, Jerry

Rodgers, Ku`ulei

Rosener, Matt

Rubin, Dave

Shileikis, Audrey

Shipp, Allison

Slay, Hudson

Smith, Chris

Smith, Gordon

Stock, Jon

Storlazzi, Curt

Street, Joseph

Theurer, Fred

Tribble, Gordon
ORANIZATION

LOCATION

DOH-EHA TMDL

USDA-NRCS

HI

DAR-NOAA Coral Fellow HI

Surfrider

HI

UH-Hilo

HI

USGS-GEOG

FWS

Menlo Park, CA

HI

East HI Soil and Cons. HI

FWS

HI

USDA-NRCS

Texas A\&M

$\mathrm{DOH}$

USGS-CERC

Tetra Tech

Stanford University

USDA-NRCS

DOH-EHA TMDL

USDA-NRCS

USGS-GD

USDA-NRCS

USDA-ARS

University of Hawai i

Hanalei Watershed Hui

USGS-CMG

EPA

USGS-Western Region

$\mathrm{DOH}$

USDA-NRCS

FWS

USGS-ESP

USGS-CMG

Stanford University

USDA-NRCS

USGS-WRD
Portland, OR

Corpus Christi, TX

HI

Columbia, MO

VA

Palo Alto, CA

Portland, OR

HI

Beltsville, MD

Boulder, Co

HI

Beltsville, MD

HI

HI

Santa Cruz, CA

San Francisco, CA

Klamath Falls, OR

HI

HI

$\mathrm{HI}$

Menlo Park, CA

Santa Cruz, CA

Palo Alto, CA

Gaithersburg, MD

HI
EMAIL

linda.koch@doh.hawaii.gov

dudley.kubo@hi.usda.gov

Petra.MacGowan@hawaii.gov

marrin@watersciences.org

jene@hawaii.edu

amikuni@usgs.gov

Dwayne_Minton@fws.gov

monika.mira@hi.nacdnet.net

Mike_Mitchell@fws.gov

Dan.Moore@por.usda.gov

Marion.Nipper@tamucc.edu

watson.okubo@doh.hawaii.gov

corazio@usgs.gov

andrew.parker@tetratech-ffx.com

apaytan@pangea.stanford.edu

Paul.Pedone@or.usda.gov

david.penn@doh.hawaii.gov

quan.quan@wdc.usda.gov

rreynolds@usgs.gov

Lex.Riggle@hi.usda.gov

jerry.ritchie@ars.usda.gov

kuuleir@hawaii.edu

laminarmatt@hawaiiantel.net

drubin@usgs.gov

shileikis.audrey@epa.gov

aashipp@usgs.gov

Hudson.slay@doh.hawaii.gov

chris.smith@hi.usda.gov

Gordon_Smith@fws.gov

jstock@usgs.gov

cstorlazzi@usgs.gov

jstreet@stanford.edu

fred.theurer@verizon.net

gtribble@usgs.gov 


\begin{tabular}{llll}
\multicolumn{1}{c}{ NAME } & \multicolumn{1}{c}{ ORANIZATION } & \multicolumn{1}{c}{ LOCATION } & \multicolumn{1}{c}{ EMAIL } \\
Ueunten, Gary & DOH & HI & gary.ueunten@doh.hawaii.gov \\
Webb, Leah & FWS & HI & Leah_Webb@fws.gov \\
Wiltse, Wendy & EPA & HI & Wiltse.Wendy@epamail.epa.gov \\
Yates, Lindsay & NOAA-NMFS & HI & Lindsay.Yates@noaa.gov \\
Zaun, Brenda & FWS & HI & Brenda_Zaun@fws.gov
\end{tabular}

